PETER L. STRAUSS

\title{
ON RESEGREGATING THE WORLDS OF STATUTE AND COMMON LAW
}

Qui tacet, consentire videtur ${ }^{1}$

\section{Introduction-The Gottshall Case}

In the early afternoon of a humid, 97 degree summer day, James Gottshall was part of a crew of mostly 50- to 60-year-old men replacing track for Conrail. Michael Norvick, the crew supervisor, pressed the men to finish the work. He discouraged observance of the scheduled breaks. Richard Johns collapsed in the heat; Norvick ordered the men back to work as soon as a cold compress had revived him. Five minutes later Johns collapsed again, the victim of a heart attack. Gottshall began 40 minutes of ultimately fruitless cardiopulmonary resuscitation on Johns, his friend for 15 years. Norvick was unable to radio for assistance because Conrail was repairing that part of its communications system; by the time he could drive for help, Johns was dead. Norvick made the men work in sight of his body, which lay covered with a sheet to await the coroner. The next day, Gottshall alleged, Norvick reprimanded Gottshall for his efforts to revive Johns, and-in the same heat and humidity - pushed the crew even harder, with three or four

Peter L. Strauss is Betts Professor of Law, Columbia University.

AuthoR's NOTE: Beyond the usual debts an author owes to colleagues for work developed in their midst are those I have to John Manning and Richard Pierce. Thanks are also owing to Christopher Cross for research help and to the Rockefeller Foundation, whose generosity in providing four weeks' time at their Bellagio Study and Conference Center, in the midst of humanists and far from Lexis and Westlaw, provided unparalleled opportunities for reflection on this paper.

${ }^{1}$ United States v Irvine, 114 S Ct 1473, 1483 (1994) (Scalia concurring).

(C) 1995 by the University of Chicago. All rights reserved.

$0-226-36178-0 / 95 / 1994-0008 \$ 0.200$ 
hours of overtime. Within a few days Gottshall was hospitalized, suffering major depression and post-traumatic stress disorder; he continued to need treatment after his release three weeks later. He sued Conrail under the Federal Employers' Liability Act of $1908,{ }^{2}$ asserting that his condition was caused by its negligent infliction of emotional distress-both through Norvick's actions, and through Conrail's failure to maintain operative communications links with the work party.

FELA, like many state statutes of its time, sought to mitigate the rigor of the existing common law remedies for workplace injuries. Its general thrust was to create a federal tort remedy for railroad workers injured by their employers' negligence, under rules that significantly limited the common law defenses employers could otherwise use. While injured workers still had to show negligence, their employers could claim neither assumption of the risk nor the fellow servant defense; contributory negligence served only to reduce proportionately, not to eliminate, a worker's claim. The statute left the federal courts responsible to develop the contours of this negligence recovery. FELA neither named nor precluded "negligent infliction of emotional distress" as a cause of action. Although the Supreme Court had not had to decide whether it was available before Gottshall sued, in 1987 it had noted both that question and the fact-dependency of any answer to it. ${ }^{3}$

During the years before FELA, state courts had given grudging readings to statutes that sought directly to modify common law tort doctrine on injured workers' behalf. (In reaction, state reform statutes at this time predominantly took the form of worker compensation laws whose implementation was assigned to a new competitor with the courts, the administrative agency.) $)^{4}$ That state court approach reflected what Roscoe Pound, writing in the same year FELA was enacted, characterized as "the orthodox common law attitude towards [a] legislative innovation[]"- to "give to it a strict and narrow interpretation, holding it down rigidly to those cases which it covers expressly." Although he thought the better

\footnotetext{
235 Stat 65, as amended, 45 USC $\$$ 51-60.

${ }^{3}$ Atchison T. \& S.F. R. Co. v Buell, 480 US 557, 568-70 (1987).

${ }^{+}$Louis Jaffe and Nathaniel Nathanson, Administrative Law: Cases and Materials 133-36 (1961).

${ }^{5}$ Roscoe Pound, Common Law and Legislation, 21 Harv L Rev 383, 385 (1908).
} 
courts were already tending to give statutes "a liberal interpretation to cover the whole field [they were] intended to cover," he hoped for the day when a statute would be treated, as well, as a source of policy for courts' analogical reasoning; they should, he believed, receive a statute "fully into the body of the law as affording not only a rule to be applied but a principle from which to reason, and hold it, as a later and more direct expression of the general will, of superior authority to judge-made rules on the same general subject." ${ }^{\prime 6}$ The judicial attitude he decried, we now associate with the general hostility to legislative (i.e., political) change captured by the metaphor of Lochner $v$ New York. ${ }^{7}$ It would take the New Deal Court to put his more cooperative vision in place; in 1936, Harlan Fiske Stone would evoke "the ideal of a unified system of judgemade and statute law woven into a seamless whole by the processes of adjudication." treat from substantive due process and its constitutional cousins, but also strikingly open attitudes toward statutes and the federal agencies Congress often appointed to administer them.

FELA, a beneficiary of these changing attitudes, was more successful than the initial state statutes had been in generating liberal interpretation. Responding to "the breadth of the statutory language [and] the Act's humanitarian purposes," the courts, led by the Supreme Court, accepted it as a remedy to "be developed and enlarged to meet changing conditions and changing concepts of industry's duty toward its workers." 10 That is, until Gottshall's case and a companion reached the Supreme Court from the Third Circuit. Conrail $v$ Gottshall, ${ }^{11}$ like many of the Court's statutory cases in October Term 1993, suggests a return to the treatment of statutes as commands "to be obeyed grudgingly, by construing [them] narrowly and treating [them] as though [they] did not exist for any purpose[s] other than th[ose] embraced within the strict construction of [their] words"12 - to the formalist orthodoxy identified by Dean Pound.

\footnotetext{
${ }^{6}$ Id.

${ }^{7} 198$ US 45 (1905).

${ }^{8}$ Harlan Fiske Stone, The Common Law in the United States, 50 Harv L Rev 4, 12 (1936).

${ }^{9}$ Urie v Thompson, 337 US 163, 180 (1949).

${ }^{10}$ Kernan v American Dredging Co., 355 US 426, 432 (1958).

1114 S Ct 2396 (1994).

${ }^{12}$ Stone, 50 Harv L Rev at 14 (cited in note 8).
} 
Responding to the Court's 1987 invitation, ${ }^{13}$ the Third Circuit had found "negligent infliction of emotional distress" to be a cause of action under FELA. ${ }^{14}$ It then had to define what that cause of action was, and it considered the three principal tests state courts employ for delimiting compensable emotional harm: the first requires an actual physical impact associated with the claimed emotional harm; the second, that the plaintiff, if not actually touched, nonetheless have been immediately exposed to the danger of physical injury by the defendant's negligent conduct; and the third, that a bystander plaintiff, even if outside the zone of danger (say, watching her children play on the street from behind a secondstory window), was so closely related to and so immediately engaged in observing an incident causing physical harm to another that the defendant could reasonably have foreseen her emotional injury as one direct consequence of its negligence. Since Gottshall's emotional injuries resulted from working conditions remarkable principally for their psychological stress, his chances under any of these tests were remote. Mindful of the interpretations underscoring FELA's generosity and the need for contemporaneous standards, and mindful as well of the somewhat restrictive character of the traditional state tests, the Third Circuit had articulated a fourth test, "whether the factual circumstances . . . provide a threshold assurance that there is a likelihood of genuine and serious emotional injury," ${ }^{15}$ an injury that the defendant could foresee. The facts of Gottshall's case, it concluded, gave the necessary assurance.

Justice Thomas wrote for the Court in reversing the Third Circuit and adopting for FELA use the more liberal of the two causes of action that had been in place in 1908, when Congress had acted. Invoking the remedial purposes of the statute, he easily found that FELA gave a remedy for "negligent infliction of emotional distress"; the problem lay in delimiting permissible actions. No jurisdiction allows recovery for all emotional harms that might be causally linked to negligence, given both the ease with which such injuries might be imagined or even falsified and the frequent remoteness of asserted causation. These factors, together with what

\footnotetext{
${ }^{13}$ Atchison T. \& S.F. R. Co. v Buell, 480 US at 568-70 (cited in note 3).

${ }^{14}$ Gottshall v Conrail, 988 F2d 355 (1993).

${ }^{15}$ Id at 371 .
} 
Justice Thomas concluded was the Third Circuit's failure to respect the common law approaches established in the states, led him to reject that court's approach as too liberal-threatening "essentially infinite" liability and conversion of the railroads into "insurers of the emotional well-being and mental health of their employees." 16 He then turned to choose among the three state common law approaches. "[W]e begin with the state of the common law in 1908, when FELA was enacted." ${ }^{17}$ Only the first two of the three established tests were then in use, and of these the more "progressive ... zone of danger test would have been more consistent than the physical impact test with FELA's broad remedial goals." 18 The bystander test (currently adopted in some form in about half the states) "was not developed until 60 years after FELA's enactment and therefore lacks historical support"; moreover, "in most jurisdictions that adhere to it, this test limits recovery to persons who witness the severe injury or death of a close family member,"19 a circumstance that would rarely arise in the FELA workplace. Since fourteen jurisdictions continue to use the zone of danger test, "current usage only confirms this historical pedigree." 20

In at least two respects, Justice Thomas's opinion is a strikingly limited exercise of what he admits to be a common law judicial function; both will figure in the following pages. First, conceding the Court's formal freedom to choose, Congress's general purpose to create a broadly remedial statute, and the evident ferment and growth in state court development of the emotional distress remedy, his opinion takes a static view of what his choices were. He begins and virtually ends with the choices Congress would have had in 1908, had it focused on this question and the then content of the common law. As Justice Ginsburg's dissent for herself and Justices Stevens and Blackmun is at pains to point out, the intervening eight and one-half decades had generally been characterized by liberal judicial construction to protect railroad workers, a remedy that "would be developed and enlarged to meet changing conditions and changing concepts of industry's duty toward its

\footnotetext{
${ }^{16} 114$ S Ct 2396, 2409 (1994).

${ }^{17}$ Id at 2410 .

${ }^{18} \mathrm{Id}$.

${ }^{19}$ Id at 2411.

${ }^{20}$ Id at 2410.
} 
workers." ${ }^{21}$ Causation requirements had been relaxed, negligence enlarged, liability for industrial accidents extended without difficulty into liability for negligently caused occupational disease ${ }^{22}-$ all as a widely remarked element of the Court's jurisprudence that attracted no correcting response from Congress. Rather than continue this line of development, focused on the hazards of work in the instrumentalities of interstate and foreign commerce, the majority tied itself to general common law doctrine as it had been developing in the states. Nor did it consider the most progressive aspects of that evolving remedy; rather, it privileged those elements of doctrine that could have been known to the enacting Congress. This is not a case in which the meaning of statutory text ("negligence") might be played off against legislative history or other contextual data from the time of enactment pointing in some other direction. The issue is understanding "negligence" in 1994, and the majority's conclusion appears to be that it should be guided by the common law choices available in 1908 .

Justice Souter wrote a one-paragraph concurrence expressing for himself alone the view that the majority was choosing the appropriate contemporary rule under "the evolving common law," a choice he found "well within the discretion left to the federal courts under FELA." 23 Indeed, reading the majority opinion in isolation from the rest of the Term's work, one might be tempted to find its reasoning from what Congress might have chosen in 1908 more clumsy than portentious. Or perhaps one might say that it reflects a contemporary resistance to expansive tort liability that is not to be found only among some Justices of the United States Supreme Court. But a review of the rest of the Term's work reveals this element of Gottshall as part of a pattern of hostility to congressional output that threatens to return us to 1908 in more senses than one. Not every decision, but too many, suggest that we have entered a period of Supreme Court uncooperativeness with Congress and resistance to learning from statutes not seen since the early $1930 \mathrm{~s}$. Accretive change and integration of law, so characteristic of common law courts, seem no longer to be federal judges' responsibilities in dealing with statutes. The apparent rejection of Chief Justice

\footnotetext{
${ }^{21}$ Id at 2412, quoting Kernan v American Dredging Co., 355 US 426, 432 (1958).

${ }^{22}$ Urie $v$ Thompson, 337 US 163 (1949).

${ }^{23} 114 \mathrm{~S} \mathrm{Ct}$ at 2412 (Souter, J, concurring).
} 
Stone's coherence-building ideal for the federal judiciary suggests a remarkably weak, even irresponsible, vision for the federal courts. Combined with a somewhat rigid and time-bound textualism, it is also a profoundly destabilizing vision. That is the burden of the remaining pages.

This point may be sharpened, in relation to Gottshall, by contrasting a 1988 opinion of the Court, Monessen Soutbwestern R. Co. $v$ Morgan ${ }^{24}$ that the majority identified as a precedent for its approach. In Monessen, the Court had reversed a lower court award of prejudgment interest to a FELA plaintiff. It had observed, in part, that recovery of prejudgment interest was generally barred in common law actions in 1908, when FELA was enacted; and it had reasoned, seeing the sweeping changes made in other remedies at the time, that this "well-established doctrine" was one that Congress had left intact. Yet the thrust of Monessen was that granting prejudgment interest would have unjustifiable implications for federal remedies generally. The courts had frequently decided against the award of prejudgment interest in intervening years, without congressional interference. Only six years earlier, Congress had considered but not enacted a general provision for prejudgment interest as a part of the Federal Courts Improvement Act of $1982 .{ }^{25}$ Monesson thus was characterized by attention to contemporary legislative-judicial dialogue, existing FELA precedent, and implications for procedural claims; these elements were generally missing in Gottshall. While a dissent had criticized Monesson, too, for its failure fully to realize the remedial purposes of FELA, the Monesson majority voiced no commitment to take the common law as of the statute's enactment in 1908; rather its judgment was that the remedy Congress failed to give in 1908, Congress had affirmatively decided not to give in 1982. In Gottshall, Congress's only discernible signal in 1908 was a delegation to the courts to develop common law ideas of negligence to secure broadly remedial ends; and in the intervening decades Congress had stood quietly by while the courts aggressively pursued that mandate. Thus, along the principal dimension of interest here, the two cases stand in sharp contrast.

The second respect in which Justice Thomas's opinion takes a

\footnotetext{
${ }^{24} 486$ US 330 (1988).

${ }^{25}$ Pub L 97-164, 96 Stat 25. See 486 US at 339 n 8, also citing the explanation of the omission at S Rep No 97-275, pp 11-12 (1981).
} 
limited view of federal court common law function is perhaps more subtle, but also worth noting in an introductory way; it too will recur. Recall that in rejecting the widely adopted bystander test, he argued in part that "in most jurisdictions that adhere to it, this test limits recovery to persons who witness the severe injury or death of a close family member." If this aspect of the test were binding upon the Court, that might be an ahistorical reason for rejecting it. But what "most" state jurisdictions do would be binding on the Court only if the Court itself lacks common law authority to adapt that element to the workplace for FELA's federal purposes. It does not seem that Justice Thomas is reinvoking the "natural" common law of Holmes's "brooding omnipresence in the sky"; ${ }^{26}$ the Court can choose, on federal principles, from among the several possibilities that state common law resolutions offer. The hidden premise seems to be, however, that unlike state courts, the Supreme Court cannot properly make its own test. It is as if Congress's delegation to the federal courts to develop common law remedies for railroad worker injuries conveyed or recognized far less judicial authority than a state common law court would have-an authority necessarily dependent on what the state courts were doing. In this respect, the Supreme Court (and by implication the other federal courts) is not a common law court even when it operates under delegated authority to fill gaps in federal law, under what is undoubtedly the federal question jurisdiction. That would be a strikingly limited view of the federal judicial function.

\section{INTEGRATION AND INTERPRETATION}

The focus of this article is the issue of integrating statutory and other law. A sustantial number of statutory cases decided during October Term 1993 offered the Court a choice between treating statutes as static, isolated instructions from higher authority, and regarding them as part of a "unified system of judge-made and statute law." ${ }^{27}$ It tended to make the former choice, one that segregates statutes from the common law. The argument here is that, in the process, it diminishes both statute and common law, both legislature and court. Integrating statutes and common law has the

\footnotetext{
${ }^{26}$ See note 114 .

${ }^{27}$ Stone, text at note 8 .
} 
opposite effect. Legislative influence and statutes are extended when statutory policy becomes the basis for analogical reasoning to decide cases that have not been provided for. The judicial function is also augmented if the world in which judges act to promote coherence includes statutory as well as judge-made law. Thus, to include statutes implies that judges may shape their readings within the possibilities offered by the text, over time, as changing general law and the social circumstances to which it responds may suggest.

The contrast between legislation as static judgment, and legislation as an element in the continuing evolution of law's fabric, is strongly rooted in my own specialty in administrative law. One characteristic of administrative law, so intuitive that we easily lose sight of it, is that it is administered law - that we expect its dimensions constantly to change. Administrative agencies are continuing bodies with proactive responsibilities, acting under the oversight of the political branches as well as the judiciary. We anticipate that they will change course; they are in effect the preferred managers of change. In the communities they influence, their administration produces expectations about what is permissible that vary across time. Congress is watching and the President is watching; the emerging solutions frame community understandings to be generally acted upon, and can come to be taken as the governing law. In these respects, integrative approaches are of the essence. Whatever else, the agency, in its context, will not have encountered issues of statutory meaning freed of considerations of purpose, politics, or contemporary understandings. For those subject to or interested in the agency's work, one may be reasonably sure the situation is the same. Congress's continuing oversight assures that it legislates in the context of existing judicial and agency "law," as well as its own prior work. Similarly, agencies act in a context framed by statute and case law; and the judiciary, too, proceeds under the premise of mutual responsibility for the development of law.

The static view of statutory law is in sharp contrast. Its premise is that the elements of government work sporadically and in isolation from one another. At the beginning of this century, premises like these found expression in the idea that legislative actions in derogation of the common law were to be narrowly construed; that is, since the common law was an area for judicial responsibility, 
the legislature really shouldn't intrude, and if it tried to do so its actions should be given minimal impact. In many of the cases that concern this essay, the premise seems to be the obverse-where Congress has acted, it has (sole) responsibility for the elucidation of policy, and the only appropriate role of courts is to apply the policies enacted by the acting Congress, whose dimensions properly change only when Congress chooses to act again. Or, Congress may have delegated to an agency some authority to give shape to statutory language; if a court using standard tools of statutory interpretation is unable to determine what the language means, it must accept the agency's view. But in deciding in the first instance what the statutory language might mean, the court will look only to its own resources; for judges who are also formalists, those resources do not include the understandings reached by others, such as the agency initially responsible for the statute's implementation.

One way to characterize these competing views might be in terms of how they understand congressional silence. One takes from that silence implicit consent; the other understands that the burden of seeking new law has not been met by those who might propose it. ${ }^{28}$ In a complex world characterized on all sides by information overload and large impersonal organizations that both generate information and attempt to deal with it, one would be foolish to claim that either view completely captured institutional reality. Congress is a bureaucracy of tens of thousands, and too frequently acts on legislative behemoths no member can have read; the claim that it "knows" anything is absurd. But so, too, is any claim that its actions are wholly independent of the expectations about law, however imperfect, generated by the work of courts and agencies. Legislation, including amendments to existing laws, responds to current problems. While the absence of problems makes it unlikely Congress will pass new laws, that absence hardly indicates that "law" is missing; most social conduct occurs in the shadow of already established expectations about what existing law requires or permits.

This way of understanding the choice might suggest that each

\footnotetext{
${ }^{28}$ Compare Barry K. Weingast and Mark J. Moran, Bureaucratic Discretion or Congressional Control? Regulatory Policymaking by the Federal Trade Commission, $91 \mathrm{~J}$ Pol Economics 765 (1983), making a similar point about "bureaucratic" and "congressional dominance" theories of the relationships between agencies and their congressional committees.
} 
is inherently political - the integrative view likely to be favored by judges (and others) believing in law and expansive government, the static view by those who are more skeptical of the desirability of large government. In the one case, judicial sympathy for previous congressional judgments, expansively treated in the light of current conditions, places the burden of congressional gridlock (the difficulty in securing new legislation) on those who would oppose innovation; in the other, holding Congress to its precise dispositions places the burden of gridlock on those who want innovation. If both positions are inherently political, neither side, a priori, is entitled to the advantage; neither judicial position has greater legitimacy. We may be politically distressed that the Court is in the hands of Justices who are skeptical about government, but cannot claim that their position is any more "political," that is, unjudicial, than the integrative view would be.

That interpretation depends, however, on a crucial premise: that law emerges only as the product of political action, not as the product of (judicial) reason acting within the already extant framework of law, that is, not as "common law." And it also assumes that Congress will always act in the direction of enlarging government. At a given moment, Congress might opt for regulation or for deregulation-indeed, for economic regulation since the 1970s its direction has been predominantly the latter. A court sensitive to that deregulatory trend would be warranted in extending it by analogy, without entailing its own politics. In this way, an integrative approach would produce smaller rather than larger government. Refusing to do so-treating a deregulatory statute as expressing no larger judgment than its explicit terms require-would result in the judiciary leaving more government in place than would follow from its giving that statute larger effect. It is perhaps true that, in general, our explicitly political institutions have been choosing for more rather than less government over the past century; but then building on those judgments can be defended as accepting political outcomes from those authorized to reach them. "Larger government," like "smaller government," is not an inevitable consequence of integrative reasoning with statutes. Dependent on the judgments Congress has been reaching, it reflects legislative rather than judicial politics; the static approach cannot be so described.

Neither choice entails liberating judges from their subordination 
in ordinary law matters to legislative judgment, or resolves the question of what are the appropriate materials of interpretation. The point, well made by Professor Alexander Aleinikoff of Michigan, ${ }^{29}$ can be illustrated by a table:

\begin{tabular}{llc}
\hline \hline & $\begin{array}{c}\text { Statutes are static, always } \\
\text { meaning what was first enacted }\end{array}$ & $\begin{array}{c}\text { Statutes acquire meaning over } \\
\text { time, as social and legal } \\
\text { contexts change }\end{array}$ \\
\hline Formalist & $\begin{array}{c}\text { Only text may be consulted, its } \\
\text { meaning amplified by usages at } \\
\text { the time of enactment }\end{array}$ & $\begin{array}{c}\text { Only text may be consulted, but } \\
\text { contemporary usage and in- } \\
\text { tervening texts may be con- } \\
\text { sidered }\end{array}$ \\
Intentionalist & $\begin{array}{c}\text { Political history, including a vari- } \\
\text { ety of legislative materials, may } \\
\text { be consulted to discover the en- } \\
\text { acting legislature's intents, or, } \\
\text { more broadly, purposes }\end{array}$ & $\begin{array}{c}\text { the court seeks the outcome } \\
\text { that best fits contemporary law }\end{array}$ \\
\hline
\end{tabular}

Thus, either a textualist or an intentionalist may use her preferred tools in the service of giving relatively static meaning to a statute, the one free of any obligation to consider the information that political context provides to interpretation, the other seeking in evidence of purpose and political history the meaning that would probably have been assigned it by the enacting legislature. Both then expect that meaning to remain constant over the ensuing years. While the integrative choice lacks that expectation, it too is dependent on statutory language, and can be made by textualists as well as intentionalists. ${ }^{30}$ In and of itself, it does not authorize a judge simply to disregard a statutory text that she thinks may have outlived its usefulness ${ }^{31}$ or to invent policies of her own preference,

\footnotetext{
${ }^{29}$ T. Alexander Aleinikoff, Updating Statutory Interpretation, 87 Mich L Rev 20 (1988).

${ }^{30} \mathrm{~A}$ striking example is provided by a case once thought to have sounded the death knell of "plain meaning" interpretation, United States v American Trucking Ass'n, 310 US 534 (1940). The Court was divided, 5-4, between New Deal appointees who relied heavily on legislative history materials, and more experienced Justices who found the text controlling. A close reading of the dissent to which the latter subscribed reveals that its principal mechanism lies in understanding that text in a manner that integrates it well with other statutory elements of the law. Indeed, that characteristic is reinforced on seeing that the opinion appears under the signature of Justice Stone, see text at note 8 .

${ }^{31}$ Compare Guido Calabresi, A Common Law for the Age of Statutes (Harvard, 1982); Robert Weisberg, The Calabresian Judicial Artist: Statutes and the New Legal Process, 35 Stan L Rev 213 (1983).
} 
independent of those instinct in existing law. ${ }^{32}$ The cases to be discussed are ones in which alternative understandings of the texts were available, with different results if they were treated as discrete instruments of a particular time, than if they were taken contemporaneously, as part of the evolving fabric of the general law.

Either choice, in particular judicial hands, could generate undesirable consequences for the relationship between the courts and Congress. Static approaches joined with a formal textualism, that limits judicial data to statutory words and disclaims judicial authority to make supplementary judgments, may induce prolix drafting ${ }^{33}$ reduce the likely useful lifespan of legislative judgments, and contribute to continuous friction between Congress and courts. An integrative approach, on the other hand, may weaken Congress's incentives to legislate and may encourage judicial adventurism. A strong belief in separation of powers seems to support the idea that judges should not treat statutes as they do the common law-if judges are not scrupulously attentive to legislative judgments, to do so risks confusing legislative with judicial authority. ${ }^{34}$ Here, the

32 That is, a judge taking an integrative approach may nonetheless regard herself as bound by the various considerations, external to herself and largely of legislative creation, that circumstances require her to integrate. The problem is just that faced by the self-aware common law judge; she is not the initiator of values, but a loyal agent of what she finds in the law as a whole, for whose evolving coherence and "fit" she is constantly responsible. Compare Nicholas S. Zeppos, The Use of Autbority in Statutory Interpretation: An Empirical Analysis, 70 Tex L Rev 1073, 1081-84 (1992), describing "dynamic" theories as if they entailed personal responsibility for such ends as "furthering virtue in the body politic."

33

The British spirit of civil liberty induced the English judges to adhere strictly to the law, to its exact expressions. This again induced the law-makers to be, in their phraseology, as explicit and minute as possible, which causes such a tautology and endless repetition in the statutes of that country that even so eminent a statesman as Sir Robert Peel declared, in parliament, that he "contemplates no task with so much distaste as the reading through an ordinary act of parliament." Men have at length found out that little or nothing is gained by attempting to speak with absolute clearness and endless specifications, but that human speech is the clearer, the less we endeavor to supply by words and specifications that interpretation which common sense must give to human words. However minutely we may define, somewhere we needs must trust at last to common sense and good faith.

Francis Lieber, Legal and Political Hermeneutics 20 (rev 3d ed. 1880). McNollgast, Positive Canons: The Role of Legislative Bargains in Statutory Interpretation, 80 Georgetown L J 705, 716 (1992), argues that "[i]nterpretive canons . . . should aid the legislative process, making it less costly for policy bargains to be struck"; judicial behavior that raises those costs, for example, by forcing the expense of anticipating and countermanding court decisions, is justifiable only on premises that disfavor legislation.

${ }^{34}$ See Thomas W. Merrill, The Common Law Powers of Federal Courts, 52 U Chi L Rev 1, 32-33 (1985). 
revealing contrast may involve gap-filling rather than interpretation in the strict sense-that is, it may involve the willingness of a court to acknowledge cases not provided for by statutes and then use statutory material as a source of analogy to decide them. Unmistakably, permitting analogy from a statute to fill an acknowledged gap is friendlier to legislative authority than refusal; but unmistakably, too, it is the court that draws the analogy, risking judicial adventurism. The result may be to lead judges into a certain lack of candor about whether they are filling gaps, or simply interpreting what they pretend Congress has provided for. ${ }^{35}$

Yet if risks of misuse fall on either side, some characteristics of the legal environment argue strongly for integration: For citizens, law is inevitably an integral system, premised in contemporary social expectations and political judgments; a person interested in her legal obligations looks to the whole environment, not a disordered collection of fragmentary, isolated, mutually independent pieces. Legislation will inevitably be imprecise, requiring both interpretation and gap-filling; pretending otherwise increases its costs. ${ }^{36}$ Courts are better suited than legislatures for the classic common law function of continually inventing coherence out of the materials of the law. With statutes the dominant form of law, and especially as they become more numerous, problems of aging statutory judgment will inevitably arise and need to be resolved

${ }^{35}$ On the importance of candor, see, for example, Nicholas S. Zeppos, Judicial Candor and Statutory Interpretation, 78 Georgetown L J 353 (1989); William N. Eskridge, Jr., and Philip P. Frickey, Statutory Interpretation as Practical Reasoning, 42 Stan L Rev 321 (1990); on its frequent absence, Zeppos, cited in note 32.

${ }^{36}$ The basic reason why statutes are so frequently ambiguous in application is not that they are poorly drafted - though many are-and not that the legislators failed to agree on just what they wanted to accomplish in the statute-though often they do fail-but that a statute necessarily is drafted in advance of, and with imperfect appreciation for the problems that will be encountered in, its application.

Richard Posner, Statutory Interpretation-in the Classroom and in the Courtroom, $50 \mathrm{U}$ Chi L Rev 800, 811 (1983).

[O]nly rarely can statutory language be precise in conveying either policy bargains or instructions to agencies. Nature has a nasty habit of creating situations in which the applicability of a statute is unclear. But even if nature were not unkind, the meaning of statutes would still be problematic because language is inherently imprecise and because rational political actors, having numerous ways to occupy their time, would never devote the effort necessary to minimize the indeterminacy of statutory language.

McNollgast, Legislative Intent: The Use of Positive Political Theory in Statutory Interpretation, 57 L \& Contemp Probs 3, 13 (1994). See also Aleinikoff, 87 Mich L Rev at 25 (cited in note 29). 
before legislative attention can be directed to them. In the long run, finally, successful government must be a cooperative enterprise in its everyday affairs; as the years leading to the New Deal should have taught us, continuous legislative-judicial antagonism over ordinary political judgments is unsustainable. ${ }^{37}$

The explicit argument here, then, is about judicial responsibility-the difference between an integrative approach to legal materials and one that takes statutes as individual, isolated, and static events - and, consequently, about the evolving political dynamic between Congress and the Court. Moreover, the cases, not the literature, are the focus. ${ }^{38}$ These pages are intended more to sketch the Court's work, to explore the factual ground, than to reason to a foundational theory of interpretation. A growing body of literature has plumbed the issues of interpretation in a theoretical way, and the reader probably has already found a good deal of tangency between the views offered here and those of younger scholars characterizing their approaches as "dynamic," "practical," "updating," and the like. ${ }^{39}$ Admiring that work and indebted to it, I have none-

\footnotetext{
37 "Ordinary political judgment" signals a limit here to matters that do not in themselves raise questions of constitutional law-whether liberties of the citizen, or structural arrangements such as underlay invalidation of the legislative veto. In that context, Woodrow Wilson's words have commanding force:

... [G]overnment is not a machine, but a living thing. . . . No living thing can have its organs offset against each other as checks, and live. On the contrary, its life is dependent upon their quick cooperation, their ready response to the commands of instinct or intelligence, their amicable community of purpose. Government is not a body of blind forces; it is a body of men, with highly differentiated function, no doubt, in our modern day of specialization, but with a common task and purpose. Their cooperation is indispensable, their warfare fatal. There can be no successful government without leadership or without the intimate, almost instinctive, coordination of the organs of life and action. This is not theory, but fact, and displays its force as fact, whatever theories may be thrown across its track.
}

Constitutional Government in the United States 56-57 (1908). Wilson's argument may be taken as one about the limits of "separation of powers" or "checks and balances" rather than as an effort completely to refute those constitutionally embedded ideas. The challenge of constitutional government, as Madison described it, is that "you must first enable the government to control the governed; and in the next place oblige it to control itself." Federalist 51 (Madison). Wilson addresses what is required to "control the governed" $-a$ government, one "law." Central to Madison's paradox is the understanding that institutional threats to that capacity are as dangerous to the constitutional ideal as are threats to produce "a gradual contentration of the several powers in the same department." Id.

${ }^{38}$ See also Zeppos, cited in note 32, for a valuable effort to explore the Court's statutory work empirically, over the course of a century; he found few pronounced changes in practice along the dimensions he sought to measure.

${ }^{39}$ For example, William N. Eskridge, Jr., Dynamic Statutory Interpretation, 135 U Pa L Rev 1479 (1987); Philip P. Frickey, Congressional Intent, Practical Reasoning, and the Dynamic 
theless found it more urgent to address the Justices and their work than any academic colleagues. Nonetheless, the discussion will inevitably be caught up to a degree in the raging debates over interpretation, particularly those that concern the competitition between textual and purposive approaches to statutory texts.

Unmistakably, the recent cases enact the Court's preference that statutes be understood, where possible, from the surface meaning of their words, and the reader has sensed my discomfort with the implications of that approach, also, for legislative-judicial conflict. The Court's shift to textualism has been adeptly documented by others ${ }^{40}$ and is well captured in two recently published graphics. Professor Thomas Merrill of Northwestern, for example, gives the following table to illustrate the relative use of legislative history and dictionaries in statutory interpretation cases in 1981, 1988, and 1992:41

Textualism in the Supreme Court, 1981-92

\begin{tabular}{ccccc}
\hline \hline & $\begin{array}{c}\text { Total Statutory } \\
\text { Interpretation } \\
\text { Cases }\end{array}$ & $\begin{array}{c}\text { Cases Making } \\
\text { Substantive } \\
\text { Use of Legis- } \\
\text { lative Hist. }\end{array}$ & $\begin{array}{c}\text { Cases Not } \\
\text { Mentioning } \\
\text { Legislative } \\
\text { History }\end{array}$ & $\begin{array}{c}\text { Cases Relying } \\
\text { on Dictionaries }\end{array}$ \\
\hline $1981 \ldots \ldots \ldots \ldots \ldots$ & 69 & $69(100 \%)$ & $0 \quad(0 \%)$ & $1 \quad(1 \%)$ \\
$1988 \ldots \ldots \ldots \ldots \ldots$ & 71 & $53(75 \%)$ & $10(14 \%)$ & $9(13 \%)$ \\
$1992 \ldots \ldots \ldots \ldots \ldots$ & 66 & $12(18 \%)$ & $41(62 \%)$ & $22(33 \%)$ \\
\hline
\end{tabular}

Nature of Federal Indian Law, 78 Cal L Rev 1137 (1990); Daniel A. Farber, The Inevitability of Practical Reason: Statutes, Formalism and the Rule of Law, 45 Vand L Rev 533 (1992); T. Alexander Aleinikoff, Updating Statutory Interpretation, 87 Mich L Rev 20 (1988); Edward L. Rubin, Law and Legislation in the Administrative State, 89 Colum L Rev 369 (1989); Cass R. Sunstein, Interpreting Statutes in the Regulatory State, 103 Harv L Rev 405 (1989); Zeppos, cited in note 29. Compare, however, note 32 above.

This eruption of materials on the problems of statutory interpretation, dating from the late 1980 's, has been widely noted. As figures central to their development have appropriately recognized, their work is well grounded in the work of intellectual centrists of an earlier time. Farber, 45 Vand L Rev (Karl Llewellyn); William N. Eskridge, Jr., and Philip P. Frickey, The Making of the Legal Process, 107 Harv L Rev 2031 (1994) (Henry M. Hart, Jr., and Albert M. Sacks); see also Edward H. Levi, An Introduction to Legal Reasoning (1948); Stone, cited in note 8; Pound, cited in note 5.

${ }^{40}$ For example, the works cited in note 39. For a contrasting view founded on an optimism about the Court's seeking shared ground, that the sharp division of the past Term's work makes hard to join, see Frederick Schauer, Statutory Construction and the Coordinating Function of Plain Meaning, 1990 Supreme Court Review 231; Professor Merrill, in the work about to be cited in text, persuasively argues that the adamancy of Justices Scalia and Thomas respecting their preferred modes of interpretation may cloak a larger disposition to compromise over such matters on the part of other Justices.

${ }^{41}$ Thomas W. Merrill, Textualism and the Future of the Chevron Doctrine, 72 Wash U L Q 351,355 (1994). 
And a recent student note counts the number of cases referring to dictionaries in each term of Court since 1842: ${ }^{42}$
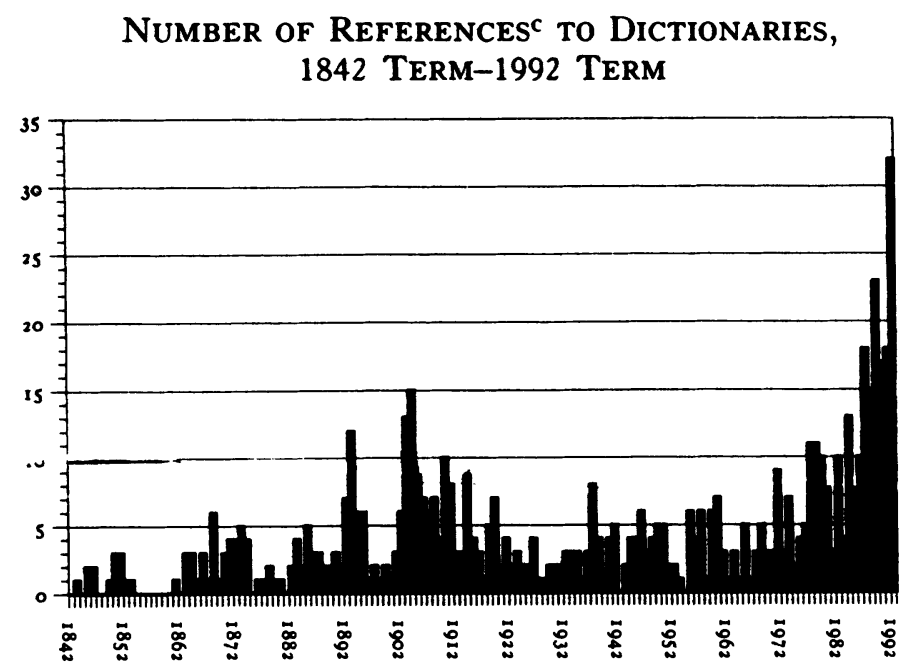

"Includes all cases that use the words "dictionary" or "dictionaries." Search of LEXIS, Genfed library, US file (Jan. 4, 1994).

The past Term's performance was not quite so dramatic in these terms-of forty-three cases that referred to statutory interpretation or meaning in the text of at least one opinion, sixteen also referred to a "dictionary" or "dictionaries," while a slightly larger number contained the term "legislative history." ${ }^{\text {" An }}$ An in a number of cases, some Justices appeared self-conscious about noting the ongoing disputes over the use of legislative history, sometimes narrowing but not disclaiming the appropriateness of their use. ${ }^{44}$

\footnotetext{
${ }^{42}$ Note, Looking It Up: Dictionaries and Statutory Interpretation, 107 Harv L Rev 1437, 1454 (1994).

${ }^{43}$ The initial search of the Lexis Genfed:US database was for "(statut! w/10 (interpret! or mean!)) and Congress! and date(aft 10/1/93)"; it was then modified (for these purposes) by adding "and dictionar!"; the modification "and (dictionar! or defin!" produced $\mathbf{4 0}$ results; "and legislative history," 22; "and (legislat! w/5 (purpose or inten!)," 23. Of this last group of 23 , six occurrences coincided with mentions of both legislative history and dictionaries, two with mentions of dictionaries but not legislative history, 11 with mentions of legislative history but not dictionaries, and four in the absence of either. "Legislative history" and "dictionar!" appeared together in four additional opinions; dictionaries alone, in four opinions; and "legislative history" appears without the other terms in one opinion only.

The presence of a term doesn't show the Court's attitude or use, or whether it appeared in majority or dissent; clearly a more qualitative assessment is called for.

${ }^{44}$ For example, Sbannon v United States, 114 S Ct 2419, discussed at p 471; City of Chicago $v$ Environmental Defense Fund, 114 S Ct 1588, discussed at p 499.
} 
The pages following take up most of the Term's opinions referring to issues of statutory interpretation or meaning, omitting those that did not seem to raise the questions under discussion here. ${ }^{45}$ They begin with the civil and criminal cases in which only the courts and the legislature are prominent as possible sources of meaning, and then turn to cases in which administrative agencies may also have spoken to the problems raised. We will find that, in general, Court majorities did not take seriously the contributions that settled expectations and Congress's role as a continuing legislative body can make to interpretation; their tendency was to take statutes as static events. In this sense, the majorities rejected the common law responsibility for statutes suggested long ago by Stone and others. This phenomenon was particularly striking in the last group of cases, in which Congress has signaled that agencies have primary responsibility for shaping law and, as the result of those responsibilities, agencies will have acquired a natural expertise in the issues that complex statutes present. ${ }^{46}$ Again, the result, in my judgment, has been to recreate an atmosphere of virtual warfare

\footnotetext{
${ }^{45}$ For example, United States $v$ Irvine, 114 S Ct 1473 , from which the epigram is taken, note 1 , was an all but unanimous interpretation of the gift tax statutes and regulations. Justice Scalia stood apart from Justice Souter's opinion for the remainder of the participating court to insist that the dimensions of the "reasonable time" limitation on which all Justices agreed should be derived from text, rather than policy. For the gift-giver in that case, if not for the Congress whose work he regularly assesses, "the failure to make a reasonably prompt disclaimer of a known bequest is an implicit acceptance." Id at 1483. Key Tronic Corp. $v$ United States, 114 S Ct 1960, is characterized by divided opinions on a statutory issue-Justice Stevens writing for the majority and Justice Scalia for Justices Thomas and Blackmun - but does not clearly raise the problem discussed in text. At issue was whether a provision of CERCLA authorized recovery of attorneys' fees incurred by one responsible party who settled its action with EPA, against other responsible parties. Justice Stevens's opinion examines legislative history and judicial developments along with text, while Justice Scalia contents himself with textual analysis alone; but the question is not one as to which there appears to have been any development of a judicial or agency view over time, that could have influenced the shape of the relevant legislative text. In Dalton $v$ Specter, $114 \mathrm{~S}$ Ct 1719, Justice Souter's concurrence for four prefers to ground judgment in a contextual assessment whether Congress meant to preclude review of a Commission's actions under the Defense Base Closure and Realignment Act than in a formal assessment of whether those actions were "final" within the meaning of the Administrative Procedure Act, 5 USC 704, as Chief Justice Rehnquist wrote for the majority. Posters 'n Tbings $v$ United States, 114 S Ct 1747, concerned the issue of scienter under a federal statute prohibiting the sale of drug paraphernalia. All agreed that a scienter element was required to convict of the offense, but Justices Scalia, Kennedy, and Thomas would have defined that element in a manner that would give the prosecution somewhat more latitude in seeking conviction. In none of these cases do the lines developed in the text appear to me to be particularly prominent.

${ }^{46}$ See Richard J. Pierce, Jr., The Supreme Court's New Hypertextualism: An Invitation to Cacophony and Incoberence in the Administrative State, 95 Colum L Rev (forthcoming).
} 
between Congress and Court that we have not witnessed since the first years of the New Deal.

\section{Civil Cases}

\section{A. CONRAIL V GOTTSHALL ${ }^{47}$}

\section{B. HECK V HUMPHREY}

Heck $v$ Humphrey ${ }^{48}$ possibly echoes Gottsball's commitment to common law readings tied to the time a statute is enacted. In this case, nine Justices agreed for varying reasons that, while his conviction remains in effect, a state prisoner has no cause of action for monetary damages under the Civil Rights Act, 42 USC $\S 1983$, for allegedly unconstitutional conviction or imprisonment. In effect, the holding requires prisoners to secure the invalidation of their convictions by other means (such as the federal habeas corpus statute) before a Civil Rights Act cause of action can be maintained. Justice Scalia, for five Justices (the Chief Justice and Justices Kennedy, Thomas, and Ginsburg), grounded that conclusion in a study of the analogous common law cause of action for malicious prosecution, one element of which is "termination of the prior criminal proceeding in favor of the accused." Justice Souter, for Justices Blackmun, Stevens, and O'Connor, preferred to ground the outcome in what he perceived to be the appropriate relationship between $\S 1983$ and the federal habeas corpus statute. Since the habeas statute is specifically directed at issues of legality in state criminal processes and $\S 1983$ is a much more general form of relief, Justice Souter concluded that permitting the $\S 1983$ action prior to an available habeas outcome would frustrate Congress's specific judgment about the manner in which relief from state convictions should be sought in federal courts.

It is striking that the Court's two former state court judges, and the three Justices who we will see most often favored integrative over static-meaning approaches to statutes during the Term, preferred to treat the case as involving the contemporary reconciliation of two federal statutes, rather than the implications for one statute

${ }^{47} 114$ S Ct 2396 (1994); the case is discussed at p 429.

48114 S Ct 2364 (1994). 
( $\$ 1983$ ) of a common law cause of action. Justice Souter is at pains to examine the issues in relation to what the two statutes have become at the present time, and what legislative policies would justify denying an individual federal damages "today." Thus, for him, making contemporary sense of congressional judgments was at the core; he worried that the majority's analysis would frustrate Congress's judgments by precluding $\S 1983$ actions in cases in which habeas would not be available-for example, because state proceedings had resulted only in a fine.

The majority opinion made no specific claim that the common law action for malicious prosecution was a congressional model for $\S 1983$; given Justice Scalia's distaste for legislative history, one would be surprised if an opinion of his rested on that kind of evidence. And the majority opinion's preference for the common law analysis may entail no necessary commitment to a static view. Section 1983, as it remarked, "creates a species of tort liability,"49 and that arms the opinion's reference to malicious prosecution. The discussion cites contemporary as well as nineteenth-century sources as to the meaning of both $\S 1983$ and that tort, ${ }^{50}$ appearing to address $\S 1983$ in the present day. What the common law action is for purposes of this federal action, however, appears to be dictated by external sources. The majority does not discuss it as if it were in any sense a federal tort. In relying on the "malicious prosecution" model, then, the majority hints at the subordination of the federal statute(s) to the common law.

Justice Thomas's characterization of the majority opinion, however, suggests the static view. He wrote separately to confess the Court's fault, as it were, for the situation that confronted it in this case: "it is we who have put $\S 1983$ and the habeas statute on what Justice Souter appropriately terms a 'collision course,'" by expanding both statutes "far beyond the limited scope either was originally intended to have." 51 The rhetoric suggests that this is a regrettable state of affairs, not the expectable consequence of judicial dealings with century-old statutes. "[T]hat the Court created the tension" is the factor that makes it "proper for the Court to

\footnotetext{
49114 S Ct 2364, 2370 (1994), quoting Memphis Community School Dist. v Stachura, 477 US 299, 305 (1986) and Carey v Piphus, 435 US 247, 257-58 (1978).

${ }^{50} 114 \mathrm{~S} \mathrm{Ct}$ at 2372.

${ }^{51}$ Id at 2374 (Thomas concurring).
} 
devise limitations ... provided that it does so in a principled fashion." 52 And Justice Thomas's one stated reason for finding the majority decision principled is that its approach is "consistent with the state of the common law at the time $\S 1983$ was enacted." 53 For him, at least, the echo of Gottshall is unmistakable.

\section{BFP V RESOLUTION TRUST CORP.}

The 5-4 split in BFP $v$ Resolution Trust Corp..$^{54}$ seems to illustrate the second of the problems in Gottshall, that of considering federal statutes in relation to the common law and judicial responsibilities for its formation. The question concerned the bankruptcy laws, in particular, the meaning to be attributed to 11 USC § 548(a)(2). That section permits the trustee in bankruptcy to avoid transfers for which "the debtor voluntarily or involuntarily . . . received less than a reasonably equivalent value in exchange for such transfer . . . and was insolvent on the date that such transfer was made . . . or became insolvent as a result of such transfer." BFP had purchased ocean-front real estate in California, obligating itself to sizable first and second mortgages on the property. It failed to make payments on the mortgages, and the first mortgage was foreclosed. At a properly conducted foreclosure sale, the property was sold for about $60 \%$ of its alleged fair market value-an amount that repaid the first mortgage, but left insufficient surplus to repay the second mortgage, much less contribute more generally to the bankrupt's estate. The question, then, was whether this "bargain" price constituted a "reasonably equivalent value in exchange for" the mortgaged premises.

Since its revision in 1984, the Bankruptcy Act has been explicit that it applies to involuntary as well as voluntary transfers, and that "foreclosure of the debtor's equity of redemption" is a "transfer." Shortly before the 1984 revisions, the Fifth Circuit, interpreting an analogous provision, had set aside a foreclosure sale that yielded $57 \%$ of estimated fair market value, stating that it thought $70 \%$ was the appropriate dividing line; ${ }^{56}$ in enacting $\S 548(a)$, Congress

\footnotetext{
${ }^{52} \mathrm{Id}$.

${ }^{53}$ Id at 2375.

${ }^{54} 114$ S Ct 1757.

${ }_{55} 11$ USC $\$ 101(54)$ (1988 ed, Supp IV).

${ }^{56}$ Durett v Washington Nat. Ins. Co., 621 F2d 201 (1980).
} 
rejected an alternative formulation that would explicitly have precluded the avoidance in bankruptcy proceedings of procedurally regular state foreclosure sales. Subsequently, the circuits divided on whether "reasonably equivalent value," in the mortgage context, referred to a price within reasonable range of what the property could have been expected to sell for on the open market (i.e., in the absence of a forced sale) or whether instead the phrase referred to a reasonable forced sale price, as would be received in a procedurally regular sale under state foreclosure law. Avoiding transfers at prices well under fair market value could provide additional resources for the bankruptcy debtor's other creditors to share and, perhaps, enlarge the debtor's estate for the fresh start that bankruptcy law promises. It would also render the title delivered at foreclosure sales somewhat less secure, arguably affronting state policies in this way.

Justice Scalia's opinion for the majority, joined by the Chief Justice and Justices O'Connor, Kennedy, and Thomas, discusses the federal statute at length, but seems to derive its principal impetus from this state policy concern, the effect of decision on the security of title resulting from foreclosure sales. As Justice Scalia sets out at some length, foreclosure sales are the result of a state common law process of development that sought to balance fairness to debtors (through participation in the proceeds of the sale) with protection to creditors and security of title. When federal bankruptcy law permitted the avoidance of fraudulent transfers, its focus was on fraud perpetrated by the debtor (also an inheritance from the common law). By contrast, the chance that a forced sale would generate an unfairly low price was dealt with by state law in varying ways - by state procedural requirements for such sales, including requirements to publish notice of such sales, and by state rules permitting a foreclosure sale to be set aside if it generated a price "so low as to 'shock the conscience or raise a presumption of fraud or unfairness." "'57 The constraints of time and the seller's requirement to sell will cause a forced sale to yield a lower price than a voluntary transaction. Since the precise character of those constraints in any given case will determine just how much lower that price will be, the referent of a "reasonably equivalent value" in the federal statute cannot be to a fair market price, but must be

${ }^{57} 114 \mathrm{~S}$ Ct at $1763-64$. 
to the price that would be received at a forced sale held in conformity with local law. ${ }^{58}$ Thus, for a sale held in conformity with local law, the price actually received is "reasonably equivalent" with that value, definitionally.

The unattractiveness of the alternative appears to have been a good part of the impulse for this conclusion. Justice Scalia could find no judicially administrable standard for a federal court to say, otherwise, what such a price could be. In a footnote, he dismissed a standard that would measure the reasonableness of the relation between forced sale price and fair market value under all the circumstances, as no different from "reasonably infinite value." $59 \mathrm{Be}-$ fore the 1984 revisions to the Bankruptcy Act, as already noted, the Fifth Circuit had set $70 \%$ of fair market value as a threshold of reasonable relationship; ${ }^{60}$ that, Justice Scalia thought, "represent[ed a] policy determination[] which the Bankruptcy Code gives us no apparent authority to make." ${ }^{61}$ Nor did he think the 1984 Act itself ratified the Fifth Circuit's work, despite its timing and the defeat of a measure that would have overruled it; that that Act might have modified his historical explanation, he barely considered: "absent clearer textual guidance . . . we will not presume such a radical departure." 62 The Seventh and Eleventh Circuits had more recently adopted a case-by-case "facts and circumstances"

\footnotetext{
${ }^{58}$ Justice Scalia also invoked formalist arguments in support of this position. "Reasonably equivalent value" should be given a different meaning from "fair market value," as the latter well-known phrase appears elsewhere in the Bankruptcy Code; different formulations should be given to different wordings. This is reinforced by the practical consideration that fair market value and forced sale price will almost inevitably differ. $114 \mathrm{~S} \mathrm{Ct}$ at 1761 . He says that he is interpreting "reasonably equivalent" as "roughly equivalent" or "approximately equivalent" rather than "tortur[ing]" the phrase to mean "as close to [fair market value] as can reasonably be expected," because the latter would express an empty proposition-no court could decide how close that was. Id at $1762 \mathrm{n} 4$.

This last move makes the argument an equivalent of that developed in text: choice of an arbitrary figure (like the Fifth Circuit's $70 \%$ ) would be beyond judicial authority; but a case-by-case factual analysis would lack governing rules. Justice Souter's dissent responded to the formalist argument by noting that "fair market value," a phrase that appears more than 150 times in federal tax legislation, appears only twice in the Bankruptcy Code (one of those times, in a tax-related section); "value," "unadorned and undefined ... appears in more than 30 sections of the Bankruptcy Code ... [and] is, with respect to many of them, read to mean 'fair market value.' "Id at $1768 \mathrm{n} 1$.

${ }^{59}$ Id at $1762 \mathrm{n} 4$.

${ }^{60}$ Durrett (cited in note 56).

${ }^{61} 114 \mathrm{~S} \mathrm{Ct}$ at 1762.

${ }^{62}$ Id at 1764.
} 
approach; ${ }^{63}$ as the footnote about "reasonably infinite value" suggests, that demonstrated the unsuitability of the matter for judicial determination.

As in Heck, Justice Souter, for the dissenting Justices, centered his opinion on federal rather than state law and policy, statutory rather than common law development. The language of $\S 548(\mathrm{a})(2)$ applies to all transfers, not just those occurring as a result of foreclosure sales; in every other context it naturally refers to fair market value, as the majority conceded. Justice Souter thought giving it a special meaning in the foreclosure context both indefensible on the language and contrary to federal bankruptcy policy. From the federal perspective, assuring adequate compensation at forced sales serves important purposes, both for the bankrupt estate itself and for other creditors. Such legislative history as exists suggests that Congress had been aware of this in 1984, when it added the references to involuntary transfers that picked up foreclosure sales as a matter of federal concern. It had rejected language that would explicitly have adopted the majority's view; the language it chose tended to echo the Fifth Circuit's prior holding. ${ }^{64}$ Not implausibly-if ironically-Justice Souter upbraided the majority for its attempt to escape the "plain effect" of these changes. Moreover, he argued, the Fifth Circuit rule had not proved embarrassing to security of title in operation, nor was there reason to think it would. Its chief effect would be to encourage bidders at forced sales to offer more than $70 \%$ of fair market value. That outcome would limit their bargain, to be sure, but do so in the service of important federal bankruptcy policies. It is hard to articulate a worthy state interest in having purchasers at foreclosure sales get unusual bargains, as against the federal policies favoring reasonable value to bankrupt estates. Nor was "case-by-case" determination, the alternative approach, an unusual judicial function as a general matter.

For a rather technical, even humdrum legal issue, the level of conflict between the two opinions is striking and the positions taken, even ironic. ${ }^{65}$ One line of strain, wholly familiar and articulated in both opinions, is whether state property or federal bank-

\footnotetext{
${ }^{63}$ In re Bundles, 856 F2d 815 (7th Cir 1988); In re Grissom, 955 F2d 1440 (11th Cir 1992).

${ }^{64} 114$ S Ct 1757, 1768 n 1; 1770 n 6; 1772 (1994) (Souter dissenting).

${ }^{65}$ Regarding the level of conflict, see David J. Garrow, "Justice Souter Emerges," New York Times (Sept 25, 1994), Sec 6, p 36.
} 
ruptcy policies are entitled to pride of place. Justice Scalia, widely experienced in federal government, ${ }^{66}$ generates his preference for the former from the long-established prior harmony of foreclosure and fraudulent conveyance law, and the importance of security of title. Justice Souter, from a state, common law tradition, ${ }^{67}$ reminds us that the Bankruptcy Act is a federal statute and the Supreme Court a federal court; state regulation must yield to the extent it actually conflicts with federal law, and Justice Souter argues strongly that a federal rule, once in place, will be so readily accommodated as hardly to inconvenience state interests.

In a number of respects, Justice Scalia's line of argument rests on the relatively weak stance toward federal judicial function we have already seen in Gottshall and Heck. For example, he devotes considerably more energy to his powerful exegesis of state common law development than to thoroughly working through the Bankruptcy Code, its changes and federal context. Perhaps most telling is his attitude toward the judicial fact-finding function that would be entailed in saying whether a price actually received at a foreclosure sale was fair in relation to the price that might have been expected on a voluntary sale market. Federal judges lack the means to make such determinations; Justice Scalia works hard to establish that $\S 548(\mathrm{a})(2)$ does not in terms command it. Yet he also takes reassurance from the possibility that state judges will perform the identical function, and may void forced sales if they conclude that the price was "so low as to 'shock the conscience of raise a presumption of fraud or unfairness." "68 What is it that makes this is a more acceptable judicial function at the state level? The only explanation Justice Scalia offers is that this set-aside occurs "under state foreclosure law, rather than fraudulent transfer law, "69 an observation that does not much illuminate the judicial function of comparing price and value.

\footnotetext{
${ }^{66}$ Justice Scalia had served on a White House telecommunications task force, as Chair of the Administrative Conference of the United States, as Assistant Attorney General in charge of the Office of Legal Counsel, and as a judge of a uniquely national court, the United States Court of Appeals for the District of Columbia Circuit, before coming to the Supreme Court.

${ }^{67}$ Virtually all of Justice Souter's prior government employment had been in New Hampshire, as a state attorney, Attorney General, and the Judge of its Supreme Court before a brief tour on the United States Court of Appeals for the First Circuit.

${ }^{68} 114 \mathrm{~S} \mathrm{Ct}$ at $1763-64$.

${ }^{69} \mathrm{Id}$ at 1763 (emphasis in original).
} 
Perhaps this opinion, like Gottshall and Heck, reflects a reluctance to consider federal judges to be common law judges, to be officials with acknowledged law-generating authority and responsibility. ${ }^{70}$ Common law judges - for example, state judges applying the test quoted above-often decide cases on the basis of "standards" as well as "rules." Common law emerges from the slow accretion of standard-based decisions over time. Administration of standards is common fare at trial if not at the appellate level. In his writings, Justice Scalia has argued against "standards" for federal judges; in his judgment, they can only be trusted with rules. ${ }^{71}$ Thus the approach of the Seventh and Eleventh Circuits, intellectually indistinguishable from the state court test Justice Scalia cites, creates a fact-bound standard, inappropriate for a federal judge. That is the burden of the dismissive footnote about "reasonably infinite value." The alternative, a $70 \%$ test like that of the Fifth Circuit, does create a "rule"; but the creation of "rules" is the constitutional business of Congress, not the courts. The circle is closed, and the failure to accomplish the sensible federal bankruptcy policy Congress almost certainly chose (to judge, that is, by the state of the law when it acted in 1984, by what it chose to say, and by what it chose not to say) is certainly no responsibility of the courts. Congress should be clearer.

\section{CIVIL RIGHTS ACT RETROACTIVITY}

The character of judicial-legislative dialogue, and judicial responsibility for implementing legislative judgment, acquire particular importance when the legislature and the courts have already established a pattern of disagreement in a given policy area. Continuing struggles inevitably acquire political coloration and invite political responses-from the creation of administrative agencies to take over responsibilities the courts prove unwilling to implement responsibly, to court-packing plans and other pressures on the ap-

\footnotetext{
${ }^{70}$ See Thompson $v$ Thompson, 484 US 174, 191-92 (1988) (Scalia dissenting).

${ }^{71}$ Antonin Scalia, The Rule of Law as a Law of Rules, 56 U Chi L Rev 1175 (1989). Compare Justice Scalia's acceptance of the obligation to use a standard, when inescapably imposed by statute, in Harris v Forklift Systems, Inc., 114 S Ct 367, 372 (1993) (Scalia concurring) (while the Court's interpretation of statutory language prohibiting sexual harrassment leaves juries "virtually unguided" in deciding whether employer conduct is "egregious enough to warrant an award of damages," "I know of no test more faithful to the inherently vague statutory language than the one the Court today adopts.").
} 
pointive processes. Interpretive techniques that stress plain language, refusing to improvise to secure congressional goals that might be demonstrated by the political history of legislation, extend those struggles if they require repeated expressions of congressional will until Congress "gets it right." That effect is even more pronounced if courts take legislative correction as only futureregarding, and are disinclined themselves to correct what are arguably their past errors. The burdens of securing change-and hence the opportunities for frustration and inefficiency-grow higher.

Rivers $v$ Roadway Express, Inc. ${ }^{72}$ and Landgraf $v$ USI Film Products ${ }^{73}$ were among the Term's more prominent cases. Mr. Rivers and a co-worker had been fired in 1986 in what they alleged to have been a racially discriminatory manner. Section 1981 of Title 42, part of the Civil Rights Act of 1866, conferred on all persons the right "to make and enforce contracts" free of racial discrimination; at the time, the United States Court of Appeals for the Sixth Circuit, where Rivers's job was, had interpreted $\S 1981$ to prohibit racial discrimination in the administration as well as the formation of contracts of employment, ${ }^{74}$ and the Supreme Court in dictum had appeared to approve the "well settled" conclusion in the courts of appeals "that $\S 1981$ affords a federal remedy against discrimination in private employment on the basis of race." ${ }^{" 75}$ In 1989 in Patterson $v$ McClean Credit Union, however, the Supreme Court had decided that $\S 1981$ 's conferral of the right was limited to contract formation, and did not apply to "conduct which occurs after the formation of a contract and which does not interfere with the right to enforce [it]." ${ }^{176}$ The suit Rivers had brought was thus dismissed; while appeal on a related matter was pending, the Civil Rights Act of 1991 amended $\S 1981$ to make explicit its application to "the making, performance, modification discrimination in terminating a contract of employment." 77 Rivers then argued for reinstatement of his suit.

\footnotetext{
72114 S Ct 1510.

${ }^{73}$ Id at 1483.

${ }^{74}$ Leonard $v$ City of Frankfort Elec. and Water Plant Bd., 752 F2d 189 (1985).

75 Jobnson v Railway Express Agency, Inc., 421 US 454, 459-60 (1975); see also Runyon v McCrary, 427 US 160 (1976).

76491 US 164, 171; see Aleinikoff, cited in n 29, an essay written as Patterson was pending, arguing strongly for an integrative reading of $\S 1981$.

${ }^{77}$ Section 101, Pub L No 102-166, 105 Stat 1071.
} 
Ms. Landsgraf had been subjected to repeated sexual harassment by a co-worker on her production line at USI Film Products and resigned in 1986 a few days after the firm appeared to respondalbeit mildly- to her complaints $;^{78}$ after a bench trial, a district court found the harassment not so severe as to constitute a constructive discharge, and denied the equitable relief that Title VII of the Civil Rights Act of 1964 then made available. While her appeal was pending, the Civil Rights Act of 1991 established a right to jury trial and to monetary damages in such Title VII actions, ${ }^{79}$ and she sought retrial before a jury. Both actions, then, called upon the Court to decide whether certain provisions of the Civil Rights Act of 1991 were to be retroactive in effect; in Rivers, the provision appears to have been enacted directly in response to the Court's unexpectedly narrow construction of the statute it amends.

The 1991 statute reflected the parlous quality of Congress's recent experience with the Supreme Court in civil rights matters, but it failed to deal directly with the retroactivity issue. Reversing earlier patterns, disagreement between the Court and Congress has become frequent in this area of the law, as the Supreme Court has announced interpretations of civil rights legislation frustrating both to civil rights plaintiffs and to a Congress that thought remedies available. A not insubstantial proportion of the Court's debates over proper approaches to legislative history and the role of "plain meaning" have arisen in that context. In one notable dissent, on the eve of the 1991 changes, Justice Stevens listed six recent opinions of the Court that had attracted congressional "correction" in civil rights legislation, upbraiding his colleagues for their seeming refusal to act in the spirit of congressional legislation, despite these consistent signals. ${ }^{80}$ (Earlier, when the Court was more often finding merit in civil rights actions, he had reflected the other side of that coin: in 1976 he joined the Court's opinion in Runyon $v$ McCrary, relying on a 1968 interpretation of $\S 1981$ that he thought "would have amazed the legislators who voted for it" in 1866, but

\footnotetext{
${ }^{78}$ After repeated complaints, her harasser was reprimanded and transferred within the firm; she quit four days later.

${ }^{79}$ Rev Stat $\S 1977$ A(a), 42 USC $\S 1981$ a(a), as added by $\S 102$ of Pub L No 102-166, 105 Stat 1071.

${ }^{80}$ West Virginia Univ. Hospitals v Casey, 499 US 83, 113-15 (1991) (Stevens dissenting).
} 
that had become well established and "surely accords with the prevailing sense of justice today"; ${ }^{81}$ his separate opinion in Patterson reiterated that theme. ${ }^{82}$ ) The 1991 act was passed after Congress had failed to override President Bush's veto of the Civil Rights Act of 1990 by the slimmest of margins. The 1990 Act had been explicit about retrospectivity, enacting that its provisions should govern litigation pending at its enactment; objection to that had been among President Bush's grounds for veto. The 1991 Act omitted that explicit language and provided generally that it should "take effect upon enactment," "except as otherwise specifically provided"; the only specific provisions were two sections that provided against retrospective application in litigation relating to particular Supreme Court judgments among those that the Act was overturning. Neither concerned the issues in Rivers or Landgraf.

The Chief Justice assigned both of the opinions to Justice Stevens, a striking gesture given Justice Stevens's views-both the specific views noted above, and his general preference for integrative approaches to interpretation, as is reflected in these pages. As Justices Scalia (writing), Kennedy, and Thomas complained in identical concurrences filed in the two cases, the result was a mixed signal. With the concurrers' enthusiastic agreement, the majority found against retrospective application of the two provisions. The general presumption against giving legislation retrospective effect, they reasoned, must be overcome by clearly manifested congressional intent; the muddle following the President's successful veto of the 1990 legislation could not supply that manifestation. But for the majority, whether such an intent had been manifested depended on an elaborate assessment of the actual course of debates, the political situation, and the likely realities of the legislative process; for the more formal Justices of the concurrence, this was an inappropriate inquiry. Moreover, while the majority refused to apply the new legislation to cases pending at its enactment-the formal question presented-it also catalogued and indicated its acceptance of the reversals, noting in part that the new legislation had not merely restored, but expanded the causes of action involved, and had added a number of provisions that were not expres-

\footnotetext{
${ }^{81}$ Runyon, 427 US at 189, 191 (Stevens concurring).

${ }^{82} 491$ US at 222. See text at note 99.
} 
sive of disagreement with Supreme Court precedent. ${ }^{83}$ The statute in Landgraf, enlarging the remedies available for violations of Title VII, was one of the latter. ${ }^{84}$

All this signaling of attentiveness to Congress's processes and stance toward the judiciary, and suggestion that future applications of the Act would be influenced by its spirit as well as its words, was galling to three who thought the governing principle clear. Absent a clear legislative statement in text otherwise, statutes apply only to relevant activity occurring after their effective date. It is unnecessary to say more. For them, it appears, Congress and the courts work in mutual isolation; and one may infer that (except to the extent it is expressed in unmistakably clear instructions) congressional frustration is not relevant to the courts' interpretive task. "We hear you" seems not to be an appropriate signal.

The limited statutory provisions against retroactivity persuaded Justice Blackmun, but none of his colleagues, that the other provisions of the act should apply to pending cases, "at least where application of the new provision would not disturb the parties' vested rights or settled expectations." ${ }^{85}$ USI Film Products could not have imagined in 1984-86 that it was entitled to engage in sexual harassment of Ms. Landgraf; in 1986, under the well-settled court of appeals interpretation of $\S 1981$ that seemed to have been approved by the Supreme Court, Roadway Express could not have imagined that it was entitled to engage in racial discrimination in administering Mr. Rivers's contract of employment. Justice Blackmun thought postponing the availability of new remedies, or prolonging the life of the congressionally repudiated decision in Patterson, could not be justified.

The majority's conclusion otherwise rested on a variety of considerations. In developing a general approach to the prospectivity question, it undertook a wide-ranging review of the Court's prior decisions in conventional common law manner and appeared to find the means- to the concurrence's considerable distaste- of preserving all. ${ }^{86}$ In reviewing at length the contentious political

${ }^{83} 114$ S Ct 1483, 1489 (1994).

${ }^{84}$ In providing the possibility of compensatory and punitive damage actions for Title VII, however, Congress eliminated one of the differences between Title VII and $\S 1981$ relief that had armed the majority argument in Patterson.

${ }^{85} 114 \mathrm{~S} \mathrm{Ct}$ at 1520 (Blackmun dissenting); see also $114 \mathrm{~S} \mathrm{Ct}$ at 1509 (1994) (Blackmun dissenting).

${ }^{86}$ Two decisions, Thorpe $v$ Housing Autbority of Durbam, 393 US 268 (1969) and Bradley $v$ Richmond School Board, 416 US 696 (1974), themselves both extending remedies in civil rights 
history of the measure (and its predecessor), it emphasized that the issue in this case was notorious and deliberately passed over. This review both signals Congress about its responsibilities when issues are on the table, and suggests a willingness to infer judgments that do not appear deliberately to have been withheld. In both cases, it appears to have been significant that the legislation undeniably created claims that would not have existed before its passage; it did not just revivify or expand available relief for existing claims. Thus, if the legislation had been given retrospective application here, it would have been difficult to deny its application to these new matters as well, unless by asserting a constitutional limitation-and that intellectual difficulty in itself supports a conclusion that Congress ordinarily should deal with such cases. All of this is rather supportive of, indeed premised upon, an interactive relationship in which legislature and courts learn from each other, and deal with each others' work product in a dialogic fashion.

At one point in Rivers, however, the majority takes a more formal stance that is worth examining. One element that makes the claim for retroactive application particularly strong, Justice Blackmun had argued, is that when trial began on Rivers's claim that he had been fired because of his race, the courts of appeals had held that $\S 1981$ forbade racial discrimination in the administration of contracts of employment; the Supreme Court had seemed to have approved those holdings. Patterson later held, however, that $§ 1981$ "does not apply to conduct which occurs after the formation of a contract and which does not interfere with the right to enforce established contract obligations. ${ }^{87}$ In the 1991 Act, Congress unmistakably provided that $\S$ 1981 does apply to such conduct, appearing thus to return $\S 1981$ to the meaning it had been given prior to the Patterson decision. To the majority, however, restoration is not simply a matter for the courts to infer judicially in response to the congressional action; it must be that Congress has itself enacted retrospectivity:

Patterson did not overrule any prior decision of this Court; rather, it held and therefore established that the prior decisions

settings, marked the Court's willingness to apply to pending cases "the law in effect at the time of decision," an outcome the concurrence thought "simply misread our precedents and invented an utterly new and erroneous rule." Like its attention to legislative history, preserving those decisions might be thought to suggest to the Court's partner in dialogue, Congress, that the Court would remain attentive to the appropriateness of retroactive application even when Congress had not been explicit ("clear") about the matter.

${ }^{87} 491$ US at 171. 
of the Courts of Appeals which read $\S 1981$ to cover discriminatory contract termination were incorrect. They were not wrong according to some abstract standard of interpretive validity, but by the rules that necessarily govern our hierarchical federal court system. Cf. Brown v Allen, 344 US 443, 540 (1953) (Jackson, J., concurring in result). It is this Court's responsibility to say what a statute means, and once the Court has spoken, it is the duty of other courts to respect that understanding of the governing rule of law. A judicial construction of a statute is an authoritative statement of what the statute meant before as well as after the decision of the case giving rise to that construction. ${ }^{88}$ Thus, Patterson provides the authoritative interpretation of the phrase "make and enforce contracts" in the Civil Rights Act of 1866 before the 1991 amendment went into effect on November 21,1991 . That interpretation provides the baseline for our conclusion that the 1991 amendment would be "retroactive" if applied to cases arising before that date.

Congress, of course, has the power to amend a statute that it believes we have misconstrued. It may even, within broad constitutional bounds, make such a change retroactive and thereby undo what it perceives to be the undesirable past consequences of a misinterpretation of its work product. No such change, however, has the force of law unless it is implemented through legislation. Even when Congress intends to supersede a rule of law embodied in one of our decisions with what it views as a better rule established in earlier decisions, its intent to reach conduct preceding the "corrective" amendment must clearly appear. We cannot say that such an intent clearly appears with respect to $\S 101$. For this reason, and because it creates liabilities that had no legal existence before the Act was passed, $\S 101$ does not apply to preenactment conduct. ${ }^{89}$

The formal element here is clearest in the last sentence of the Court's footnote: "[G]iven the structure of our judicial system, the

\footnotetext{
${ }^{88}$ When Congress enacts a new statute, it has the power to decide when the statute will become effective. The new statute may govern from the date of enactment, from a specified future date, or even from an expressly announced earlier date. But when this Court construes a statute, it is explaining its understanding of what the statute has meant continuously since the date when it became law. In statutory cases the Court has no authority to depart from the congressional command setting the effective date of a law that it has enacted. Thus, it is not accurate to say that the Court's decision in Patterson "changed" the law that previously prevailed in the Sixth Circuit when this case was filed. Rather, given the structure of our judicial system, the Patterson opinion finally decided what $\S 1981$ had always meant and explained why the Courts of Appeals had misinterpreted the will of the enacting Congress. [Court footnote; emphasis in original.]
}

${ }^{89} 114 \mathrm{~S} \mathrm{Ct}$ at $1519-20$ (emphasis in original). 
Patterson opinion finally decided what $\S 1981$ had always meant and explained why the Courts of Appeals had misinterpreted the will of the enacting Congress." ${ }^{.90}$ But this is a surprising characterization of "our judicial system" from a common law point of view. Justice Stevens would not normally contend that the only proper meaning for $\S 1981$ is the meaning it had upon enactment in 1866: He had in fact taken a quite different view in joining the Court's opinion in Runyon ${ }^{91}$ and in Patterson ${ }^{92}$ itself; the other cases of the 1993 Term saw him, quite characteristically, regularly promoting meanings that had emerged through judicial exposition, and judiciallegislative interaction, over time. This is the characteristic common law process, which incrementally takes the law to places it previously has not been and applies those results to facts that occurred (of necessity) before the court acted. The law of product liability and the law of antitrust are both relatively stable; but both have shifted enormously since the late nineteenth century and neither still depends for its legitimacy on ideas of what it has "always meant." That courts are constrained to the text of statutes, as they are, does not entail treating their words as an immanent, brooding omnipresence. The existing body of statutes, no less than the existing doctrines and trends of the common law, inform contemporary judicial judgment; to insist that the statutory part is static in its content, that legislation must be taken to mean what it "always meant," is to rob judicially administered law of its most democratic element by subtracting the impulse to build on the policies set in motion by legislatures and restricting the building to policies generated by courts. ${ }^{93}$

An alternative way of understanding the situation would be to frame the question, not in terms of the retrospectivity of the 1991 Act, but as whether the Court would have been justified in overruling Patterson. We know from other work of the Term that the Court has not hesitated to overrule its prior interpretations of statutes even when Congress has not acted. Overruling has, perforce, a retrospective effect, since the Court acts in the case before it, and that case arose under-or, as in Rivers, at least passed through

\footnotetext{
${ }^{90} \mathrm{Id}$; emphasis in original.

${ }^{91}$ See text at $\mathrm{n} 81$.

92 See note 99.

${ }^{93}$ See Pound (cited in n 5), and Stone (cited in n 8).
} 
the shadow of - the interpretation that is to be discarded. If, with the rest of law, statutes evolve, ought a court to take prompt legislative repudiation of its conclusions as a sign that it was in error? This is not a rhetorical question, and in some respects the majority opinion wrestles with its difficulties: A legislative response, even if in some respects generated by a corrective impulse, may head off in such fresh or varied directions as to sap its action of that implication. Or, the judicial action being responded to may have been entirely in line with its precedents, so that it served merely to emphasize the need to attend to a long-standing problem of policy.

But Patterson was itself a sharp change of direction from the body of judicial precedent that had previously developed under the aegis of $\S 1981$. While it is certainly true, as the Court remarks, that the hierarchical nature of the judiciary established, in a formal sense, "that the prior decisions of the Court of Appeals . . . were incorrect, ${ }^{, 94}$ those decisions had previously reflected, and in turn served to generate, a climate of understanding respecting legal obligation in contemporary society that, until the Court acted, both had the force of law and deprived an agreeing legislature of any need to act. Supreme Court judgments are final, but the Court is not and need not pretend to be infallible. Observing the speed with which the law has been returned by the legislature to its prior state (and more), a court exhibiting the sensitivity Justice Stevens has generally shown to the dialogic qualities of law could easily conclude that it had been wrong in its earlier reading, and overrule it. That would not give the statute retrospective effect; what has been overruled is the earlier decision, and any fresh legislative judgments are naturally limited to future effect. It would avoid the embarrassment of having to apply repudiated social policy to facts that arose under other expectations, as in Rivers. ${ }^{95}$

To put the proposition this way again illuminates the sometimes strangeness of the boundary between the (common law) courts and the legislature. In Patterson itself, the reader may recall, the Su-

\footnotetext{
${ }^{94}$ Supra; emphasis in original.

${ }^{95}$ The argument is less strong for the period 1989-1991, between Patterson and the 1991 Act. During virtually all that time, however, actors were on notice that retrospective application of an explicit congressional overruling was likely; in the usual terms in which common law courts consider the fairness of retrospective application of new doctrine, no more is required.
} 
preme Court had invited argument whether Runyon should be overruled. It unanimously decided against that step, then dividing 5-4 over the interpretation of $\S 1981$ that defeated existing expectations, and that the 1991 Act repudiated. The controlling opinion was written by Justice Kennedy; it carefully avoided saying whether Runyon was decided incorrectly or not, invoking instead considerations of stare decisis "that have special force in the area of statutory interpretation." ${ }^{.96}$ But it was emphatic that these considerations attached to the opinion, not the statute the opinion had read. "Congress may legislate . . . only through the passage of a bill which is approved by both Houses and signed by the President. Congressional inaction cannot amend a duly enacted statute. ${ }^{197}$ It would be a reason to overrule even statutory precedent, the majority agreed, if "the intervening development of the law, through either the growth of judicial doctrine or further action taken by Congress[, has] removed or weaked the conceptual underpinnings from the prior decision or . . . rendered the decision irreconcilable with competing legal doctrines or policies," if that precedent was "a positive detriment to coherence and consistency in the law," or if, "after being " "tested by experience, [it] has been found to be inconsistent with the sense of justice or the social welfare." "98 These descriptions of the proper basis for overruling even statutory precedent seem to fit the Rivers situation well; in Patterson, Justice Stevens's separate opinion had criticized the majority in just such terms:

The Court's repeated emphasis on the literal language of $\S 1981$ might be appropriate if it were building a new foundation, but it is not a satisfactory method of adding to the existing structure. In the name of logic and coherence, the Court today adds a course of bricks dramatically askew from "the secure foundation of the courses laid by others," replacing a sense of rational direction and purpose in the law with an aimless confinement to a narrow construction of what it means to "make" a contract. ${ }^{99}$

\footnotetext{
${ }^{96} 491$ US at 172.

${ }^{97}$ At $175 \mathrm{n} 1$.

${ }^{98}$ At 173-74, omitting citations.

99 At 222. The concluding passage quotes Justice Stevens's opinion in Runyon, in turn quoting Benjamin Cardozo's The Nature of the Judicial Process 149(1921), explaining his reasons for joining an opinion interpreting $\S 1981$ in a manner he thought its drafters could not have imagined.
} 
Petititioners seem not to have argued Rivers in this way; and one notes that the Chief Justice and Justice O'Connor subscribed to both Justice Kennedy's opinion in Patterson and Justice Stevens's opinion here. Still, to say that a prior Court interpretation is revealed to have been wrong is not the same as giving retroactive effect to a statute whose prompt enactment may contribute to that judgment; and eliding that argument tends to hide from view the important judicial responsibilities, in partnership with Congress, that Justice Kennedy's Patterson considerations acknowledge.

\section{E. HOLDER V HALL}

Holder $v$ Hall, ${ }^{100}$ a Voting Rights Act case decided on the last day of Term, captures the static quality of Justices Thomas's and Scalia's approach to statutes, their disinterest in congressionaljudicial dialogue, and Justice Stevens's position at the opposite pole. A Georgia county conferred on its single elected commissioner all the county's elective authority, executive and legislative; at issue was whether this arrangement was a "standard, practice or procedure ... which results in an abridgement or denial of the right of any citizen of the United States to vote on account of race or color," in violation of Section 2 of the Voting Rights Act of $1965{ }^{101}$ Whites held a slim population majority in the county, and the contention was that choosing the single-commissioner form of government rather than a multimember "legislature" discriminated against blacks by "diluting" their vote. None but whites had been elected to (or run for) this county office, although blacks had stood for and been elected to the multimember county school board.

Vote dilution is not explicitly a violation of Section 2 or the similarly worded Section 5; both in terms appear to deal only with obstacles to physical registration and voting. Like the Civil Rights Act of $1964,{ }^{102}$ the Voting Rights Act was adopted just as southern resistance to civil rights legislation had been overcome; as had been the case with that Act, its supporters in Congress made no grand

\footnotetext{
${ }^{100} 114$ S Ct 2581 (1994).

10142 USC § 1973.

10242 USC $\$ 2000 \mathrm{e}-2(\mathrm{a})$ and (d); cf United Steelworkers of America $v$ Weber, 443 US 193 (1979), and the continuing debate over the meaning of Title VII. The similarity is explicitly recognized in Justice Ginsburg's separate dissent, which stresses the challenge posed to the courts when congressional politics result in compromise outcomes. $114 \mathrm{~S} \mathrm{Ct} 2581,2624$ (1994) (Ginsburg dissenting).
} 
claims for its reach-indeed, tended to present it as its words suggested, as concerned with access to the ballot, and not proportionality of representation. A court acting in the late 60's or early 70's would have found it easier, as a technical matter, to give the Act correspondingly narrow meaning. The Supreme Court's 1969 decision in Allen $v$ State Board of Elections, ${ }^{103}$ however, broadly interpreted the language of Section 5 to reach "all action necessary to make a vote effective," 104 including the matter of vote dilution; in 1986, the Court specifically applied Section 2 to the problem of vote dilution in its decision in Thornburg $v$ Gingles. ${ }^{105}$

Six opinions were written in Holder; no more than two Justices agreed fully with any of three plurality opinions finding that the Georgia practice did not violate Section 2. Justice Thomas's opinion was one of those three; ${ }^{106}$ Justice Stevens's, one of three dissents. ${ }^{107}$ Most of the opinions accepted the existing case development as a starting point, and then asked whether the "dilution" concept could reasonably be applied on the facts of the case presented to the Court. As the number of opinions suggests, that task proved both difficult and controversial.

Justice Thomas took a different approach, returning to the interpretive question as an initial matter. Whether analyzing the text alone (as he emphatically prefers) or viewing the legislative history as a whole, he found it limited to obstacles to physical registration and voting - that the statute did not reach behaviors that might tend to imbalance voter influence on outcomes along racial lines, as long as the vote itself was assured. That then presented him with a question he characterized in strictly judicial terms, a question of stare decisis, whether the Court should continue to adhere to its prior decisions; and that question he thought answered by the unmanageability and inappropriately political character for judicial action of the task the Court had set for itself. The opinion was a major undertaking, substantially longer than the other five opinions

\footnotetext{
103393 US 544.

104 At 565-66.

${ }^{105} 478$ US 30 (1986).

${ }^{106}$ Justices Kennedy and O'Connor also wrote.

${ }^{107}$ Other dissents were filed by Justices Blackmun and Ginsburg. Justice Blackmun's dissent on the merits was joined by Justices Stevens, Ginsburg, and Souter; Justice Stevens's response to Justice Thomas was also joined by all his dissenting colleagues.
} 
combined, and this brief account can hardly capture it; its fervor may be suggested by the following:

In my view, our current practice should not continue. Not for another Term, not until the next case, not for another day. The disastrous implications of the policies we have adopted under the Act are too grave; the dissembling in our approach to the Act too damaging to the credibility of the federal judiciary. ${ }^{108}$

What is striking and illustrative about the argument for current purposes is its quality of stasis. The statute is what it was on its adoption in 1965. Postenactment history is consulted only in acknowledging that stare decisis is often sound policy in matters of statutory construction, and in examining whether the past interpretations of the Court have proved refractory or unworkable (a subject about which, I wish to be clear, it appears reasonable arguments can be made).

At the center of Justice Stevens's responsive dissent are a series of intervening congressional events to which Justice Thomas does not refer:

In 1970, one year after Allen, and with that case and its implications before it, Congress reenacted Section 5 without change. In 1975 , it did so again.

In 1982, now after over a decade of broad interpretation of the statutory references to voting "standard, practice or procedure," Congress further amended Section 2 to extend its application to circumstances the Court had recently found outside the statute as initially written; ${ }^{109}$ henceforth, Section 2 was to reach invidious results as well as invidious purposes. ${ }^{110}$

That is, Congress's consistent pattern, in dealing with a statute of high political moment and visibility, had been to leave the Court's expansive interpretations undisturbed, and to override the limitations that the Court did find in it. These facts took the case well beyond simple congressional silence in the face of judicial interpretation; they involved reenactment, high controversy, and indeed statutory change hard to understand other than as implicit approval of judicial constructions to date.

\footnotetext{
${ }^{108} 114 \mathrm{~S} \mathrm{Ct}$ at 2618.

${ }^{109}$ Mobile v Bolden, 446 US 55 (1980).

${ }^{110} 114 \mathrm{~S} \mathrm{Ct}$ at 2626-27.
} 
When a statute has been authoritatively, repeatedly, and consistently construed for more than a quarter century, and when Congress has reenacted and extended the statute several times with full awareness of that construction, judges have an especially clear obligation to obey settled law. ${ }^{111}$

For Justice Stevens and his colleagues, the statute and the Court's interactions with Congress are organic. For Justices Thomas and Scalia, Congress's work concluded with enactment; subsequent events are relevant (if at all) only to establish the workability or not of the Court's approach to the original issue of meaning-an issue that remains open to revision in accordance with the original understanding, however expectations and general law may have changed in the interim.

\section{F. THREE EASIER PIECES}

In three civil cases decided fairly early in the Term, perhaps less difficult and in any event somewhat less adventurous in their claims on the Court, the seams between statute and case law were less evident.

In American Dredging Co. $v$ Miller, ${ }^{112}$ the Court was faced with Louisiana's statutory decision to make the doctrine of forum non conveniens unavailable in Jones Act and maritime law cases brought in its courts. ${ }^{113}$ The frequent involvement of foreign ships and sailors gives issues of the appropriateness of American venues particular significance in admiralty. As it happened, plaintiff and defendant in this case were both domestic. Justice Scalia emphasized that tact in his opinion for a majority of six, upholding Louisiana's choice; he stressed, too, that state courts would be unable to exercise in rem jurisdiction that could result in the possibly embarrassing impoundment of a foreign vessel. Thus, Louisiana may find itself more limited in cases arising out of international commerce than the decision at first suggests.

Two strands characterize Justice Scalia's majority opinion. The

\footnotetext{
${ }^{111}$ Id at 2629.

112114 S Ct 981 (1994). American Dredging was not produced by the Lexis search described above, note 43 , but is mentioned at the suggestion of my colleague John Manning, who argued the case for the Solicitor General as amicus curiae.

${ }^{113}$ Strikingly, Louisiana made this judgment only for admiralty cases; the majority asserted that the propriety of this discrimination was "a question not remotely before us." $114 \mathrm{~S} \mathrm{Ct}$ at $988 \mathrm{n} 3$.
} 
first, less interesting for our purposes, applies a test for preemption in admiralty cases first articulated in 1917 and finds that Louisiana's choice is not preempted. ${ }^{114}$ The second examines the relationship among the Jones Act (the maritime remedy for seamen under which this particular action was brought) and FELA, the more general statute also involved in Gottshall. The Jones Act incorporates FELA by reference, and FELA also requires state courts to apply uniform federal law; but an early decision under FELA nonetheless permitted state courts to apply their own principles of forum non conveniens. ${ }^{115}$ "We think it evident that the rule . . . announced for the FELA applies as well to the Jones Act, which in turn supports the view that maritime commerce does not require a uniform rule of forum non conveniens." 116 The statutory judgment which the Court first found in FELA is carried through by implication at least to Jones Act litigation, without any need to see that judgment expressed in the Jones Act text.

Justice Kennedy (with Justice Thomas) dissented from this "harmonization of general admiralty law with congressional enactments," 117 seeming to give dominant force to the Court's common law responsibilities in a setting in which they are particularly strong. ${ }^{118}$ The admiralty jurisdiction, he thought, imposed a

\footnotetext{
${ }^{114}$ Southern Pacific Co. v Jensen, 244 US 205, 216 (1917). Justice Stevens, in a lone concurrence, strongly objected to unnecessarily giving life to Jensen, a 5-4 decision he characterized as of a piece with Locbner $v$ New York, 198 US 45 (1905), in its attitude toward state legislative authority trenching on admiralty. The specific holding in Jensen was that New York could not apply workers' compensation remedies to a longshoreman injured in the admiralty jurisdiction; thus, the result was among those suggesting a certain judicial hostility to legislative innovations seeking to overcome the then cruelty of the common law. See text at note 3. It was in dissent here that Holmes proclaimed the necessarily "interstitial[]" quality of judicial policy-making, and that "[ $t$ ]he common law is not a brooding omnipresence in the sky but the articulate voice of some sovereign or quasi-sovereign that can be identified." 244 US at 221, 222, quoted in $114 \mathrm{~S} \mathrm{Ct}$ at 991, n 1 (Stevens dissenting). Is it too much to find, in this particular cleavage between Justice Scalia and Justice Stevens, some echo of a similar disinclination on Justice Scalia's part to use statutory instruction to the fullest? Note that Justice Scalia prefaces his discussion of the matter next discussed in the text, on which he and Justice Stevens agree, by characterizing it as a secondary point and observing that "[w]hile there is an established and continuing tradition of federal common lawmaking in admiralty, that law is to be developed, insofar as possible, to harmonize with the enactments of Congress in the field." (Emphasis added.) Id at 989. That is, separation is insisted upon and judicial primacy asserted. Admiralty is one of the few contexts in which Justice Scalia admits a common law function for federal courts. Compare note 70.

${ }^{115}$ Missouri ex rel. Southern R. Co. $v$ Mayfield, 340 US 1 (1950).

$116114 \mathrm{~S} \mathrm{Ct}$ at 990.

${ }^{117}$ Id.

${ }^{118}$ Id at 995.
} 
strong, implicitly constitutional obligation of uniformity. FELA is a domestic statute; litigation about railroad activity "interposes no obstacle to our foreign relations." 119 The Jones Act makes no explicit judgment about forum non conveniens, and the Court's opinion in any event reaches the whole of admiralty jurisdiction, not just Jones Act cases. Absent assurance that foreigners could be protected from inconvenient fora, which he could not find in the majority opinion, he would not build an exception from uniformity on the basis of FELA. The worlds of statute and common law are more widely separated here-but also with an assignable reason on the merits that has its own intellectual force. It is hard to take the implication here that the exercise would be generally inappropriate.

Formally at issue in Liteky $v$ United States ${ }^{120}$ was the meaning to be attached to 28 USC $\S 455(a)$, which since its amendment in 1974 has required a federal judge to recuse "himself in any proceeding in which his impartiality might reasonably be questioned." Disqualification was sought on the basis of a judge's conduct of politically charged trials, and the Court was unanimous that it was not required on the facts before it. Justice Scalia wrote for the Chief Justice and Justices O'Connor, Thomas, and Ginsburg; Justice Kennedy wrote for the remainder, concurring in the result. The majority's analysis was somewhat more formal than the concurrence; the latter thought Justice Scalia emphasized too greatly doctrinal structure (whether the disqualifying impulse must come from an "extrajudicial source") and drew unwarranted limitations to the broad principle of $\S 455(\mathrm{a})$ from the series of specific prohibitions that is set out in $\S 455(\mathrm{~b})$. Most striking for our purposes, however, is that both opinions were content to regard $\S 455$ as establishing the foundation upon which judicial doctrine about disqualification would be built. The statute here was imagined as a starting point, rather than an isolated and unchanging diktat. No complaint is uttered about Congress's failure of clarity in specifying so subjective an inquiry, nor is Congress pointed out as the only proper source of any appropriate clarification. The Court builds on cases that preceded the 1974 amendment and are assumed to have in-

\footnotetext{
119 Id.

${ }^{120} 114$ S Ct 1147 (1994).
} 
formed it, and on cases that followed that amendment and contribute to understanding its meaning.

Possibly the statute's concern with judicial administration underlies the ease with which all members of the Court seem able to treat it as establishing a somewhat malleable framework, rather than an unchanging specification. Disqualification may seem like it should be judicial business in the first instance, so that treating the statute as confirmatory and instructive rather than as an external command has an intuitive if unexpressed appeal. To be confirmed oneself in substantial discretion of administration is perhaps less alarming than to see that discretion awarded to another body. The minority-Justices who, save Justice Kennedy, were characteristically more wedded to integrative perspectives throughout the Term-are prepared to see Congress's instruction in less confining a way than the majority; but even the majority approaches the task with a willingness to examine context and shoulder the premises and responsibilities of continuity that were missing from much of the Term's work.

Somewhat to the same effect was Fogerty $v$ Fantasy, Inc. ${ }^{121}$ where the question was whether courts should employ differing standards in assessing the requests of prevailing plaintiffs and prevailing defendants for the award of attorneys fees in copyright infringement actions under 17 USC $\S 505$. Section 505 provides that "the court may ... award a reasonable attorney's fee to the prevailing party as part of the costs," drawing no textual distinction between successful prosecutors and successful defenders of infringement actions. In earlier decisions construing essentially identical language in the Civil Rights laws, however, the Court had differentiated between plaintiffs and defendants, finding that successful plaintiffs should "ordinarily" recover attorneys' fees unless "special circumstances would render such an award unjust," but that successful defendants were not entitled to a similar presumption. ${ }^{122}$ Those earlier decisions identified as a purpose of the Civil Rights laws the encouragement of often "impecunious" plaintiffs' actions, to vindicate congressional policies of the highest priority; and they

\footnotetext{
$121114 \mathrm{~S}$ Ct 1023.

${ }^{122}$ See 42 USC $\S 2000$ e-5(k) ("in its discretion may allow the prevailing party . . . a reasonable attorney's fee"); Newman v Piggie Park Enterprises, Inc., 390 US 400, 402 (1968) (successful plaintiff's presumptive recovery); Christianburg Garment Co. v EEOC, 434 US 412 (1978) (successful defendants not entitled to presumptive recovery).
} 
relied in part on legislative history supporting that understanding. The Justices were unanimous that these earlier constructions were not controlling, but they were not unanimous in their reasoning.

The Chief Justice, writing for eight members of the Court, saw a policy distinction between the two statutes that produced no embarrassment: copyright plaintiffs were no more likely to be impecunious than copyright defendants, nor did they have a special "private attorney general" role in enforcing a particularly important congressional policy. And the majority considered with some care whether the legislative history of $\S 505$, or the prior history of the attorney's fee issue in copyright litigation, would itself support a dual standard-concluding that neither would. The premise of such inquiries into context must be that congressional action is appropriately to be understood in the framework of expectations about law that exist at the time. The questions would not have been necessary if the earlier civil rights statute, and its interpretation, had no intellectual bearing for the copyright law. Only Justice Thomas took that position, in a solitary concurrence; he stressed that straightforward attention to the text was the better analysis, would have preferred to limit if not abandon the earlier readings as error, and regretted the resulting inconsistency in construing the virtually identical language of the Copyright and Civil Rights Acts. For him, but in this case only for him, text alone, and not the context of its adoption, had bearing.

\section{Criminal Cases}

\section{A. SHANNON $v$ UNITED STATES}

On the same day as the Court decided Gottshall, Justice Thomas, and Justice Stevens, each took a similar approach in Shannon $v$ United States, ${ }^{123}$ a criminal case in which the defendant relied alternatively on an asserted congressional-judicial interaction, and on the Supreme Court's supervisory power over federal criminal power-its common law function in that respect. At issue was whether a trial court had erred in refusing a defendant's request for a jury instruction explaining the consequences of a verdict of

${ }^{123} 114$ S Ct 2419 (1994). 
Not Guilty by Reason of Insanity under the relatively new Insanity Defense Reform Act of 1984.

Prior to 1984 , no statute had governed the use or consequences of the insanity defense in federal criminal trials outside the District of Columbia. Congress had enacted such a statute for the District in 1955. In 1957, the D.C. Circuit had decided en banc that, given juries' probable unfamiliarity with the insanity defense, defendants were entitled to have juries informed about the consequences of a verdict of not guilty by reason of insanity, despite the usual unwillingness of courts to invite juries to consider the consequences of their action:

We think the jury has a right to know the meaning of this possible verdict as accurately as it knows by common knowledge the meaning of the other two possible verdicts. ${ }^{124}$

This opinion was uncontroversial and had been followed for almost three decades when, in the wake of the assassination attempt on President Reagan, Congress enacted the general federal statute. The 1984 statute was generally modeled on the District Act, although many of its specific judgments were somewhat harsher toward the defense. ${ }^{125}$ The procedure the D.C. Circuit put in place was "endorse[d]" by the Senate Committee in its report, apparently the only mention of the matter in the legislative history. ${ }^{126}$

Justice Thomas, writing for all but Justices Stevens and Blackmun, concluded that the defendant had no right to the instruction that he sought. The text of the new Act did not address this problem. Examining its several changes, he found that it varied sufficiently from its D.C. predecessor to make "inapplicable" the canon that when a statute with a settled construction is borrowed, its settled interpretation is presumed adopted as well. In a footnote, he added a comment that very sharply distinguishes between the

\footnotetext{
${ }^{124}$ Lyles v United States, 254 F2d 725, 728 (1957); Judge, later Chief Justice, Warren Burger was one of the authors of this opinion.

${ }^{125}$ As detailed in the majority opinion, the insanity test is more restrictively formulated. Also, a federal defendant must affirmatively establish the defense by clear and convincing evidence, not a mere preponderance; is subject to a civil hearing within $\mathbf{4 0}$ days, not 50 ; in a serious matter must show entitlement to release by clear and convincing evidence, not a preponderance; and, if then committed, will be released only when he no longer presents a substantial risk of harm to others or their property, rather than when he has ceased to be "dangerous to himself or others."

${ }^{126} \mathrm{~S}$ Rep No 98-225, 240 (1983), quoted in $114 \mathrm{~S}$ Ct at 2426.
} 
worlds of statute and case law: since the D.C. Circuit's action had been taken under its supervisory authority over federal courts in the District rather than as an act of statutory construction as such, a "canon of statutory construction" would be inapplicable; "there was no 'known and settled construction' of the statute that Congress could have adopted by virtue of borrowing language from the D.C. statutory scheme." 127 But the District of Columbia's criminal bar is unlikely to have distinguished between "statutory construction" and how it knew the D.C. statute had been applied without controversy or difficulty for three decades. Nor would the Court adopt the D.C. approach judicially, fearing that "the rule against informing jurors of the consequences of their verdicts would soon be swallowed by the exceptions" if the Court adopted Shannon's argument as an exercise of its supervisory power over the federal courts. ${ }^{128}$ And, again, the majority found force in an argument that tends to isolate the world of Congress from the world of the court: "Congress's recent action in this area counsels hesitation in invoking our supervisory powers." 129 Congress is thus credited with having chosen by not acting, when its only relevant experiencewhich the Court does not permit itself to know-is that judicial exercise of supervisory powers had well solved the issue.

A similarly sharp division between the two worlds is reflected in the majority's treatment of the Senate Committee Report. While acknowledging that Justices hold "differing views regarding the role that legislative history should play in statutory interpretation," Justice Thomas was "not aware of any case . . in which we have given authoritative weight to a single passage of legislative history that is in no way anchored in the text of the statute." ${ }^{130}$ In the abstract, one easily agrees that a "snippet of legislative history" lacking any "statutory reference point" ought to be disregarded. But here the point is tenable only if the "snippet" is itself read in isolation-if one's premise is that legislators act in the abstract, without any knowledge of or stance toward the existing body of law. Once we permit ourselves as well as the Senate to know about

\footnotetext{
${ }^{127} 114 \mathrm{~S} \mathrm{Ct}$ at $2426 \mathrm{n} 8$ (emphasis in original).

${ }^{128}$ Id at 2428.

129 Id.

${ }^{130}$ Id at 2426. Passages like these appear to be building a wall of defense against the future return of attention to legislative history.
} 
the 1955 statute and its well-established and uncontroversial interpretation, the "snippet" becomes not an isolated scribble but "as much as you could expect." There wasn't a problem requiring legislative resolution in the context against which the Senate was acting. To require advance legislative identification and explicit resolution of all issues, including those that are not issues, is to ask what cannot be done. Failing to anticipate what a court might insist upon, Congress had no reason to say more than it did. Justice Thomas's position holds as a matter of logic; it fails as a description of events that acknowledges the continuing interaction of all the bodies responsible for law's development, and the expectations that interaction engenders. ${ }^{131}$

For Justices Stevens and Blackmun, "a rule that has minimized the risk of injustice for almost 40 years should not be abandoned without good reason." ${ }^{132}$ Fears of possible unfairness to defendants are answered by the need for defendants to request the charge; fears that the general rule against informing jurors of the consequences of their verdicts would be swallowed up by exceptions are answered by the connection here to a particular statute, and by the experience of almost 40 years in the D.C. courts that no such expansion had occurred. The Court need not simply "presume" a prior construction had been adopted by Congress, when it is evident that construction was actually known to the legislature and was uncontroversial-indeed, they suggest, the D.C. approach was the developing trend in the states generally.

One opinion sees an abstract question, and works hard to preserve it in that frame. Indicators that might place it into a developmental context or frame the issues in dialogic terms are rejected. For Justice Thomas in this case, Congress doesn't act in a contextits obligations are to see to it each time that all its instructions are clear-and neither should the Court. The other opinion is grounded in a premise that law is developmental, that what occurs at any moment is informed by what has gone before, by the perva-

\footnotetext{
${ }^{131}$ Compare the discussion of City of Chicago v EDF, discussed in text at 499. One could add, perhaps, that in preferring what he found to be the usual treatment of this issue in state courts over that developed in the District of Columbia, a distinctly federal jurisdiction, Justice Thomas again reflects a preference for judicial development of law dependent on state rather than federal sources, even when federal questions are unmistakably involved. See text at $\mathrm{p} 436$.

$132114 \mathrm{~S} \mathrm{Ct}$ at $2428-29$.
} 
sive set of expectations against which, necessarily-their time and insight limited-humans act. And here, of course, the Court was also presented with the alternative of acting in common law mode, in the exercise of supervisory jurisdiction (as in this context that is called). For one writer, that possibility was to be evaluated by possible logical extensions of the desired holding; ${ }^{133}$ for the other, by practical experience and the apparent trend in other jurisdictions.

\section{B. STAPLES V UNITED STATES}

Justices Thomas and Stevens again took opposed positions in Staples $v$ United States, ${ }^{134}$ but in this opinion Justice Thomas used contextual materials more freely, and in the service of finding against criminal liability; Justice Stevens was perhaps the more attentive to the statute in itself. Staples possessed a gun, originally a semiautomatic weapon, that had been modified so that it would fire repeatedly on one pull of its trigger. That modification made it a machine gun under the National Firearms Act; ${ }^{135}$ the Act defines as an offense punishable by up to 10 years in prison the possession of a machine gun that has not been federally registered. ${ }^{136}$ The government prosecuted Staples for failing to register the gun. The question dividing the Court was the scienter required to support his conviction. Should the jury have been instructed that it must find that Staples himself knew that the gun had been modified to make it a fully automatic weapon? Or was it enough to have been told, as in fact they were, that they must find that the gun Staples knew he had, and had not registered, had been so modified? Justice Thomas wrote for five Justices that to support

\footnotetext{
${ }^{133}$ Compare Priestly v Fowler, 3 Mees. \& Wels. 1, 150 Eng Rep 1030 (Exch Pleas 1837); Winterbottom $v$ Wrigbt, 10 Mees. \& Wels. 109 (Exch Pleas 1842), opinions by Lord Abinger long taken as caricatures of fear-ridden reasoning. Over the course of a century and a half, Lord Abinger's fears have been born out; and so, perhaps, would Justice Thomas's be. The concern is not irrelevant; yet time frame and pace are central to its legitimacy. If that change were to occur slowly, it would presumably be because of the accretion of factual circumstances demonstrating that that would be the just outcome, and in the absence of legislative reaction to the direction taken by the courts. Once again, then, the fundamental imperative here is that of stasis. Such opinions trust the future no more than they consult the past.

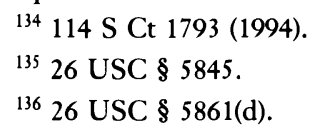


conviction Staples had to have known that the gun was an automatic, and therefore his conviction must be reversed; Justices Ginsburg and O'Connor concurred in that result; Justices Stevens and Blackmun dissented, believing that the semiautomatic character of the gun together with its modification in fact were enough to establish criminal liability.

Justice Thomas's opinion is integrative in significant respects, drawing on a wide range of other opinions and statutes in reasoning to its conclusion favoring a relatively demanding scienter standard. It derives its principal thrust from propositions that might be disputed, but that plainly figure as policy threads running through the law - that the general legality of gun ownership in our society and the severity of the sentence Staples might receive argue for regarding the offense as a regulation of conduct malum in se rather than as an offense to public welfare. (Public welfare offenses, all agreed, do not require proving scienter in the manner the Staples majority required.) The text of the National Firearms Act does not answer the question of what state of mind is required for violation of its provisions; the Act is to be construed, Justice Thomas said, in light of the "background rules of the common law," 137 but in this case witbout the dating that had characterized his opinions in Gottsball ${ }^{138}$ and Heck. ${ }^{139}$ In a criminal case, interpretations varying over time would raise special and important questions if their effect was to expand liability; thus, one might suppose that had the issue been presented Justice Thomas would again have been particularly interested in what the common law was on the date of enactment. Yet the tone here is quite different from those other efforts. Indeed, in a case involving hand grenades, an earlier Supreme Court opinion had directly characterized the Act as a public welfare statute, "a regulatory measure in the interest of the public safety, which may well be premised on the theory that one would hardly be surprised to learn that possession of hand grenades is not an innocent act." ${ }^{140}$ But that case was concerned with knowledge of the registration requirement, not of the character of a hand grenade; the majority's view that the possession of guns is innocent in Ameri-

\footnotetext{
${ }^{137} 114 \mathrm{~S}$ Ct at 1797.

${ }^{138}$ Discussed in text following p 429.

${ }^{139}$ Discussed in text following $\mathrm{p} 447$.

${ }^{140}$ United States $v$ Freed, 401 US 601, 609 (1971), quoted in 114 S Ct at 1799.
} 
can society-the more general proposition-thus distinguished that case, and made it permissible in these facts to invoke the more usual malum in se reasoning.

Justice Stevens's opinion draws on the legislative history of the Act, in particular, and on the special character of semiautomatic weapons, to support its conclusion that the "regulatory offense" approach is fully appropriate to Staples's case. Which of the two one finds more persuasive probably turns on the latter issue of characterization. In Justice Stevens's view, the majority "reaches the rather surprising conclusion that guns are more analogous to food stamps than to hand grenades"; ${ }^{141}$ Justice Thomas analogizes the equities to the Court's probable hesitation "to conclude on the basis of silence [in a statute attaching major penalties to violations of automobile emissions standards] that Congress intended a prison term to apply to a car owner whose vehicle's emissions levels, wholly unbeknownst to him, began to exceed legal limits between regular inspection dates." 142 For Justice Stevens, the guns in question are semiautomatic weapons that give notice of their special dangerousness and are not within American traditions of gun ownership; for Justice Thomas, that limitation cannot be constructed out of a statute that refers to "firearms" and then to the limited subclass of "machine guns." Within this framework of debate over characterization, however, Justice Thomas's opinion seems quite unlike many of his other efforts during the Term in its willingness to bring general considerations to bear on the interpretation of statutory text.

\section{CUSTIS V UNITED STATES}

In Custis $v$ United States, ${ }^{143}$ announced on the same day as BFP, ${ }^{144}$ Justice Souter's common law sensibilities and attention to the actualities of rule administration failed for the second time that day to

${ }^{141} 114 \mathrm{~S}$ Ct at 1810 (Stevens dissenting). The reference is to Liparota $v$ United States, 471 US 419 (1985), a case involving the mens rea requirement associated with food stamp offenses under a statute that, unlike the National Firearms Act (as Justice Stevens points out, id at n 15), referred to offenses committed "knowingly."

$142114 \mathrm{~S} \mathrm{Ct}$ at 1802.

${ }^{143} 114$ S Ct 1732 (1994).

${ }^{144}$ Discussed in text following $\mathrm{p}$ 449. The cases were announced May 23, 1994. Seven opinions were announced on that Monday, six of them involving at least in part the meaning of federal statutes, and splitting the Court in similar ways. 
persuade a majority of his colleagues. Section 924(e) of the Armed Career Criminal Act imposes significantly enhanced penalties for persons convicted of felonies and possessing firearms if they have "three previous convictions . . . for a violent felony or a serious drug offense." ${ }^{145}$ Custis, convicted of possessing cocaine and a firearm, had three prior state convictions for violent property offenses. The government moved to enhance his sentence under the statute. At the sentencing hearing, Custis challenged two of his prior convictions collaterally, as infected with constitutional procedural errors. The question for the Supreme Court was whether the ACCA's reference to "three previous convictions" should be understood to permit such collateral challenges.

The Chief Justice wrote for six-Justice Ginsburg now joining the $B F P$ majority - that the Act does not authorize such collateral attacks. He reasoned that "the statute focuses on the fact of conviction." 146 Another section of the statute, § 921(a)(20), detailed what convictions counted, excluding those that had been "expunged, or set aside" or had resulted in a pardon or the restoration of civil liberties. The implication of reference to convictions already set aside is that those not yet impugned may be counted. In a drug offense statute, Congress had explicitly provided for collateral challenges to prior convictions that would otherwise cause sentence enhancement. And in Lewis $v$ United States, ${ }^{147}$ the Court had held it unnecessary to permit collateral challenges to convictions on which federal prosecutors premised the felony of gun possession by one previously convicted of a felony. The Court had twice held as a constitutional matter that prior convictions could not be used for sentencing enhancement; but, the Chief Justice explained, those cases involved outright denials of the right to counsel, a "unique constitutional defect" that was "jurisdictional" in character. ${ }^{148}$ None of the flaws Custis claimed had that severity. Permitting collateral inquiry into such issues as the adequacy of representation would create practical difficulties and undermine the finality of judgments.

The first argument in Justice Souter's dissent, joined by Justices

\footnotetext{
${ }^{145} 18$ USC $\S 924(\mathrm{e})$.

${ }^{146} 114 \mathrm{~S} \mathrm{Ct}$ at 1736 (emphasis in original).

${ }^{147} 445$ US 55 (1980).

$148114 \mathrm{~S} \mathrm{Ct}$ at 1733.
} 
Stevens and Blackmun, strikes a characteristic difference in tone. For him, the starting point is that the Court's two constitutional holdings were in place when $\S 924(\mathrm{e})$ was enacted, and were uniformly understood by both commentators and the courts of appeal to require courts generally "to entertain claims that prior convictions relied upon for enhancement were unconstitutional." After the enactment of $\S 924(\mathrm{e})$, the courts of appeals uniformly understood its reference to "conviction" to mean "lawful conviction"-that is, to permit collateral challenge-yet a Congress that subsequently amended $\S 924$ with some frequency did not change its language in this respect. This more detailed view of "the contemporary legal context" within which Congress could be said and had previously been understood to have acted gave its silence about collateral challenge a different spin. Justice Souter reasoned that the legislative history of $\S 921$ (a)(20), enacted two years after $\S 924$, showed it to have been dealing with problems arising under another section; the explicit reference to collateral attack in the drug statute, enacted in 1970, provided little information about Congress's understanding in 1984, by which time the constitutional claim to collateral relief had become well established. And Lewis itself carefully distinguished the earlier collateral relief cases as involving sentencing; although "a sentence-enhancement law 'depend[s] upon the reliability of a past . . . conviction,' " Congress could rationally decide to exclude all persons who had previously been convicted of felonies from lawful gun possession as " 'a sweeping prophylaxis' designed 'to keep firearms away from potentially dangerous persons. "149 The constitutional validity of conviction was irrelevant if the statute thus served to regulate primary conduct.

Justice Souter had additional arguments in his quiver-that the statute ought to be interpreted to avoid a difficult constitutional question, ${ }^{150}$ that the feared practical difficulties had failed to emerge in the intervening years when the courts of appeals had been permitting collateral challenges. I don't wish to suggest that the reader must be persuaded by any of them. One supposes, too, that the

\footnotetext{
${ }^{149}$ Id at 1742 (Souter dissenting), quoting 445 US at $63,67$.

${ }^{150} 114 \mathrm{~S} \mathrm{Ct}$ at 1743. In particular, he deplored the reassertion of the idea of "jurisdictional" constitutional violations, one he thought had long been discredited. The distance between deprivation of one's constitutional right to counsel by utter failure to provide one and deprivation by providing one who fails to do the work is in any event not large; inadequate representation was one of Custis's claims.
} 
opinions in the case may have been influenced by the writers' attitude toward postconviction relief, a matter quite apart from judicial style. What seems worth remarking here, again, is the difference in the two opinions' stance toward Congress and the job of judges. The majority holds Congress to a standard of precision in speaking, and is relatively indifferent to the context in which it speaks-even when important elements of that context are of the courts' own making. The statutory text is an abstract given; its subsequent interpretation by the courts and the fact or absence of congressional response are not worth mention. For Justice Souter, Congress is a much more human institution, and its relations with the judiciary are to be seen as interactive and dialogic. "[T]he assumption that all omissions in legislative drafting are deliberate [is] an assumption we know to be false." ${ }^{151}$ Congress's actions and failures to act are to be set in the context of the developing law of the times; the premise here is one of shared responsibility, in which the development of judicial decision plays a significant role in assigning meaning to text and the integrative role of the judiciary is stressed.

\section{HAGEN V UTAH}

A case involving criminal jurisdiction over Native Americans provided one of the Term's most thoroughly integrative opinions for those members of the Court who-particularly in the administrative contexts we have yet to reach-were generally the most likely to avoid inquiries into legislative history, the history of law's application, and resulting expectations. In Hagen $v$ Utah, ${ }^{152}$ Utah's criminal jurisdiction over a Native American accused of a drug offense turned on whether statutes enacted in the period 1902-05 had the effect of diminishing the size of the Uintah Indian Reservation. The offense occurred on land that had been within the original boundaries of the Reservation, but that had subsequently been opened to non-Indian settlement. State criminal law could not apply to the acts of Native Americans occurring on reservation lands. The fact that the land had been opened to non-Indians was not enough in itself to establish that the reservation had been diminished. A majority of seven, Justice O'Connor writing, found that the statutes in question worked to effect a diminution, so that

\footnotetext{
${ }^{151}$ Id at 1741 .

152114 S Ct 958 (1994).
} 
Utah could prosecute the alleged crime; Justices Blackmun and Souter, invoking the checkered past of our national government's dealings with Indian tribes, could not find the "clear and unequivocal evidence of congressional intent to reduce reservation boundaries" prior cases required. ${ }^{153}$

Both opinions examined in detail the course of dealings with the Uintahs that led to the statutes in question and the records of legislative action in reaching their respective conclusions. Their disagreement over the result of this inquiry is less significant here than that both opinions undertook it. And, in contrast with the analysis often offered by Justices tending to approach statutory issues formally, Justice O'Connor credited what happened after the adoption of the statutes in question as significant for determining their meaning. She noted that the population of the apparently ceded lands was almost entirely non-Indian, that traditional Uintah administration had been limited in practice to the areas not opened for non-Indian settlement, and that Utah had regularly exercised jurisdiction over the opened lands. "This 'jurisdictional history,' as well as the current population situation ...., demonstrates a practical acknowledgment that the Reservation was diminished; a contrary conclusion would seriously disrupt the justifiable expectations of the people living in the area." 154

From a justice standpoint, it is somewhat perverse thus to credit behavior and results rooted in the exercise of superior force over exploited peoples, while leaving unexplored similar considerations arising from ordinary day-to-day administration of law. Justices Blackmun and Souter, who were usually more willing to credit such behavior with significance during the Term, made this irony explicit. ${ }^{155}$ Yet one cannot escape that the premise is one argued for in this essay; like legislative history, it did not wholly disappear from the Term's work.

\section{E. THREE HARD CASES}

As with many issues of approach to judicial function, ideas such as the primacy and stability of the original text can be overcome

\footnotetext{
${ }^{153}$ Id at 971 . The majority disagreed that a "clear statement" was required, but not that statutes must establish a congressional purpose to diminish the reservation and that doubts were to be resolved in the Indians' favor.

${ }^{154}$ Id at 970.

${ }^{155}$ Id at $971,978,980$.
} 
by other factors, such as attitudes toward crime. The varying opinions in three criminal decisions from the 1993 Term are illustrative; Justices who would ordinarily eschew indicators outside the text sometimes appear to be tempted by results its use produces. The special force of principles of lenity in criminal law, like the law's assertion of solicitude for Native American interests that might have been at work in Hagen, gives some of the Term's opinions an ironical turn.

Williamson $v$ United States ${ }^{156}$ promised to "clarify the scope of the hearsay exception for statements against penal interest." 157 (With four opinions supporting a remand for reconsideration-none fully the opinion of the Court-the Court seems to have fallen short of that worthy goal.) Rule 804(b)(3) of the Federal Rules of Evidence permits the introduction into evidence, as an exception to the hearsay rule, of self-inculpatory "statements." 158 The Court had to decide whether that provision reached past an accomplice's acknowledgement that he himself was carrying cocaine, to his saying that he was carrying it for the defendant. A majority of the courtJustices O'Connor, Scalia, Ginsburg, Blackmun, Stevens, and Souter-relied chiefly on textual materials to conclude that "statements" could not be taken to mean the whole of a suspect's conversation with authorities, but only those parts of it that were selfinculpatory. The six disagreed among themselves whether any part of the accomplice's narrative was likely genuinely to fit the latter description; only Justices O'Connor and Scalia concluded that some probably would. Striking for present purposes is that Justice Kennedy argued strongly for himself, the Chief Justice and Justice Thomas that collateral materials (in this case, primarily Advisory Committee notes) should be relied on to give the text a meaning that made it more likely that the accomplice's words could find use against the defendant's interest. Ordinarily, they deprecated the use of such materials; here, they failed as well to deal with the constitutional questions raised by broad admissibility of statements whose maker cannot be confronted.

\footnotetext{
156114 S Ct 2431 (1994).

${ }^{157}$ Id at 2433.

158 "Statement" is defined by Fed R Ev $\S 801$ as "an oral or written assertion." Justice O'Connor shows by dictionary references that the definition is unhelpfully circular ("Assertion" $\rightarrow$ "declaration" $\rightarrow$ "statement"), and then argues that "the principle behind the Rule, so far as it is discernable from the text, points clearly to the narrower meaning." Justice Kennedy's concurrence, atypically for him, does not mention the textual indicator of $\S 801$.
} 
United States $v$ Granderson ${ }^{159}$ brought the Court face-to-face with imperfections in legislative process. Granderson had been convicted of a postal offense that, under the sentencing guidelines, could have resulted in at most a six-month penitentiary term; he had been placed on probation for five years. He was shortly found in possession of cocaine, and a 1988 amendment to the criminal code required the court in such a case, after a hearing, to "revoke the sentence of probation and sentence the defendant to not less than one-third of the original sentence." ${ }^{160}$ The italicized language creates the problem. Other indicators give strong signals that Congress wanted the new sentence to require confinement. That would have been the natural result under the practice once followed in the federal courts. Before 1984, if probation was to be the court's choice, the sentencing court would first impose a penitentiary sentence and then suspend it for the probationary period. But passage of the Sentencing Reform Act in 1984, four years before the amendment in question, had ended that federal practice. Under that statute, probation is now a "sentence." There is no longer any "original sentence" other than the sentence of probation. What is "one-third of the original sentence"?

Justice Ginsburg, writing for five Justices, ${ }^{161}$ was willing to improvise with "the original sentence" to rescue the apparent sense of the legislation, while the Chief Justice and Justices Scalia, Kennedy, and Thomas, in three opinions, ${ }^{162}$ insisted on fidelity to text. Thus, glancing sideways at the size and complexity of the overall legislation, and the last-minute and largely unexplained introduction of this section as a floor amendment, the majority concluded that the statute requires at a minimum confinement for one-third of the maximum jail sentence that might initially have been imposed under the sentencing guidelines, had a jail term been chosen. In effect, they treated Congress as if it had simply forgotten the 1984 change in sentencing practice, and in 1988 had referred back to what everyone remembered sentencing practice to have been. They were willing to repair a statute that Congress had left in a state of disarray, following as best they could the indicators of

\footnotetext{
${ }^{159} 114$ S Ct 1259.

16018 USC \& 3565(a).

${ }^{161}$ Justice Ginsburg for herself and Justices Blackmun, O'Connor, Stevens, and Souter.

${ }^{162}$ Justices Kennedy and Scalia wrote individually, concurring in the result; the Chief Justice, joined by Justice Thomas, wrote in dissent.
} 
congressional purpose that could be derived from the statute and its context and measuring their success by their result-a required jail sentence, within the range that might originally have been imposed.

The four textualists insisted that "the original sentence" must refer to the sentence actually imposed, the sixty-month probation sentence, but disagreed whether the required replacement sentence was to be a minimum of 20 months in jail, or a minimum of 20 months on probation, with jail up to six months still possible on resentencing. Justices Kennedy and Scalia, separately concurring in the result, chose 20 months' probation; the Chief Justice and Justice Thomas chose a 20-month jail term. Both results are possible on the text, and both are extraordinary. One permits a significant amelioration rather than enhancement of sentence; while that amelioration can be controlled against, Congress cannot be imagined to have desired this interpretation. The other interpretation achieves sentence enhancement, but at the cost of offending legality; it requires imposition of a longer jail term, after a relatively informal hearing, than could normally have been given even after a criminal trial for drug possession followed by maximum consecutive sentences under the sentencing guidelines for the two offenses that would then have been established. ${ }^{163}$

Finally, Ratzlaf $v$ United States, Justice Ginsburg's second opinion for the Court, also for a majority of five. ${ }^{164}$ As a means (in part) of tracing money laundering, 31 USC $\$ 5313$ requires banks and other financial institutions to report transactions involving $\$ 10,000$ or more in cash. Section 5324(3) makes it illegal, "for the purpose of evading [these] reporting requirements," to "structure . . . any transaction," and $\S 5322$ (a) states the criminal penalties applicable to anyone "willfully violating" $\$ 5324(3)$ and other provisions of these reporting statutes. Ratzlaf concerned the problem of scienter under these statutes. Casino employees had driven Ratzlaf from bank to bank in Reno and Lake Tahoe to facilitate his cash purchase of $\$ 9,500$ bank checks to meet his large gambling debt to the casino. He and they plainly knew that he was structuring his transaction

\footnotetext{
${ }^{163}$ The usual maximum sentences under the guidelines would be six months for the mail offense, one year for possession of cocaine.

${ }^{164} 114 \mathrm{~S} \mathrm{Ct} 655$. Not until her fourth opinion of the Term did Justice Ginsburg succeed in attracting the concurrence of all her colleagues, although, traditionally, a new Justice's first assigned opinion has been a unanimous one.
} 
in order to avoid the reports that would have to be made if he paid the casino with the cash he at first brought them, or bought larger bank checks. But the jury was told it did not need to find he knew that this structuring was unlawful.

Justice Ginsburg was joined by Justices Stevens, Scalia, Kennedy, and Souter in concluding that "willfully violating" entailed that the government did have to make that showing. That had been the conclusion the courts of appeals had reached in prior interpretations of scienter requirements under other provisions of 31 USC referred to by $\S 5322$ (a). The majority thought people would often "structure" cash transactions for reasons other than giving some hint that they possessed cash from illegal sources-to hide it, for example, from a divorcing spouse or others who might be looking for signs of wealth. Both in its attention to general consistency and in its attention to other factual patterns proposed interpretations could affect, the majority opinion was unexceptional; arguments from text have the strongest claim in criminal cases, as it remarked, and here the text, thus illuminated, persuaded it that Congress meant to require knowledge of the unlawfulness of structuring as an element of the offense.

Justice Blackmun wrote the dissent, joined by the Chief Justice and Justices O'Connor and Thomas. With the exception of Justice Blackmun, the dissenters are among those who during the Term generally opposed the use of materials and arguments from congressional process. Yet the dissent relied on two process arguments for its conclusion that knowledge of unlawfulness need not be shown. First, it argued, $§ 5324$ was enacted after the rest of the subchapter had been in place for some years, as a direct response to private structuring of transactions to avoid the desired reporting. The amendment expresses directly the element of purpose Congress wished to capture. Knowing this history of development, the dissent argued, undercuts the claim that the umbrella phrase "willfully violating" of $\S 5322(a)$, generally applicable to the subchapter, introduced an unusual requirement of knowledge here. Second, the dissent reasoned, the legislative history indicates (as the majority virtually conceded) that Congress meant to require no more than knowledge of (and purpose to evade) the reporting requirements. The text ought to be interpreted faithfully to that history. These are, of course, quite standard arguments. What is striking is to find these three Justices, perhaps especially Justice 
Thomas, joining an opinion that relies so heavily on the context in which Congress acted, and on the political history of its particular actions, as its bases for understanding what Congress has said.

\section{Cases Implicating the Judgment of an Administrative Agency}

\section{A. DIRECTOR, OFFICE OF WORKERS' COMPENSATION PROGRAMS V} GREENWICH COLLIERIES, INC. AND HAWAIIAN AIRLINES V NORRIS

The question in Director, Office of Workers' Compensation Programs $v$ Greenwich Collieries ${ }^{165}$ was whether the Department of Labor could rule for benefit claimants, in cases arising under programs it administered, if the evidence supporting the claim was in equipoise; or, was the Department statutorily required to assign claimants the burden of ultimate persuasion (i.e., demonstration by a preponderance of the evidence). Two different programs were involved; under one, the Department had been ruling for claimants if evidence was equally balanced for more than 50 years; in the other, it had been doing so for more than 15 years. Since 1946, however, the Administrative Procedure Act has provided that "[e]xcept as otherwise provided by statute, the proponent of a rule or order has the burden of proof," 166 and no statutory provision allocated the burden of proof under either benefit program. The question for the Court was whether this concededly applicable provision precluded the Department's pro-claimant stance.

The question may not have much practical importance. Since the "preponderance" test is satisfied by the slightest differences in proof, equipoise must be an unusual outcome. And presumably the Department could find other ways to favor claimants in considering the evidence. Yet the issue is harder than a first reading of the statute might suggest. "Burden of proof," as all the Justices recognized, is an ambiguous phrase. It might mean the burden of showing that a claim is plausible-frequently referred to as the burden of production, of going forward, or of establishing a prima facie case; or, it could mean the burden of ultimate persuasion. The Court divided 6-3; its opinions again reflect the contrast between static and developmental approaches to issues of meaning, and the usual prevalence of the former.

\footnotetext{
165114 S Ct 2251 (1994).

1665 USC $§ 556(d)$.
} 
Justice O'Connor, for herself and five others, ${ }^{167}$ identified the interpretive task as "ascertain[ing] the ordinary meaning of 'burden of proof' in 1946, the year the APA was enacted"; 168 ultimately she concluded that "burden of ultimate persuasion" was what had been meant. This was not an easy intellectual process, and in it Justice O'Connor consulted a range of materials rather broader than those the more formal members of the Court usually seemed willing to consider - the understanding of "burden of proof" in the legal community, courts, and commentators in the years leading up to the APA's passage, and its legislative history before the Congress. Justice Souter's dissent for himself and Justices Stevens and Blackmun makes a reasonable argument that the majority reached the wrong result on its own premises, but for our purposes the more notable characteristic of the majority argument, in this respect, may have been its openness to sources beyond the text for understanding what Congress had done.

Several developments occurring after 1946 could be thought to bear on the section's meaning: The programs had been administered under a different understanding for years; for one of them, the Secretary plausibly claimed to have varied the APA's application by departmental rule, as the governing statute permitted. An intervening Supreme Court precedent had summarily rejected the "burden of persuasion" interpretation of $\S 7(\mathrm{c})$, remarking with supporting lower court citation that the section "determines only the burden of going forward, not the burden of persuasion."169 Other Supreme Court opinions and a significant body of precedent in the lower courts built on this understanding. The majority credited none of these developments. It characterized the departmental rule in question as general in terms; the majority did "not think this regulation can fairly be read as authorizing the Department's rule and rejecting the APA's burden of proof provision"170-a thought that neglected both the frequently expressed obligation to defer to an agency's interpretations of its own rules ${ }^{171}$ and the possibility that, at the time, the Secretary might not have thought she was "rejecting" what the APA provided.

${ }^{167}$ The Chief Justice and Justices Scalia, Kennedy, Thomas, and Ginsburg.

$168114 \mathrm{~S} \mathrm{Ct}$ at 2255.

${ }^{169}$ NLRB v Transportation Management Corp., 462 US 393, 404 n 7 (1983).

$170114 \mathrm{~S} \mathrm{Ct}$ at 2254.

${ }^{171}$ See Thomas Jefferson University $v$ Shalala, discussed in text at p 525. 
The majority also put aside the Court's own prior construction of $\S 7(c)$, despite what it acknowledged to be "the importance of adhering to precedent, particularly in a case involving statutory interpretation." 172 It deprecated the prior interpretation as a "cursory conclusion," 173 to which limited attention had been given in the briefs of that case. That conclusion also was in "tension" with a somewhat earlier Supreme Court interpretation of $\S 7$ (c) that had not mentioned the "burden of persuasion" approach but could be argued to support it by implication. ${ }^{174}$ The majority did not now ask, however, whether this "tension" had been generating practical difficulties; and there appear to have been deficiencies in the briefing in Greenwich Collieries as well as in the earlier precedent: As the dissent remarked in a note, ${ }^{175}$ none of the parties argued for overruling the Court's previous decision (one amicus did), and the lower courts had not considered that issue. Effectively conceding that the text of $\S 7$ (c) could be given either the "burden of persuasion" or the "burden of production" meaning, the only reason the majority gave for changing the law governing "burden of persuasion" in 1994 is its judgment that this is what Congress likely chose in 1946.

Justice Souter's dissent also addressed what Congress probably understood "burden of proof" to mean in 1946, but it was far more concerned with what the judiciary had done with the phrase since its adoption. The majority directly discussed only the two post1946 Supreme Court decisions mentioned above, and did so only to set forth their doctrine. The dissent invoked 28 opinions of the courts of appeals either addressing the $\S 7(\mathrm{c})$ issue or supporting the application of the Department's rule in benefits claim cases; it cited as well every major treatise on federal administrative law as uncritically accepting, indeed supportive of, the "burden of production" interpretation. And it also showed how this "burden of

${ }^{172} 114 \mathrm{~S} \mathrm{Ct}$ at 2258. Where high stakes and accompanying visibility for the Court's actions have produced strong pressures around this issue, Justice O'Connor has strongly asserted the values of stare decisis in statutory matters. Compare the discussion of Patterson, in the text at page $459 \mathrm{ff}$, and Planned Parentbood of Southeastern Pennsylvania $v$ Casey, $112 \mathrm{~S}$ Ct 2791 (1992); and see Edward H. Levi, An Introduction to Legal Reasoning 57 (1949).

$173114 \mathrm{~S} \mathrm{Ct}$ at 2257.

${ }^{174}$ Steadman $v$ SEC, 450 US 91 (1981).

${ }^{175} 114 \mathrm{~S} \mathrm{Ct}$ at $2263 \mathrm{n} 4$. Compare the discussion of Central Bank of Denver v First Interstate Bank of Denver at page 510 . 
production" understanding and acceptance of the Department's rule had worked its way into the Court's own jurisprudence in other cases not directly presenting the issue. ${ }^{176}$

If it were the highly controversial source of continuing debate, an open-and-shut question, or a matter of large practical significance, one might see a need to readdress an issue apparently put to rest on an earlier occasion; yet the Court has recently been attentive to stare decisis in such cases. ${ }^{177}$ The burden of proof issue is none of these, and that makes all the more remarkable the majority's insouciance about ripping up a fabric of understanding the Court's actions had contributed to creating. It is not evident why the considerations underlying stability in law should be less commanding as to a matter not put forward by the parties and as to which high social stakes cannot easily be identified. The question was well settled; the issue was at best debatable even in 1946; and the only negative consequence the Court suggests arising from the existing understanding is that it would leave agencies with some discretion to allocate the burden of persuasion programmatically. This was, however, discretion they had enjoyed for the preceding decades without demonstrated inconvenience or confusion, discretion that would be granted by the alternative, permissible understanding of the language Congress employed, and discretion that would have at best marginal impact on outcomes. ${ }^{178}$ The result is to underscore both the formally static quality of the Court's approach and its destabilizing potential. Fundamentally, the majority was concerned only with determining what the statute had meant in 1946. Although stare decisis might in some circumstances force the Court to swallow an intervening "error," the statute would always mean what it had meant on enactment. Common law processes could not work upon it, even within the room concededly

${ }^{176}$ Id at 2265, discussing Ward's Cove Packing Co. $v$ Antonio, 490 US 642 (1989), and Mullins Coal Co. v Director, Office of Workers' Compensation Programs, Dept. of Labor, 484 US

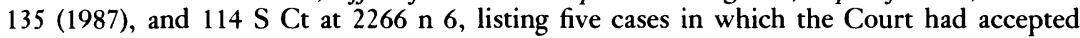
allocation of the burden of persuasion on a program-by-program basis, following "customary reference to statutory text, congressional intent, experience, policy, and relevant evidentiary probabilities."

${ }^{177}$ See note 171.

${ }^{178}$ The majority recognized that presumptions and an administrative attitude of solicitude for claimants would have the same kind of effect as the proposition that a claimant wins if, he having satisfied their burden of production, persons opposing their claim fail to persuade that it should not be granted. At 114 S Ct 2259. 
left open by its text. Understandings and structures that had grown up in the interim were irrelevant to the Court's task-what the law had effectively become, a house of cards. ${ }^{179}$

While this style was a common one during the Term, as this essay may suggest, it was not universal. On the same day as Greenwich Collieries, the Court announced a unanimous opinion reflecting much greater willingness to integrate statutory and decisional materials accumulating over time. Hawaiian Airlines $v$ Norris ${ }^{180}$ required the Court to interpret a provision of the Railway Labor Act, extended to airlines in 1936, that might have preempted state law; uncontroversially identifying the question as one of congressional intent, the Court held that it did not. To reach this conclusion, Justice Blackmun's opinion considers statutory text, legislative history, and-most importantly for these purposes-the course of judicial opinions from the time of the statute's enactment as well as the relation of this issue to like issues arising under other statutes. All this appears quite unself-conscious; and it points in a direction of a unifying test that joins the preemption issue under the RLA with a similar one that had arisen under the Labor Management Relations Act. "[T]he common purposes of the two statutes, the parallel development of RLA and LMRA pre-emption law, and the desirability of having a uniform common law of labor law pre-emption support the application of the [LMRA] standard in RLA cases as well." 181

One could hardly imagine a stronger contrast with Greenwich Collieries. Pre-emption is a question of congressional intent, but here one finds no suggestion that the issue was fixed as of the RLA's enactment (or its 1936 extension to airlines); the Court accepts as consistent with its idea that pre-emption is a matter for legislative determination, the idea that a test articulated under a different, later statute is the right one to apply here. It does not require any evidence of congressional action on, or even thought about, its application to the RLA. The appropriateness of the courts' creating

\footnotetext{
${ }^{179}$ For a recent, somewhat more theoretically inclined approach to these issues, see William N. Eskridge, Jr., Post-Enactment Legislative Signals, 57 L \& Contemp Probs 75 (1994).

${ }^{180} 114 \mathrm{~S}$ Ct 2239.

${ }^{181}$ Id at $2249 \mathrm{n} 9$; to somewhat similar effect, see the Court's unanimous opinion in Lividas

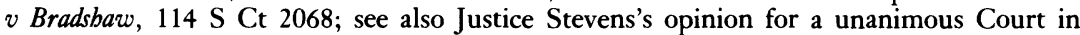
McDermott $v$ Amclyde, 114 S Ct 1461, a strictly common law matter.
} 
a "unified system of judge-made and statute law . . . by the processes of adjudication" 182 is simply assumed.

The tendency of this approach, as Justice Stone well recognized, is to promote coherence in law, to induce stability in its administration, to reward expectations, to discourage dispute. To see where the Greenwich Collieries approach might lead, consider the issue of standing to challenge administrative actions. This APA issue is more controversial than "burden of proof"; it is one where the Court's "error" in departing from 1946 understandings is more readily shown; and it is one that has larger consequences. Section 10(a) of the APA ${ }^{183}$ provided that "A person suffering legal wrong because of agency action, or adversely affected or aggrieved by agency action within the meaning of a relevant statute, is entitled to judicial review thereof." In 1970, the Supreme Court interpreted the italicized language as itself conferring standing on persons concretely injured by agency action, so long as the injury could reasonably be thought one the underlying statute was concerned to avoid. ${ }^{184}$ The language can support the 1970 interpretation; that interpretation is strongly consonant with administrative law developments of the late 1960's and following that emphasized participatory values in administrative process and, in particular, greatly expanded the claims of those who were the intended beneficiaries (rather than the intended subjects) of regulation to have a part in administrative action at all levels. This judicial development was both $\operatorname{led}^{185}$ and kept in check ${ }^{186}$ by the Court; its general course doubtless helps to explain why the APA has not been significantly amended in the almost half century since its enactment. The judiciary has kept the APA more or less in step with developing understandings, as it has the Constitution and other important texts of general law.

If what Congress would have understood in 1946 controls, the

\footnotetext{
182 Stone, note 8.

1835 USC 702.

${ }^{184}$ Association of Data Processing Service Organizations v Camp, 397 US 150 (1970). From this perspective, the case adopted for APA review a public law rather than a common law model of standing, in the interesting terms suggested in Cass R. Sunstein, Standing Injuries, 1993 Supreme Court Review 37, 53-62. Sunstein generally criticizes ADAPSO for its misleading focus on "injury" as if that were independent of law.

${ }^{185}$ For example, in addition to ADAPSO, Abbott Laboratories v Gardner, 387 US 136 (1967), and Citizens to Preserve Overton Park $v$ Volpe, 401 US 402 (1971).

${ }^{186}$ Vermont Yankee Nuclear Power Corp. $v$ NRDC, 435 US 519 (1978).
} 
contemporary interpretation of $\S 10(\mathrm{a})$ is more clearly in error than the Department of Labor approach challenged in Greenwich Collieries. ${ }^{187}$ Where the ambiguity of "burden of proof" was well known in 1946, no one was asserting a doctrine of generalized standing to challenge agency actions for citizens intended to have been benefited by regulation and concretely injured by some failure of effort on an agency's part. Rather, Congress had passed a few particular statutes for the prominent agencies that explicitly provided participatory rights to persons who would be adversely affected or aggrieved by agency action, and these provisions had been held to authorize those persons to seek judicial review of agency outcomes that harmed their interests. ${ }^{188}$ As it would have been understood in 1946, $\S 10$ (a) incorporated-ratified-this approach to statutes with "adversely affected or aggrieved" provisions in them. Had a general, undiscriminating grant been intended, one would expect to find it articulated and debated; those debates are not to be found, ${ }^{189}$ and it took a quarter century, until 1970, for that interpretation to emerge. If Congress's likely understanding in 1946 of the words it employed is entitled to prevail, the following quarter century's development in administrative law-now on a matter of large significance-is in the balance.

This Court is deeply concerned with standing issues, a majority approaching them with a sensibility suggesting they would be happy for the chance to retrench. ${ }^{190}$ Is that what Greenwich Collieries promises? Perhaps some or all signers of the majority opinion would find, in the standing context, that correcting the Court's earlier error in discerning what $\S 10$ (a) had meant in 1946 would have so large an effect on the general fabric of the law that stare decisis considerations would control. But even that way of putting

${ }^{187}$ The reader is entitled to know that my name was on the government's brief in ADAPSO, and that I argued the companion case of Barlow $v$ Collins, 397 US 159 (1970) for the government; the government opposed standing in both cases. In my judgment, the Court did not act impermissibly in 1970, although it abandoned 1946 meaning; while it follows that the 1970 meaning, too, has no claim to permanence, change must be grounded in the general law and circumstances of 1994, not those of 1946.

${ }^{188}$ See Associated Industries of New York State v Ickes, 134 F2d 694 (2d Cir 1943).

189 See The Attorney General's Manual on the Administrative Procedure Act 96 (1947).

${ }^{190}$ See Justice O'Connor's in-chambers opinion granting a stay in anticipation of a denial of standing in INS $v$ Legalization Assistance Project, 114 S Ct 422 (1993); see also Lujan v Defenders of Wildlife, 112 S Ct 2130 (1992); Cass R. Sunstein, Wbat's Standing After Lujan, 91 Mich L Rev 163 (1992). 
it suggests a significant difference in stance from opinions like $\mathrm{Ha}$ waiian Airlines. It would be accompanied by expressions of regret and acceptance rather than affirmation of a judicial choice among possible meanings that had been shaped by intervening changes in law, accepted over time by Congress and by the people. ${ }^{191}$ The Court in 1970 did not seem to imagine the APA as forever tied to 1946, until a later Congress was motivated to change it. The language Congress had used could be read and interpreted in 1970, within the general framework of law as it had developed to that point and was developing. One Court acts as Congress's partner and in the framework of development familiar to the common law; for the other, judicial development is illegitimate and statutes are fixed, static events.

\section{B. MCI TELECOMMUNICATIONS CORP. V AMERICAN TELEPHONE AND TELEGRAPH CO. AND NORTHWEST AIRLINES, INC. V COUNTY OF KENT, MICHIGAN}

In 1934, when the technological constraints imposed by wire transmission of telephone conversations gave AT\&T a natural monopoly of interstate transmission, Congress enacted 47 USC $\S 203$, requiring the FCC to regulate interstate telephone rates; the same section permitted the Commission "in its discretion and for good cause shown, [to] modify any requirement" (emphasis added) of the section imposing this requirement, except that it could not impose a longer than 120 day notice period on carriers seeking rate changes. By the 1970s, the development of microwave and satellite technologies permitted competition in interstate telephone services to develop. The same period found many economists and others vigorously criticizing rate regulation in general as an often inefficient regulatory technique, one that served to create barriers to entry into otherwise competitive markets and in other ways to keep the rates the public was charged for services above, rather than below, what they would naturally be in an unregulated market. The legal environment, as well, showed a strong deregulatory trend. Responding to these developments, the FCC used public rule making gradually to relax and then to eliminate rate-filing requirements for AT\&T's new competitors (the "non-dominant

${ }^{191}$ Compare the discussion of Patterson, in text at page $459 \mathrm{ff}$. 
carriers"). In doing so, it relied on its statutory authority to "modify" rate regulation requirements. Congress, sharply cutting back on rate regulation elsewhere in national regulation, did not alter the Commission's statutory mandate.

MCI Telecommunications Corp. $v$ American Telephone and Telegraph Co. ${ }^{192}$ required the Court to decide whether the FCC's action was within its authority. The thrust of Justice Scalia's opinion for five members ${ }^{193}$ of the Court was that "modify" does not permit changes as large as these; Justice Stevens wrote for three ${ }^{194}$ in dissent. The opinions were in one respect a duel over the use of dictionaries; in another, a dispute over the application of the Court's influential opinion in Chevron, U.S.A., Inc. $v$ Natural Resources Defense Council, Inc. ${ }^{195}$ describing the courts' appropriate relationship to agency gap-filling on questions of law unresolved by statute.

The dictionary duel, easily caricatured, was in some respects the Term's textualist apogee. ${ }^{196}$ For Justice Scalia, "modify" necessarily connoted incrementalism, not major change, and he supported this conclusion with dictionary evidence. The making of minor changes, without radical transformation, was a meaning dictionaries universally attached to the term. While one major dictionary had recently also included among its possible definitions "to make a basic or important change in," he regarded that inclusionrendering "modify" a synonym of "change" - as unpersuasive, one that served to make the word more ambiguous than it had previously been. Justice Stevens expressed doubt whether dictionaries should be permitted to "substitute for close analysis of what words mean as used in a particular statutory context"; ${ }^{197}$ he argued that in the larger context the Commission's changes were only incremental. Since rate filing would still characterize the bulk of interstate tariffs, those of the dominant carrier AT\&T, the general pur-

\footnotetext{
192114 S Ct 2223.

193 The Chief Justice and Justices Kennedy, Thomas, and Ginsburg; Justice O'Connor did not participate.

${ }^{194}$ Also Justices Blackmun and Souter.

195467 US 837 (1984).

${ }^{196}$ See, e.g., Pierce, cited in note 46, which well illustrates the destabilizing potential; A. Raymond Randolph, Dictionaries, Plain Meaning, and Context in Statutory Interpretation, 17 Harv J L \& Pub Pol 71 (1994), suggests the limits.

$197114 \mathrm{~S} \mathrm{Ct}$ at 2236.
} 
pose and effect of the statute would remain intact. And he pointed out that the FCC's action fit well the earliest and still primary dictionary meaning of "modify," to limit or reduce in extent or degree. Dictionaries consistently list the "minor change" sense Justice Scalia relied on after definitions suggesting limitation or reduction. Justice Scalia's opinion in MCI does not appear as committed as Justice O'Connor's in Greenwich Collieries to the position that only direct congressional action can change the meaning of statutes. When Justice Scalia refers to dictionary definitions current when the provision became law in 1934, he calls it "perhaps gilding the lily" but "the most relevant time for determining a statutory term's meaning"; 198 "large change" was not in the dictionaries then (although the primary sense of limiting or ameliorating was). Later he considers and rejects the proposition that subsequent legislative changes may have signaled congressional approval of the FCC's position; finding those changes mixed in their implication, he argues that

We have here not a consistent history of legislation to which one or the other interpretation of the Act is essential; but rather two pieces of legislation to which first one, and then the other interpretation of the Act is more congenial. That is not enough to change anything. ${ }^{199}$

"Most relevant" is different from "only"; willingness to consider a consistent subsequent history implies acceptance that meaning could change without direct amendment. Yet that change would have to be ascribable to Congress in some sense; neither the agency's nor the court's sense of developing social and economic circumstances, and the supervening structure of law, would authorize a departure from the 1934 understanding.

Perhaps the root issue for Justice Scalia is one of delegation-a factor that has been important to him in other contexts. ${ }^{200}$ It is not merely the largeness of the change being effected, but also that accepting it will entail accepting that an agency can be empowered to change its mandate. For Justice Stevens, author of striking passages in Chevron strongly endorsing delegation, ${ }^{201}$ the FCC has "un-

\footnotetext{
${ }^{198}$ Id at 2230.

${ }^{199}$ Id at 2233.

${ }^{200}$ Mistretta $v$ United States, 488 US 361, 413-27 (1989) (Scalia dissenting).

${ }^{201} 467$ US at 843-44 (1984).
} 
usually broad discretion to meet new and unanticipated problems in order to fulfill its sweeping mandate"; ${ }^{202}$ this power to "modify" is no different in kind from the Commission's responsibility to allocate licenses and otherwise act in accordance with "public convenience, interest, or necessity." 203 Justice Scalia accepts broad delegations only because he cannot imagine a judicially manageable standard for telling the good from the bad, ${ }^{204}$ a handicap he does not face if he can plausibly construe an agency's authority in a narrow way. It is revealing in this respect that he never explains how he concludes that the New Deal Congress that so broadly empowered all the agencies it created, not just the FCC, intended here only a narrow grant of authority.

The result, in any event, is essentially formal and text-bound. Whether the FCC has rightly caught the implications of new market conditions and adapted its regulatory regime to them are not issues for the Court. "[O]ur estimations, and the Commission's estimations, of desirable policy cannot alter the meaning of the Federal Communications Act of 1934. . . . [A] whole new regime of regulation (or of free-market competition) . . . may well be a better regime but is not the one that Congress established." 205 Of course, the validity of the "but is not" clause depends on one's conclusions about the meaning of "modify," one's general estimation of the breadth of authority Congress bestowed on the Commission, and also on one's acceptance or not of agency and/or judicial authority to follow Congress's lead by using existing text to adapt law to changing circumstances. In its way, the change worked by the FCC is no different from what the Court accomplished in $\mathrm{Ha}$ waiian Airlines. Looking to the general climate of change, in regulation and in technology, it is hard to imagine that the FCC erred. The general trend of legislation, the absence of any legislative effort to correct the Commission, indeed the Commission's dogged persistence in its deregulatory course despite prior discouragement from the courts-all suggest that this was the right reading. It was one that both ancient and contemporary understandings of "modify" would permit. The insistence that Congress unmistak-

\footnotetext{
$202114 \mathrm{~S} \mathrm{Ct}$ at 2234.

${ }^{203}$ Id at 2239 n 7.

${ }^{204}$ Mistretta, cited in note 200,488 US at $415 \mathrm{ff}$.

${ }^{205} 114 \mathrm{~S}$ Ct at 2233.
} 
ably act tends, again, to deny the coherence-building judicial function.

Northwest Airlines, Inc. $v$ County of Kent, Michigan ${ }^{206}$ provides a contrast with $M C I$ that is not as strong as that between Greenwich Collieries and Hawaiian Airlines, but that is nonetheless suggestive. The case concerned the legality of airport user fees under both a federal statute, the Anti-Head Tax Act, ${ }^{207}$ and the Commerce Clause of the United States Constitution. The AHTA flatly forbids states and their subdivisions from taxing persons traveling in air commerce, their carriage, or the gross receipts derived from the sale of air transportation; but as explicitly permits other forms of tax, such as property or net income tax, and, of particular importance to this litigation, also permits "collecting reasonable rental charges, landing fees, and other service charges from aircraft operators for the use of airport facilities." The issue the parties presented was the application of this permission to particular use charges imposed on commercial aviation by a Michigan airport; Justice Ginsburg concluded for all but Justice Thomas ${ }^{208}$ that, applying a judicial test developed in the Commerce Clause context, the fees were "reasonable."

The contrast with $M C I$ is provided by the possibility that an agency - in this case, the Department of Transportation's Federal Aviation Administration-might initially have assessed whether the fees were reasonable or not. The airlines challenging the reasonableness of Kent's charges might have initiated an action before the FAA, but did not, choosing instead to invoke a private right of action in district court. The Court might have decided that no such right of action was to be implied from the AHTA; but that question was not jurisdictional, the Court ruled, and the posture of the case made it otherwise unavailable. Similarly, the Court might have decided that the doctrine of primary jurisdiction required the district court to have referred the matter to the FAA for decision; again, the parties had failed to raise this issue. ${ }^{209}$ In bypassing the second of these issues, the Court signaled its preference for

\footnotetext{
${ }^{206} 114 \mathrm{~S}$ Ct 855.

${ }^{207} 49$ USC App $§ 1513$.

${ }^{208}$ Justice Blackmun did not participate.

${ }^{209}$ See New England Legal Foundation v Massacbusetts Port Autbority, 883 F2d 157 (1st Cir 1989), cited by the Court, 114 S Ct at 863 n 11.
} 
administrative treatment-recognizing that courts "are scarcely equipped to oversee [such questions] without the initial superintendence of a regulatory agency," reciting the advantages of national administration, and promising Chevron deference "[i]f we had the benefit of the Secretary's reasoned decision." This strongly voiced preference to have an agency give initial voice to what is "reasonable" and promise of deference to its views-perhaps the most forceful Chevron statement of the Term ${ }^{210}$ - contrasts with the Court's refusal to accept agency views of the undefined "modify" in $M C I .{ }^{211}$

That contrast is underscored by Justice Thomas's lone dissent; he argued that "reasonable" failed to set a judicially administrable standard under the statute, so that the permissibility or not of the exactions in question could be decided only under the dormant Commerce Clause-an issue not developed in the case, and so requiring remand. ${ }^{212}$ In its insistence that Congress create an administrable standard other than the "common law" standard the Court had developed under the dormant Commerce Clause, his opinion appears to reflect delegation concerns such as also seem to underlie $M C I$; it is hard for him to imagine "such unbridled discretion" for the Secretary. ${ }^{213}$ Again, we see that, for him, what judges can do as a matter of their separately judicial capacity appears to be quite different from, and also completely isolated from, what they may do in the administration of statutes. If this is not a concern for the Justices of the MCI majority, perhaps that is because "modify" can be cabined in ways "reasonable" cannot; ${ }^{214}$ or because the authority to say what is "reasonable" or not, however broad, is not authority to define one's own scope of regulation and so does raise delegation concerns in the same way. The Court's recognition

\footnotetext{
210 See Merrill, cited in note 41.

${ }^{211}$ And also the agency views in the next discussed case, City of Cbicago $v$ Envirnomental Defense Fund, 114 S Ct 1588 (1994).

${ }^{212}$ Justice Thomas's argument in part reflected the origin of the AHTA in congressional disapproval of a Supreme Court opinion-the source of many of the statutes interpreted in the cases discussed in this essay. Neither he nor his colleagues, in this case, directed attention to the political or administrative history of the statute as an indicator of meaning, however.

${ }^{213} 114 \mathrm{~S} \mathrm{Ct}$ at 870 (Thomas dissenting). Compare Justice Thomas's unwillingness to accept a vague regulation as establishing law in Thomas Jefferson University $v$ Shalala, discussed at p 526.

${ }^{214}$ See Antonin Scalia, Judicial Deference to Administrative Interpretations of Law, 1989 Duke L J 511, 521; cf Harris $v$ Forklift, discussed in note 71 .
} 
of potential partnership and of the agency's responsibility nonetheless stands in some contrast with $M C I$.

\section{CITY OF CHICAGO V ENVIRONMENTAL DEFENSE FUND}

City of Chicago v Environmental Defense Fund ${ }^{215}$ required interpretation of an amendment to a complex statute made in response to issues that had arisen in the course of its administration. The amendment had been promptly understood in a particular way by the agency responsible for the statute, a consideration that in the past has often been regarded as probative by courts attempting to decide for themselves questions of statutory meaning. In this case, however, the Court took a textualist view that essentially ignored the implications of political history and administrative signaling for judicial understanding.

The Resource Conservation and Recovery Act of 1976 (RCRA) created a much more stringent regulatory scheme for "hazardous" than for "nonhazardous" wastes. Those who generate hazardous waste are subject to handling, record-keeping, storage, and monitoring requirements; $;^{216}$ the owners and operators of hazardous waste treatment, storage, and disposal facilities (TSDFs) are subject to considerably more stringent regulation. ${ }^{217}$ RCRA does not itself identify which wastes are "hazardous," but authorizes the Environmental Protection Administration to do so by regulation. ${ }^{218}$ Since 1980 , EPA's regulations have provided that household waste and the residues of its incineration in power generation plants are not "hazardous wastes," even though a small portion of that waste stream (such as discarded batteries) would ordinarily be regarded as hazardous waste and even though the ash resulting from incineration, as a result, might if tested have met the ordinary definitions of "hazardous waste." ${ }^{19}$ About 150 cities have been availing themselves of this exemption, including Chicago; Chicago's municipal incinerator gener-

\footnotetext{
215114 S Ct 1588 (1994).

${ }^{216}$ See 42 USC $\S 6922 ; 40$ CFR pt 262 (1993).

${ }^{217} 42$ USC $\S \S 6924-25,40$ CFR pt 264 (1993).

${ }^{218}$ Hazardous wastes are regulated under Schedule C of the Act, 42 USC $\$ \S 6921-34$, nonhazardous wastes under Schedule D, 42 USC $\$ \S 6941-49$; EPA's authority to designate matters as hazardous or not appears in 42 USC $\$ 6921(\mathrm{a})$.

${ }^{219} 40$ CFR 261.4(b)(1). If, for example, lead or cadmium batteries formed part of the household waste stream, the lead or cadmium content of incinerator ash might exceed the EPA standards of concentration and solubility.
} 
ates over 100,000 tons of ash annually, which it has been disposing of at landfills not licensed to receive hazardous wastes.

The 1980 regulation, however, did not exempt incinerator ash from household waste if (1) the incinerator also processed any industrial waste, and (2) the resulting ash met the usual tests of hazardousness. The exemption could be withheld even if all the added industrial waste itself was not "hazardous." 220 This created a somewhat anomalous situation, since the ash from a mixture of household waste and nonhazardous industrial waste would presumably be more dilute than ash from the household waste alone. In 1984, Congress amended RCRA by adding $\S 3001(\mathrm{i}) .{ }^{221}$ Entitled the "clarification of household waste exclusion," $\S 3001(\mathrm{i})$ provided that "a resource recovery facility recovering energy from the mass burning of municipal solid waste shall not be deemed to be treating, storing, disposing of, or otherwise managing hazardous wastes" even if, inter alia, it also burns "solid waste from commercial or industrial sources that does not contain hazardous waste" (emphasis added). EPA interpreted the new provision to ratify its regulation and eliminate the possible anomaly; thus, addition of nonhazardous industrial waste to the household waste stream would not threaten the "nonhazardous" characterization of the resulting ash, whatever its actual chemical content. The Chicago incinerator now includes some nonhazardous commercial waste in its operations.

In 1988, the Environmental Defense Fund brought a citizen's action under RCRA alleging that Chicago was in violation of its obligations respecting the "hazardous waste" it was generating. The city asserted its exemption under the EPA regulation and subsequent statute, and EPA supported the city's view. If "hazardous" means bazardous, the exemption Chicago relied upon is not very attractive. To be sure, the degree of hazard presented by municipal incinerator ash may be slight compared to more concentrated sources; further, mixing in ash from nonhazardous industrial sources will dilute the household waste product. Nonetheless, hazards are being generated. And one imagines that the legislative exemption for municipal facilities had its source in politics and the

\footnotetext{
${ }^{220}$ Whether this actually happened is doubtful. The Court was informed that that EPA has "never contended that the acceptance of nonhazardous commercial waste subjected any of [the facilities] to regulation." $114 \mathrm{~S} \mathrm{Ct}$ at $1598 \mathrm{n} 10$ (Stevens dissenting).

${ }^{221} 42$ USC § 6921(i).
} 
realities of municipal economics, rather than scientific judgment about comparative risk. The question for the Court was whether, contrary to EPA's views, Chicago's waste was subject to hazardous waste regulation to any degree.

Justice Scalia wrote for seven Justices, all but Justices Stevens and O'Connor, finding that Chicago must be regulated as a generator if its ash met the physical standards for "hazardous waste," although not as a TSDF. Central to his analysis was the conjunction of four textual observations: first, hazardous and nonhazardous wastes are sharply distinguished in RCRA, with elaborate attention paid to protection of the environment from the ultimate disposition of the former; second, regulation of hazardous wastes and regulation of those who may come in contact with them are distinct subjects, and $\S$ 3001(i)'s exemption is directed to the facility producing the ash and not to the ash itself; third, those who merely generate hazardous waste are subject to much less stringent regulation under RCRA than those who subsequently "treat[], stor[e], dispose[e] of, or otherwise manag[e]" it; and, finally, the text of the 1984 amendment omits the word "generation." One can then construct a rational legislative judgment: municipal incinerators should be relieved of the stringent regulation attaching to those who "treat[, etc.,]" but since their processes may generate what is in fact "hazardous waste," the incinerators are subject to the less stringent regulatory regime governing generators and-most important - the ash they produce, if it has the physical characteristics of "hazardous waste," must be disposed of in hazardous waste facilities.

Considered independently of the amendment's political and administrative history, this is a credible, integrated reading of its text. The statute's dominating purpose to protect the public from the long-term consequences of carelessness in handling materials that threaten the environment is advanced, not merely acknowledged, by a reading that treats $\S 3001$ (i) as speaking to how Chicago is to be regulated under the law, rather than how the ash it produces shall be. Justice Stevens's response to the argument at this textual level was plausible, but not commanding: "Clarification of hazardous waste exclusion," the amendment's title, is directed to the exclusion of materials from the category "hazardous waste," not to the exclusion of processors from being regulated. Moreover, Chicago could be "generating" hazardous waste only if its municipal waste stream is not hazardous; but as a description of the physical 
sitation, if the ash is hazardous, so must the predecessor waste stream be. Finally, reading that Chicago is not to be treated as "disposing of, or otherwise managing hazardous wastes for the purposes of regulation," recipients of the ash would normally conclude they had not received "hazardous wastes." "[I]f we are to be guided only by the literal meaning of the statutory text," Justice Stevens wrote, "we must either give effect to the broad definition of hazardous waste generation and subject all municipal incinerators that generate hazardous ash to [the more stringent forms of] regulation (including those that burn pure household waste) or give effect to the exclusion that applies equally to pure household waste and mixtures that include other nonhazardous wastes." 222 On the text alone, however, and with an eye to the larger purpose of the statute, this does not seem an untoward result. Incinerators that produce physically hazardous ash will be responsible to see that it is handled by persons capable of doing so.

However strong the majority's reading might be as a construction of $\S 3001(\mathrm{i})$ in the abstract, it bore no resemblance to the administration RCRA had received from the outset, well before its 1984 amendment by $\S 3001$ (i), to the expectations expressed (and natural to suppose) at the time of that amendment, or to the treatment it had subsequently received. Justice Scalia was uninterested, however, whether his was the actual legislative judgment Congress had reached in a political sense:

The plain meaning of this language is that ... the facility[] is not subject to [the more extensive] regulation as a facility that treats, stores, disposes of, or manages hazardous waste. The provision quite clearly does not contain any exclusion for the ash itself. ${ }^{223}$

While a Senate committee report, the only available legislative evidence as to meaning, had described the exemption in terms that explicitly included "generation," 224 that language was missing from the statute.

[I]t is the statute, and not the Committee Report, which is the authoritative expression of the law, and the statute prominently

\footnotetext{
$222114 \mathrm{~S}$ Ct at 1598.

${ }^{223}$ Id at 1591 .

${ }^{224} \mathrm{~S}$ Rep No 98-284, p 61 (1983), cited at 1593.
} 
omits reference to generation. . . . The incineration here is exempt from [the more stringent form of] regulation, but subject to regulation as hazardous waste generation. ${ }^{225}$

It was irrelevant that EPA had consistently excused these municipal facilities and their ash stream from hazardous waste regulation, before as well as after the 1984 amendments; or that the amendment's history reflects not disapproval of that practice but rather (as its title suggests) the purpose to clarify and extend the exception EPA had developed. Whatever the regulation had been, the statutory text now exempted the cities only from TSDF regulation; if their ash met the physical standards, they were now generators of "hazardous waste"-whether or not they mixed nonhazardous commercial waste into their waste streams. In effect, Justice Scalia reasoned, the amendment disapproved the EPA regulation. ${ }^{226}$ Any thought of deference to EPA's interpretation fell before the observation that "the most reliable guide for [reconciling the diverse purposes of legislation] is the enacted text. Here that requires us to reject the Solicitor General's plea for deference to the EPA's interpretation, which goes beyond the scope of whatever ambiguity $\S 3001$ (i) contains."227

While it is tempting to discuss here the misleading treatment the legislative history had in the majority's hands, ${ }^{228}$ the opinion's ma-

${ }^{225}$ Id at 1593.

${ }^{226}$ Id. The EPA history was dismissed in a footnote reserving "opinion as to the validity of EPA's household waste generation regulation as applied to resource recovery facilities before the effective date of $\S 3001$ (i)." Id at $n 4$.

${ }^{227}$ Id at 1594. See Antonin Scalia, Judicial Deference to Administrative Interpretations of Law, 1989 Duke L J 511, 521.

${ }^{228}$ In the only explanation of $\$ 3001$ (i) available to Congress, the Senate Committee Report had used the word "generation," that was not to be found in the statute. S Rep No 98-284, p 61 (1983), cited at 1593. The majority wrote as if the question about legislative history were whether the single mention of the word in the report could, in the abstract, make up for its absence from the statutory text. As in Shannon $v$ United States, discussed at page 471, one would agree that it could not; but, also as there, the argument is a straw person. The argument from the legislative history is that the statute had been receiving a certain interpretation-established, known, relied upon by 150 cities that might be affected by the amendment. Were there indications that anyone thought Congress might be moving to increase EPA's regulation of municipal incinerators and their waste streams-a matter one might suppose would draw fire-much less that that was an announced purpose of the changes? Justice Stevens's argument is that what is in the legislative history, like the name Congress "significantly" attached to its action, "Clarification of household waste exclusion," confirms that its members had expansion rather than retraction of the existing exemption in view. "A commonsense reading of the statutory text in light of the Committee Report and against the background of the 1980 regulation reveals an obvious purpose to preserve, not to change, the existing rule. The majority's refusal to attach significance to 'a single word in a committee report' reveals either a misunderstanding of, or a lack of respect for, the 
jor significance for the predictability and stability of law in an administrative state, in my judgment, lies in its withdrawal of attention from the elements of continuity and responsibility in regulatory regimes-in Justice Scalia's attitude toward the history over time of RCRA's provisions and EPA's administration of them. Over half a century ago, and in the same breath as it described the interpretation of statutes in justiciable controversies "[a]s exclusively a judicial function," the Supreme Court recognized in United States $v$ American Trucking Association ${ }^{229}$ at least three conventional reasons for a court to consider a responsible agency's interpretations in reaching its own conclusions about meaning:

in any case such interpretations are entitled to great weight. This is peculiarly true ... where the interpretations involve "contemporaneous construction of a statute by the men charged with the responsibility of setting its machinery in motion, of making the parts work efficiently and smoothly while they are yet untried and new." Furthermore, . . . [agency] interpretation gains much persuasiveness [if it is] the fact that it was the [agency] which suggested the provisions' enactment to Congress. ${ }^{230}$

That is, as of 1940, three propositions were well established: First, the agency is an expert reader of its statute and consequently its reading is some evidence of what Congress did. Second, when the agency is a prompt reader as well, the likelihood that it has understood Congress is increased; the absence of an immediate challenge or controversy both confirms that belief and contributes to establishing community expectations about legal requirements, enhancing "efficient[] and smooth[]" implementation. Finally, as a participant in the drafting process (and the subject of oversight discipline as well), an agency is well placed to know what legislation is to achieve. Note that the American Trucking Association Court's focus here was on accurate judicial interpretation, not on reasons why a court has to accept an agency's reading of an ambiguous statute once it has concluded that its meaning is not clear (Chevron's "step

function of legislative committees. . . . What makes the Report significant is not the single word 'generation,' but the unmistakable intent to maintain an existing rule of law." $114 \mathrm{~S}$ $\mathrm{Ct}$ at 1597 and $\mathrm{n} 7$ (emphasis supplied; the last two sentences quoted are from a footnote appended to the first sentence quoted). Compare SEC $v$ Collier, 76 F2d 939 (2d Cir 1935) (L. Hand, J).

229310 US 534 (1940).

${ }^{230}$ Id at 549. 
two"). Like other elements of the political process that can help a court form a context in which to understand the language Congress employed, these considerations are elements that enter into the court's own initial assessment of the statute, numbered among the "traditional tools of statutory interpretation" 231 a court is to deploy at Chevron's step one. In abandoning these aids to its own interpretation of that text, in my judgment, the Court significantly undercut the general stability of law.

Such an accusation warrants a few paragraphs' further explication, which should begin by acknowledging that change and stability are both ends of the law. Judicial administration of law must always mediate the threat that interpretations, of necessity backward-looking, will defeat expectations engendered before they occur. As law and legal institutions have become more prolix and more complex over time, however, the point at which the courts will finally speak has been delayed, and the possibility of ultimate judicial resolution has become much more remote. ${ }^{232}$ Expectations will have been generated, and people will have had to act, without waiting on the courts. The courts have developed a variety of means for encouraging and maintaining expectation. While textualist approaches are supported in just these terms, the questions of responsibility these developments raise and their implications, as in City of Chicago, have not been clearly faced.

Within the traditional framework of common law, understanding the importance of reliance on current understandings has made courts chary of overrulings or even sudden departures from received traditions of analysis. Changes are constructed out of movements and trends already in place; few new rules or overrulings occur which counsel could not see looming in possibility. Statutes present harder issues in this respect-they do not have their source

${ }^{231}$ Chevron, 467 US at $843 \mathrm{n} 9$; see in this respect the Court's well-regarded opinion in Skidmore $v$ Swift \& Co., 323 US 134 (1944), detailing the elements of agency interpretation that, "while not controlling upon the courts by reason of their authority, do constitute a body of experience and informed judgment to which courts and litigants may properly resort for guidance." Id at 140 (emphasis added). The resort by litigants-that is, by members of the public-occurs early in a process that may never reach the judiciary; it is encouraged by Congress, and tends to produce uniformity and acceptance of sensible administration. Justice Jackson's invocation of this reliance in Skidmore was hardly accidental or incidental, but a reaffirmation of the designedly central role of agencies in statutes under administration.

${ }^{232}$ See Peter L. Strauss, One Hundred Fifty Cases Per Year: Some Implications of the Supreme Court's Limited Resources for Judicial Review of Agency Action, 87 Colum L Rev 1093 (1987). 
in judicial reasoning, and often enough have been passed in reaction to rather than support of judicial development of law. The challenge for the courts, seemingly met in the first half of this century, was to transcend a resulting sense of struggle with the legislatures and find means of interpretation that tended to correspond with expectations induced by the fact of passage. Courts were not interpreting statutes in the abstract, but in the midst of continuing growth and change in a legal community with ends in view and expectations about the results being produced. Putting aside for the moment the reasonable arguments that can be made of how well the legislative history tools developed for achieving these ends can still succeed in the face of changes in the legislative process, one can see how judicial attention to the political context as well as the text of legislation will have an effect similar to attention to precedent in the common law context, in bringing judicial decisions into line with social and professional expectations about what statutory text means. ${ }^{233}$

The administrative agency is in many respects a competitor with the courts in the formation both of public policy, and of public and professional expectations about law's course. Often enough, assignment of matters to administrative agencies amounts to a declaration of distrust in the judiciary's ability or disposition to manage the work entailed. As a practical matter, their creation means that citizens and lawyers look to agencies in the first instance for their understanding of law's demands. Judicial speaking to the same issues is significantly postponed-they must run the agency gauntlet first. People must arrange their affairs-decide, for example, whether to construct a municipal incinerator-and cannot afford to wait the five years or more it may require to get a judicial reading. The system of law requires some general confidence that ultimate judicial results will match the expectations generated today, on the basis of which such plans are, as they must be, made. Promoting that reliance is, itself, a part of the legislative scheme. And one can see without difficulty how elements such as the Court identified in American Trucking Association contribute to that continuity-they tend to match judicial outcomes to the predictable expectations of the community subject to the agency's jurisdiction.

${ }^{233}$ The argument is intended to concede that text is the primary source of understanding, but not that text should be read in ignorance of its provenance. 
They accommodate the courts to the agency's presence and contribution, just as attention to political history accommodated courts to the emergence of statutes as the dominant mode of law creation. A judiciary that refuses to educate itself in the historical, political, and administrative context from which it emerged invites disappointing expectations the public naturally has. The arbitrariness of the outcomes, in relation to the process that generated them, invites clever argument and gaming as well; and the judiciary, with fewer colors to its palette, will inevitably produce surprising outcomes. ${ }^{234}$

The textualist response is that Congress and the agencies, understanding that the judiciary will limit itself to the statutory text, will respond with clearer expressions. Here again we touch a large literature of debate about the perfectibility of expression that is not necessary to repeat. Regarding the agency contribution, however, it may be appropriate to add these thoughts: First, the problem with statutes today is rarely that they are too terse, but the opposite. Many ascribe that to Congress's interaction with the agencies-its wish to see them well-instructed. Courts are not necessarily performing a public service, or generating more readily predictable outcomes, in encouraging Congress to be more verbose. ${ }^{235}$ Second, inviting the agencies to rely on text alone, disregarding political background and understanding, will if successful destabilize agency administration, which is even more subject to political pressures than are the courts. ${ }^{236}$ Third, it is hard to imagine that such an invitation would be consistently acted upon, given the different settings in which agencies and courts work. Finally, and most important in my judgment, the turn to text, even if the agencies make it, still delegitimizes their role and defeats the possibility of justified reliance on their actions. Absent some principles like those of American Trucking, principles wholly missing in City of Cbicago, the agencies' efforts with the text will be no more than an interesting prelude to the judiciary's reading. They will not contribute to the generation of law; the incentives these principles provide against litigation will drop away. And, in this way, the

\footnotetext{
${ }^{234}$ See Merrill (cited in note 41), 72 Wash U L Q at 372.

${ }^{235}$ See Lieber, quoted in note 33.

${ }^{236}$ Peter L. Strauss, When the Judge Is Not the Primary Official with Responsibility to Read: Agency Interpretation and the Problem of Legislative History, 66 Chi Kent L Rev 321 (1990).
} 
courts' work in the middle part of this century, accommodating themselves to agencies' as they had to statutes' intrusions on their work of law administration, will have been discarded.

The central point here is that the textualist, static approach denies the conversational, evolutionary character of the congressionalagency relationship. In relation to private conduct, judges have no difficulty in accepting such realities. Thus, Justice Scalia uttered the epigram of this essay in concurring with an otherwise unanimous opinion (the opinion, otherwise uninteresting here, turned on a Treasury Department regulation requiring the disclaimer of a trust interest within a "reasonable time" of the interest's creation, to escape gift tax):

The justification for the "reasonable time" limitation must, as always, be a textual one. It consists, in my view, of the fact that the failure to make a reasonably prompt disclaimer of a known bequest is an implicit acceptance. Qui tacet, consentire videtur. ${ }^{237}$

Acceptance of the same "textual" justification to govern the closely watched behavior of federal agencies (and courts) administering federal statutes would have led to different results here and in many other cases.

We can perhaps imagine why Justice Scalia might argue that Congress's behavior cannot be treated in the same fashion as the taxpayer who failed to disclaim. Under the Constitution, Congress legislates only by the action of both houses with presentment to the President. Its silence cannot create legislation. This may be conceded. It only carries the day as an argument, however, if one also holds that the courts and the agencies are not also authorized to make law - to fill in gaps as well as to interpret-in partnership with Congress. That is the move, the radical segregation of the legislative from the judicial and administrative enterprise, the denial of joint effort, that is the engine of these opinions. Otherwise, we do not have to say that Congress by silence has amended the statute, as self-evidently it has not; rather, we say that the congressional silence (along with other factors) arms the interpretation that, like their other work, courts are adopting in their own right, attempting as best they can to pursue "the ideal of a unified system

${ }^{237}$ United States $v$ Irvine, $114 \mathrm{~S}$ Ct 1473, 1483 (1994). 
of judge-made and statute law woven into a seamless whole by the processes of adjudication." ${ }^{238}$ In the context of their common law responsibilities, courts fill in gaps; in exercising delegated power, agencies do so as well. The proposition that they are disabled from doing so in dealing with legislation, far from obvious, is not just a reaction to recent excesses; it defeats the last century of American law.

Wouldn't one want at least to see the full course of RCRA's administration on this issue and how EPA understood both the initial statute and its 1984 amendment by $\S 3001(i)$-and see them reflected, as well, elsewhere than in the single case before the Court? The result the City of Cbicago majority reached may be better policy, in the abstract, than any observer could reasonably have thought Congress accomplished in 1984 (though one would want to know something about just how terrible the hazardous waste problem is, what municipal waste ashes probably contribute, and what expenses the majority's position will impose). But nothing we know suggests that it was the policy Congress sought to implement; and every political instinct tells us that, if that policy bad been appreciated as the amendment's aim, it would have been fully discussed. Indeed, to assume that the drafter of the amendment's text knew it meant what the Court majority insisted it could only mean, is to tell this story as an abuse of legislative process, as one in which clever staff and lobbyists (in this case, for the EDF) put one over on their bosses. The bureaucratic character of today's Congress reflects itself in gargantuan texts no member has read, as well as in the materials of legislative history ${ }^{239}$ - and will, the more so, with judicial encouragements to prolixity. The result here is strictly the Court's contribution; "the text requires it," a facade.

\section{CENTRAL BANK OF DENVER V FIRST INTERSTATE BANK OF DENVER}

Greenwich Collieries, ${ }^{240} M C I,{ }^{241}$ and City of Cbicago all find reflections in Central Bank of Denver $v$ First Interstate Bank of Denver. ${ }^{242}$

\footnotetext{
${ }^{238}$ Stone, work cited in $\mathbf{n} 8$.

${ }^{239}$ Compare Blanchard v Bergeron, 489 US 87, 98-99 (1989) (Scalia concurring).

${ }^{240}$ Discussed in text following $\mathrm{p} 486$.

${ }^{241}$ Discussed in text following $\mathrm{p} 493$.

242114 S Ct 1439 (1994).
} 
Here the issue concerned the meaning of $\S 10(b)$ of the Securities Exchange Act of $1934 .{ }^{243}$ Section 10(b) makes it "unlawful for any person, directly or indirectly, . . . to use or employ [in security trading] . . . any manipulative or deceptive device or contrivance in contravention of such rules and regulations as the [SEC] may prescribe." Central Bank, in its role as trustee on indentures issued by a Colorado public authority to finance real property under development, arguably had aided and abetted the Authority's and the developer's violation of $\S 10(\mathrm{~b})$. First Interstate, harmed in the financial fallout of the violations, sued Central Bank along with those directly responsible for the fraud. It invoked the private remedy given by SEC Rule $10 \mathrm{~b}-5^{244}$ on the basis of this conduct "aiding and abetting" the underlying fraud. "Hundreds of judicial and administrative proceedings in every circuit in the federal system" 245 had previously found that $\S 10(\mathrm{~b})$ 's prohibition on the "use" of a device reached the secondary aiding and abetting of violations, both in connection with SEC enforcement actions and in Rule 10b-5 suits. In the lower courts, narrower questions were disputed: whether this secondary liability extended to indenture trustees who had violated none of their obligations under state law; whether the aider and abettor must have been reckless, not merely negligent. In Justice Stevens's characterization, Central Bank, the defendant in the action and the petitioner before the Court, "assumed the existence of a right of action against aiders and abettors, and sought review only of . . . [these] subsidiary questions . . . . But instead of simply addressing the questions presented by the parties, on which the law really was unsettled, the Court sua sponte directed the parties to address [the existence or not of the right of action,] a question on which even the petitioner thought the law was settled, and reaches out to overturn a most considerable body of precedent." 246

Justice Kennedy wrote for the Chief Justice and Justices Scalia, O'Connor, and Thomas that the text of $\S 10(\mathrm{~b})$, as enacted in 1934 and not since amended, could not support private (Rule 10b-5) liability for "aiding and abetting." After noting that the question

\footnotetext{
${ }^{243} 15$ USC \& 78j.

${ }^{244} 17$ CFR § 240.10b-5 (1993).

${ }^{245} 114 \mathrm{~S} \mathrm{Ct}$ at 1456 (Stevens dissenting) (emphasis in original).

${ }^{246}$ Id at 1457 (emphasis in original).
} 
had been open since the Court had signaled its doubts in the mid1970 's, he turned to the meaning of $\S 10$ (b), on which "the text of the statute" controls. For him, it was "uncontroversial" that the text "does not itself reach those who aid and abet a $\S 10(\mathrm{~b})$ violation. .. . [T] hat conclusion resolves the case. . . . We cannot amend the statute to create liability for acts that are not themselves manipulative or deceptive within the meaning of the statute." 247 At greater length, he also explained why a court should reach the same result even if the statute did not resolve the case: Congress in 1934 had shown no inclination to attach "aiding and abetting" liability in those cases in which it expressly created private causes of action under the securities law. Neither the general criminal provision on aiding and abetting, ${ }^{248}$ nor any other source, show a general congressional purpose to establish aiding and abetting as a basis for civil liability associated with federal statutes. The 1934 Congress could not be thought to have accepted such liability as an anticipatable offshoot of general tort principles. And, finally, no post-1934 amendments to securities legislation spoke directly to the aiding and abetting question. Justice Kennedy noted that Congress had failed in the late 1950's to enact proposed legislation that would have made such liability explicit, and then, after the SEC and the courts developed that liability in the course of decision, failed to correct it; he thought neither silence persuasive. Finally, he concluded, policy considerations advanced by the SEC "cannot override our interpretation of the text and structure of the Act . . . . [I]t is far from clear that Congress in 1934 would have decided that the statutory purposes would be furthered by the imposition of private aider and abettor liability."249

Thus, the static character of statutory law, which courts (and agencies) do not influence, is once again a dominant theme of the majority. The questions are what was in the statute in 1934, what attitude or understanding the Congress of 1934 might have had to

\footnotetext{
${ }^{247}$ Id at 1448.

24818 USC $\$ 2$

$249114 \mathrm{~S} \mathrm{Ct}$ at 1454 (emphasis added). The majority appears not to have been indifferent to policy considerations; Justice Kennedy's opinion makes clear that he was aware of the argument that American liability principles, as they had developed, might be making it harder for "newer and smaller companies . . . to obtain advice from professionals." Id at 1454. But the Court's rhetorical position was not that a change in course might now be warranted; rather, it was that the SEC and private plaintiffs had, from the beginning, been relying upon absent authority.
} 
private causes of action or secondary liability, and the like. One can argue, as Justice Stevens does in his dissent (joined by Justices Blackmun, Souter, and Ginsburg), whether the majority has correctly assessed the likely stance of Congress in 1934; Justice Kennedy makes it far more conservative and chary of administrative innovation than most historians would likely ascribe to the early New Deal Congress. But that is secondary to the static quality of the analysis generally-its hostility both to the idea of meaning evolving over time, and to ascribing significance to agency administration. The SEC's views on policy are equated with those a private party might advance; they are calls on the Court for discretionary action, rather than a reflection of assigned responsibility. Indeed, while the opinion states that it only concerns private liability under Rule 10b-5-a subject to which the Court has been increasingly hostile in recent years-its reasoning limns the permissible meaning of $\S 10(\mathrm{~b})$, which the SEC enforces directly. The plain implication, as the dissent points out, is that the SEC can no longer bring enforcement actions based on aiding and abetting. ${ }^{250}$ Given this reasoning, it is remarkable that the Court fails directly to confront either the SEC's authority or the implications to be drawn from the SEC's continuous pursuit of such actions under congressional oversight. $^{251}$

For the dissent, in contrast, the central idea is the importance of respecting the shape $\S 10(\mathrm{~b})$ and Rule $10(\mathrm{~b})(5)$ has assumed over time. "While we have reserved decision on the legitimacy of the theory in two cases that did not present it, all 11 Courts of Appeals to have considered the question have recognized a private cause of action against aiders and abettors. . . ." J52 Justice Stevens might have added that the reservations were expressed in 1976 and 1977; the following 18 years of administration of the rule, without con-

${ }^{250}$ Compare the following from Skidmore, cited in note 231, describing reasons why courts should conform their interpretations in private actions to those an agency was seeking publicly to enforce: "Good administration of the Act and good judicial administration alike require that the standards of public enforcement and those for determining private right shall be at variance only when justified by very good reasons." 323 US at 140 . Skidmore, of course, was reasoning in the opposite direction, from the agency's public authority rather than to conclusions what it must be.

${ }^{251}$ As previously noted, the opinion does consider the implications of proposals to Congress, and of failures to amend $\S 10(\mathrm{~b})$ when other provisions were changed. The point here is the different one developed in the text following p 504-that during these years a body Congress had appointed to act as its agent had consistently been behaving in a certain way, and Congress had shown no disposition to correct it.

${ }^{252} 114 \mathrm{~S} \mathrm{Ct}$ at 1456. 
gressional reaction to the signal thus given, suggest solidified consensus, not continuing doubt, about the underlying position. "A policy of respect for consistent judicial and administrative interpretations leaves it to elected representatives to assess settled law and to evaluate the merits and demerits of changing it." ${ }^{253}$ Here, Justice Stevens appended a footnote noting prior congressional correction of the Supreme Court's recent overruling of settled securities lawstrongly suggesting that here, as in Landsgraf and Rivers, ${ }^{254}$ the Court has been battling with Congress rather than implementing its decisions. "[W]e should . . . be reluctant to lop off rights of action that have been recognized for decades, even if the judicial methodology that gave them birth is now out of favor . . . particularly . . . because the judicially recognized right in question accords with the longstanding construction of the agency Congress has assigned to enforce the securities laws." 255 From a perspective treating Congress as a constant monitor of evolving agency and judicial interpretations, subsequent congressional actions spoke more loudly of acquiescence to Justice Stevens than to Justice Kennedy. Justice Stevens's principal point was that the statute's meaning in 1934 was not limiting, if one could today find in its terms support for the approach that had been taken. That support is provided by the statute's reference to persons who "directly or indirectly" use manipulative devices, and by the usual openness of common law courts to building liability on such foundations as the criminal law's general extension of liability to aiders and abettors. As he had in his dissent from Patterson years earlier, ${ }^{256}$ Justice Stevens ended his dissent by invoking Benjamin Cardozo's The Nature of the Judicial Process. The majority's refusal "to build upon a 'secure foundation . . . laid by others," "257 is in the service of instability and, one might add, politicization in American law.

\section{E. NLRB V HEALTH CARE \& RETIREMENT CORP. OF AMERICA}

Readers who have reached this point will not doubt my unhappiness with the Term's developments. They may have questions

\footnotetext{
${ }^{253}$ Id at 1458.

${ }^{254}$ Discussed in text following $\mathrm{p} 454$.

$255114 \mathrm{~S} \mathrm{Ct}$ at 1460.

${ }^{256}$ Text at $\mathrm{n} 99$ above.

$257114 \mathrm{~S} \mathrm{Ct}$ at 1460.
} 
about the fairness of my summarizing of what are, of necessity at the Court's level, complex issues and arguments. Surely my impatience has inflected my tone. Surely it has, although my effort has been to present the Justices' arguments in their own termsbelieving this tree should fall of its own weight, and rhetorical distortion would be a disservice to my effort. In any event, the majority opinion in this workaday NLRB case may help to quell the suspicion that $I$ am the one supplying the tone toward legislative effort that sometimes marks these pages.

As part of the Taft-Hartley Act of 1947, Congress adopted two definitions of who might and might not be a statutory "employee" eligible to organize that appear to be in considerable tension with one another. Section 2(3) expressly excludes from the category "employee" any individual employed as a "supervisor," 258 and § 2(11) defines a supervisor as a person having "authority, in the interest of the employer," to perform a variety of tasks in relation to other employees, including the authority to "assign," "responsibly to direct," or "effectively to recommend" such action, if it "requires the use of independent judgment." 259 Section 2(12), on the other hand, expressly includes as statutory "employees" "professional employees," persons whose work involves "the consistent exercise of discretion and judgment in its performance." ${ }^{260}$ Professionals' "exercise of discretion and judgment" very often includes giving assignments to other employees and directing their performance to some extent; the reader imagining the work of a lawyer in a public defender's office, for example, will easily see how this must be so. One has, then, an inevitable issue of characterization, whether professionals are excluded supervisors or included employees, on particular facts.

In NLRB $v$ Health Care \& Retirement Corp. of America, ${ }^{261}$ the Court was reviewing the Labor Board's assessment of this issue for staff nurses working at nursing homes. On the one hand, the nurses are clearly professionals; on the other, management staff was on hand only during normal weekday business hours, and during the rest of the week - that is, the substantial majority of a nursing home's

\footnotetext{
${ }^{258} 29$ USC § 152(3).

${ }^{259} 29$ USC $\S 152(11)$.

26029 USC § 152(12).

${ }^{261} 114$ S Ct 1778 (1994).
} 
operating hours-the nurses on duty had immediate charge of the larger number of nurses aides. The aides were the ones more likely to deal directly with patients on routine matters; they required assignment and oversight; and their conduct might have to be reported for consideration of praise or discipline. This of course was not a new issue in 1994. The Board's consistent position has been that these nurses are "professional employees" and are not "supervisors." To the Court, it argued that their direction of the aides was professional rather than managerial in character, and hence was not "in the interest of the employer" as it understood § 2(11).

Justice Kennedy wrote for the five most consistent textualists and Justice Ginsburg for the four most frequent contextualists, finding the nurses to be excluded supervisors and included professionals, respectively. While Justice Kennedy drew support from a single Supreme Court precedent excluding Labor Act coverage of a similarly conflicted situation, ${ }^{262}$ his principal arguments drew on his understanding of Congress's action in 1947 and were indifferent to subsequent events. He took the phrase, "in the interest of the employer," to have the broad meaning that had been given it in a then-recent Supreme Court opinion whose result the Taft-Hartley Act had intended to reverse. ${ }^{263}$ That the Board, the national body responsible in the first instance for giving shape to national labor policy, had consistently understood the phrase in a different wayeven as applied to nursing homes-is dismissed; in other settings involving the "professional"-"supervisor" tension, the Board had relied on other rationales than its interpretation of "in the interest of the employer," and it was the use of that particular argument, rather than uniformity of outcome, that Justice Kennedy found significant. "[I]n almost all of those cases (unlike in cases involving nurses) the Board's decisions did not result from manipulation of the statutory phrase 'in the interest of the employer,' but instead

\footnotetext{
${ }^{262}$ NLRB v Yeshiva University, 444 US 672 (1980). Here, the issue was whether faculty members were "managerial employees," and the Board had argued that they acted in their own, rather than their employer's, interest.

${ }^{263}$ Packard Motor Car Co. v NLRB, 330 US 485 (1947). In contrast to Justice Ginsburg's careful survey of the legislative history, Justice Kennedy said of the legislative history only that "there is no indication that Congress intended any different meaning when it included the phrase in the statutory definition of supervisor . . . in 1947." $114 \mathrm{~S} \mathrm{Ct}$ at 1782. While Congress repudiated the result in Packard, "we of course have rejected the argument that a statute altering the result reached by a judicial decision necessarily changes the meaning of the language interpreted in that decision." Id at 1783.
} 
from a finding that the employee in question had not met the other requirements for supervisory status." ${ }^{264}$ When the Act was amended in some but not these respects in 1974, the Board's interpretations were before Congress; the approving mention of these interpretations in a Committee report is not binding on the courts, "for the Constitution is quite explicit about the procedure that Congress must follow in legislating." 265 "If Congress wishes to enact the policies of the Board, it can do so without indirection."266 These impatient words are Justice Kennedy's; assuming as they do that Congress should have known the Board was in error, they reflect a strikingly antagonistic and formal stance to the interrelation of legislative, agency, and judicial effort, and one that essentially denies the possibility of law's growth over time, or of Congress's assignment to others of responsibility in that regard.

Justice Ginsburg gave closer attention to the inherent tension between the two statutory definitions involved and the Board's primary responsibility for the Act. Within that context, she found the legislative history supported the interpretation the NLRB had given language over time, and noted the consistency of this interpretation with other well-established aspects of the Board's work. "The Board's endeavor to reconcile the inclusion of professionals with the exclusion of supervisors, in my view, is not just 'rational and consistent with the Act'; it is required by the Act."267

\section{F. UNITED STATES DEPARTMENT OF DEFENSE V FEDERAL LABOR RELATIONS AUTHORITY}

The dispute in United States Department of Defense $v F L R A^{268}$ required the Court to interrelate three somewhat disparate statutes-

\footnotetext{
${ }^{264}$ Id at 1785 .

${ }^{265} 114 \mathrm{~S} \mathrm{Ct}$ at 1784, quoting American Hospital Association v NLRB, 499 US 606, 616 (1991). In this respect, this opinion reiterates the misleading "single mention" reasoning of Shannon, City of Cbicago, and Central Bank of Denver, discussed above at pp 471, 499, and 509. It does not follow from their undoubted insufficiencies as legislative acts that these events are irrelevancies for a court interpreting the phrase. That would be so only if the expert judgment of the agency appointed by Congress to administer the laws in the first instance, the course of interpretation over time, and its apparent acceptance by Congress had no appropriate bearing on judicial judgment on the matter.

$266114 \mathrm{~S} \mathrm{Ct}$ at 1785.

${ }^{267} 114 \mathrm{~S}$ Ct at 1793 (emphasis in original), quoting NLRB v Curtin Matheson Scientific Inc., 494 US 775,796 (1990).

${ }^{268} 114 \mathrm{~S} \mathrm{Ct} 1006$.
} 
the Federal Labor Relations Act ("the Act"), ${ }^{269}$ the Privacy Act, ${ }^{270}$ and the Freedom of Information Act ("FOIA"). ${ }^{271}$ Its performance reflects, again, a disinclination to take an actively integrative role. The Act, in general, seeks to bolster the position of public unions, giving them rights comparable to those enjoyed by employee representatives in the private sector; and $\S 7114(\mathrm{~b})(4)$, in particular, requires agencies to furnish their public employee unions with data necessary for collective bargaining purposes, "to the extent not prohibited by law." Employee unions sought the names and home addresses of employees in the bargaining units they represented-a request a private employer would be required to honor under the National Labor Relations Act. ${ }^{272}$ Under the Privacy Act, release of such personal information is prohibited unless disclosure would be "required" under FOIA. ${ }^{273}$ And FOIA, in turn, requires agencies to comply with "any person['s]" demand for information in government possession, unless one of its exemptions applies-in this instance, its sixth exemption, for "personnel and medical files and similar files the disclosure of which would constitute a clearly unwarranted invasion of personal privacy." ${ }^{274}$ Could one look to the Act and the focused judgment of the Federal Labor Relations Authority ("FLRA") that such disclosure was necessary for collective bargaining, in assessing the existence or not of "warrant" for invading an employee's personal privacy by disclosing her home address? Or may that invasion be "warranted" only by the sort of general considerations that might attend "any person['s]" request for this information, as assessed by a reviewing court?

Justice Thomas wrote the majority opinion finding that the information could not be disclosed. As Justice Ginsburg pointed out in a bittersweet concurrence, all courts of appeals to address this issue before 1989 had easily interpreted these three acts, in conjunction, to permit enforcement of the FLRA's judgment. Congress's labor policy choice to promote collective bargaining for federal civil ser-

\footnotetext{
2695 USC $\$ \S 7101-35$.

2705 USC $\S 552 \mathrm{a}$.

2715 USC $\$ 552$.

${ }^{272}$ For example, NLRB $v$ Associated Gen. Contractors of Cal., Inc., 633 F2d 766 (9th Cir 1980), cert den, 452 US 915 (1981), cited in $114 \mathrm{~S} \mathrm{Ct}$ at $1017 \mathrm{n} 9$.

${ }^{273} 5$ USC \& $552 \mathrm{a}(\mathrm{b})(2)$.

2745 USC $§ 552(\mathrm{~b})(6)$.
} 
vants provided a solid basis for concluding that the disclosure of home addresses to a bargaining representative was not "a clearly unwarranted invasion of personal privacy"; the disclosure placed federal unions and the federal employer in an equivalent position to unions and employers under the NLRA. "It is surely doubtful that, in the very statute bolstering federal-sector unions, Congress aimed to deny those unions information their private-sector counterparts routinely receive." 275

Congress did not relevantly amend any of the three acts involved subsequent to these interperetations. But in 1989 the Court decided, in the context of the FOIA's similarly worded exemption for investigative files ${ }^{276}$ that the balancing suggested by reference to an "unwarranted invasion of personal privacy" could not consider the identity of a particular requester and the legitimacy of its needs, since the Act confers the right to information on "any person." Rather, one must justify disclosure in terms of FOIA's "core purpose" of "contributing significantly to public understanding of the operations or activities of the government."277 Since that decision, all but one of the courts of appeal considering the matterincluding a panel of the D.C. Circuit on which Justice Ginsburg had sat ${ }^{278}$-found that this restructured inquiry compelled the conclusion that the addresses could not be released. The general public would learn little if anything about the operation of government from their disclosure, and so in the only terms that now counted there was no warrant at all to counterbalance public employees' privacy interest in having their addresses secure from disclosure to the public.

The case provided the majority a straightforward occasion for applying its earlier precedent. FOIA gives the right to information to "any person," and gives that right in order to enhance knowledge

\footnotetext{
${ }^{275} 114 \mathrm{~S} \mathrm{Ct}$ at 1018.

2765 USC $\$ 552(\mathrm{~b})(7)(\mathrm{C})$ exempts law enforcement records to the extent that their production "could reasonably be expected to constitute an unwarranted invasion of personal privacy."

${ }^{277}$ Department of Justice v Reporters' Committee for Freedom of Press, 489 US 749, 775 (1989). The public's interest in knowing the contents of criminal "rap sheets" on individuals could be expected to do little to expose the operations of government, but could constitute a significant invasion of the privacy of individuals who might never have been tried for the crimes alleged on them.
}

${ }^{278}$ FLRA v Department of Treasury, 884 F2d 1446 (DC Cir 1989), cert den, 493 US 1055 (1990). 
about government. That policies external to FOIA make a strong case for making this information available is irrelevant to a case that arises within its four corners. In one sense, the Court is assuming responsibility for the statute's shape; as Justice Ginsburg remarked, the " "core purpose' limitation is not found in FOIA's language," but was supplied by the Court in the particular context of disclosing information about criminal investigations; here, it is extending that reasoning. ${ }^{279}$ Yet, "in the matter at hand, . . . it is Congress that has declared the importance of the request's purpose, and Congress that has selected a single entity-the employees' exclusive bargaining representative-as entitled to assert that purpose." 280 In its insistence that "we do no more than give effect to the clear words of the provisions we construe," 281 in declining to accept what it describes as "respondents' ambitious invitation to rewrite the statutes before us," 282 the majority denies its partnership with Congress. "Speculation about the ultimate goals of the Labor Statute is inappropriate" 283 where the words are clear; if the Court's interpretation creates a difference between private and public labor law that is contrary to the responsible agency's view, inexplicable as labor policy and irreconcilable with the general purposes of the Act, "Congress may correct the disparity." 284 It is not for the Court to seek the integration of statutory commands that Justice Ginsburg shows to be both available, and a fairer rendering of overall public policy attributable to Congress; it is not for the Court to pursue "the ideal of a unified system of judge-made and statute law woven into a seamless whole by the processes of adjudication." 285

\section{G. THREE COUNTER-EXAMPLES?}

1. Jobn Hancock Mutual Life Insurance Co. v Harris Trust and Savings Bank. Jobn Hancock Mutual Life Insurance Co. v Harris Trust and

${ }^{285}$ Stone, work cited in note 8. Justice Ginsburg's concurrence rests on the strength, as she reports it, of her colleagues' views and of statutory stare decisis. 114 S Ct at 1019 (Ginsburg concurring).
} 
Savings Bank ${ }^{286}$ was Justice Ginsburg's first opinion of the Term and the first opinion to consider issues of statutory interpretation in detail. Justice Ginsburg's cases, even when (as often) fairly closely divided, tended not to produce the rhetoric of division which concerns this essay, and that was also the case in Hancock. If one can find the Term's patterns here, they are in subdued form.

The Court decided, 6-3, that John Hancock's administration of certain annuity contracts subjected it to the fiduciary standards of the Employee Retirement Income Security Act of 1974, ERISA. ERISA is a complex statute, and the problem of interpretation facing the Court defies easy description. In general, ERISA makes persons responsible for managing the assets of retirement plans into fiduciaries of plan beneficiaries, with corresponding duties and limitations respecting their investment decisions. However, 29 USC $\S 1101(b)(2)(B)$ creates an exception for the assets of insurance companies who issue retirement policies, "to the extent that [a] policy or contract provides for benefits the amount of which is guaranteed by the insurer." Insurance companies are predominantly regulated by state law, which tends not to regard them as fiduciaries for their policy-holders; exemption from fiduciary status is thus of some importance to them. The consequence of characterizing a given plan as a guaranteed benefit plan is that the manager will be considerably freer to commingle investment funds for the plan with its general funds, to deal in securities of the employer purchasing the plan, and so on. Should Hancock's plan with the Sperry Rand Corporation, of which Harris Trust and Savings was trustee, be so characterized? Following a common insurance industry practice in administering retirement plan portfolios, the plan guaranteed the benefits a Sperry employee would receive ultimately; during the period before any particular employee retired, however, the funds contributed on her account were treated as part of the insurer's general investment pool. To the extent Hancock was successful in its investments, it built up surpluses, beyond the level its guarantees required it to pay. These surpluses and the possibility that retirees would share in them as a supplement to their defined benefits produced the question to what extent this was a "guaranteed benefit" plan. Disputes over how and on what valuations Hancock would share them with the retirement plan

${ }^{286} 114$ S Ct 517. 
in question produced the occasion for deciding whether it was a "fiduciary," and the Court held that it was. It did so in the face of contrary, but somewhat hesitant, advice from the Department of Labor and, according to the dissent, nearly 20 years of conduct based on the opposite understanding in the insurance industry as a whole.

It may be appropriate for our purposes to focus on the tools of interpretation invoked by the two opinions. In its breadth of consideration of statutory patterns, congressional process, and integration with the decision of other like questions, the majority opinion generally reflects a contextual style of analysis. For Justice Ginsburg and the majority, the important considerations were ERISA's general pattern of inclusion, and the limited ("to the extent that") way in which the statute stated the "guaranteed benefit" exclusion from the general principle of fiduciary obligation. The latter qualification held particular importance; other exclusions were stated in a much broader fashion. Similar exemptions in other, like statutes had been interpreted narrowly. In adopting the exclusion, moreover, the Senate had rejected a broader formulation, that would clearly have entitled Hancock to prevail. And prior cases, arising in analogous circumstances, tended also to suggest that " $[t]$ o the extent that [Hancock] engages in the discretionary management of assets attributable to that phase of the contract which provides no guarantee of benefits payments or fixed rates of return, . . . [it] should be subject to fiduciary responsibility."287

The majority was unresponsive, however, to claims of administrative interpretation and of insurance industry practice during the first two decades of ERISA's administration. In 1975, shortly after ERISA had been enacted, the Department of Labor had taken the contrary position in an interpretive bulletin addressing another but coordinate question, whether in like circumstances an insurance company could engage in transactions involving the company whose plan it was administering. Insurance companies like Hancock administered plans like Sperry's as if they were not fiduciaries, to the extent of $\$ 332$ billion, ${ }^{288}$ without prompting a regulatory response. The Departmental bulletin, however, did not focus on the question of fiduciary status or the "guaranteed benefit" issue,

\footnotetext{
${ }^{287}$ Id at 528, quoting the opinion below, $970 \mathrm{~F} 2 \mathrm{~d} 1138,1144$ (2d Cir 1992).

${ }^{288}$ Id at 531 (Thomas dissenting).
} 
and the majority was unpersuaded that treatment of its questions was implicit there. It also noted that in 1992 the Department of Labor had been unwilling to provide requested assistance on the precise point to the Second Circuit, pleading the complexity of the issues and the press of other business. The majority concluded that the text of ERISA would not support the interpretation the Department urged. The majority's response to the practical concerns expressed by the Department of Labor and the industry was that "we cannot give them dispositive weight" and that "administrative relief" of an unspecified character might be available.

One finds the opposite pattern in Justice Thomas's opinion for himself, Justice O'Connor, and Justice Kennedy. He begins by parsing the phrases of $\S 1101(\mathrm{~b})(2)(\mathrm{B})$ in turn, and in isolation"provides for," "the amount of which is guaranteed," and then, finally and quite briefly, "to the extent that." The history of consideration in the Senate, the unusual character of this exclusion compared with others in ERISA, overall ERISA policy, and learning from other statutes are beside the point.

Unlike the Court, I see no need to base an understanding of [the guaranteed benefit exception] on principles derived from the interpretation of dissimilar provisions in the Securities Act of 1933 or from a sense of the policy of ERISA as a whole. The meaning of the provision can be determined readily by examining its component terms.

More surprising, Justice Thomas calls attention as well to considerations of practical impact and community expectations about what statutes mean, factors generally absent from his analyses during the Term. The majority wrote $a s$ if its conclusion would affect only a part of one particular insurance arrangement. Justice Thomas argues that the structure of Hancock's business assures that, in fact, the decision will have a sweeping impact on how it does business; it deals with many plans as it does with Sperry's, mingling all their funds in its general accounts up to the point at which any particular employee retires and begins to draw benefits. To apply principles of fiduciary responsibility at this stage is, as he characterizes it, to "radically alter[] the law applicable to insurance companies." 289 As a formal matter, as Justice Thomas would usu-

${ }^{289}$ Id at 535. 
ally describe "law," this statement is untrue: The language of ERISA has not been changed since its enactment and had not been definitively interpreted by the Supreme Court in the interim. ${ }^{290}$ The 1975 interpretive bulletin concerned another, although related, subject. And, an interpretive bulletin in any event does not establish binding law. If it established a shared understanding throughout the insurance industry, "[i]n reliance on [which] settled understanding" the insurance companies had been conducting their business, ${ }^{291}$ without congressional response, that is in the framework of this essay a sound argument for interpreting ERISA as Hancock urged. It is, however, the kind of argument that, in other cases, the dissenters usually rejected.

2. PUD No. 1 of Jefferson County $v$ Washington Department of Ecology. Under the Clean Water Act, the states and the federal government share responsibility for "restor[ing] and maintain[ing] the chemical, physical and biological integrity of the Nation's waters, ${ }^{292}$ and states are encouraged to develop comprehensive standards that may be more stringent than federal standards. The states may include enhancing water quality, preventing degradation, and assuring "water quality which provides for the protection and propagation of fish, shellfish and wildlife" among their goals. ${ }^{293}$ In general, administration of the Act and approval of state standards or private initiatives that may come within its terms are the business of the Environmental Protection Agency (EPA). Section 401 of the Act ${ }^{294}$ can bring other federal regulators into the picture, however; applicants for any federal license or permit "which may result in any discharge into the navigable waters" must secure from the state a certificate "that any such discharge will comply with [the Act]." Section 401 also provides that "any certification provided under this section shall set forth any effluent limitations and other limitations [under the Act or appropriate requirements of State law,]" which "shall become a condition on any Federal license or permit." An application to the Federal Energy Regulatory Commission

\footnotetext{
${ }^{290}$ Compare the civil rights retroactivity cases, discussed in the text at $\mathrm{p} 454$, and the treatment of the burden of proof issue in Director, Office of Workers' Compensation Programs $v$ Greenwich Collieries, discussed at $\mathrm{p} 486$.

291114 S Ct 535.

29233 USC $§ 1251(a)$.

29333 USC \& 1251(a)(2).

29433 USC $\$ 1341$.
} 
(FERC) for a license to operate a hydroelectric facility is one such application. A Washington state standard sought to protect a stream's fish life by requiring a certain amount of water to be left in the stream after diversion for other uses, such as hydroelectric power generation. Does that standard qualify as an "other limitation[]"; or is it outside the statute since it concerns water left in the river rather than removed to generate power and then returned ("discharged")?

In PUD No. 1 of Jefferson County $v$ Washington Department of Ecology, ${ }^{295}$ Justice O'Connor, writing for seven Justices, accepted the state standard as a qualifying condition, after considering the EPA's view as embodied in its regulations and practices, and other contextual factors. Justices Thomas (writing) and Scalia found a more restrictive meaning in the statute's textual reference to "any discharge," and were unpersuaded by the course of administration the statute was said to have received at EPA. The differences were not stark. While in general the dissent appeared to be the more concerned with the limits text imposed, in one respect it gave more reflective attention than the majority to the integrative responsibilities of courts.

Justice Thomas would have left the issue of stream flow protection to be decided federally by FERC, a view that drew force from FERC's role. In licensing a proposed hydroelectric facility, FERC is required to consider "the protection, mitigation of damage to, and enhancement of fish and wildlife." 296 Section 10(a) of the Federal Power $\mathrm{Act}^{297}$ empowers it to impose conditions, including minimum stream flow, to that end. Earlier judicial interpretations of this fish-protection authority had found that it preempted state requirements, even requirements for bigher flows. ${ }^{298}$ In effect, FERC must think about protecting fish, but has some discretion to prefer electricity. In PUD, the majority's interpretation of the Clean Water Act gives states a way to make their stream flow preferences necessary conditions of any later federal licenses, including hydroelectric licenses. The interpretation thus pretermits FERC's power to compromise between the nation's needs for electricity and its interest in fish protection.

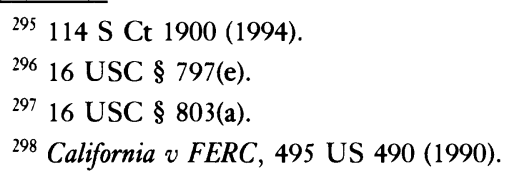


The majority found no conflict between FERC and the state, since FERC had not yet acted on a license application; in arguing amicus for the government, the Solicitor General had represented that FERC had no objection to the stream flow condition. ${ }^{299}$ For the dissent, this reasoning failed to make a reasonable whole of the federal statutes. If the issue was merely avoiding after-the-fact state frustration of prior federal determinations, the majority approach might be acceptable; if, on the other hand, Congress has given FERC the federal role of reconciling national interests in electricity supply and stream flow protection for fish, it is not responsive to observe that a policy attributable to EPA takes effect prior to FERC's opportunity to act. A holistic, integrative account of the statutes would nonetheless have to recognize FERC's primacy; such accounts are perhaps especially needed in settings of great regulatory complexity, in which Congress may often have created, out of inadvertence, arguably redundant responsibilities. Here too, then (as Justice Stevens recognized in a wry, one-paragraph concurrence), Justice Thomas appears to have departed from his more frequently static view of legislation.

3. Thomas Jefferson University $v$ Shalala. Thomas Jefferson University $v$ Shalala ${ }^{300}$ divided the Court 5-4, along unusual lines, about the meaning of Department of Health and Human Services regulations implementing Medicare. Justice Kennedy's majority opinion attracted Justices Blackmun and Souter in addition to the Chief Justice and Justice Scalia; Justice Thomas's dissent was joined by Justices Stevens, O'Connor, and Ginsburg. Here the issue concerned, not the potential of conflict between two federal agencies, but the clarity with which one had provided in its regulations for matters unquestionably under its control. One problem Medicare authorities face in reimbursing teaching hospitals for their patients is that the hospital may be seeking reimbursement as a medical expense for an item that ought to be viewed as an educational expense. The problem is underscored by Congress's increasing concern to control Medicare costs generally. It surfaced here when Jefferson Medical School reexamined the accounting practices it had been following and decided it could properly claim reimbursement as medical items for some expenses it previously had been

$299114 \mathrm{~S} \mathrm{Ct}$ at 1914.

300114 S Ct 2381 (1994). 
financing on the educational side-perhaps thus recapturing funds it was losing to more stringent cost controls elsewhere. Jefferson at first lost, then won, then finally lost these claims within the Department, when the Secretary interpreted a regulation quoted in the margin as forbidding the reimbursement. ${ }^{301}$ Justice Kennedy, for the majority, resolved the dispute in the Secretary's favor largely in reliance on the conventional proposition that her reasonable interpretation of her own regulation was entitled to control. ${ }^{302}$

Like his opinion in Jobn Hancock Mutual Life, ${ }^{303}$ Justice Thomas's dissent mixes attention to the text with attention to the realities of its administration. Regarding the text, his principal argument is holistic, although motivated by a generally conservative attitude toward the exercise of rulemaking power. The relevant language just does not read like a rule; although appearing in CFR, it is an explanatory "preamble," "cast in vague, aspirational terms," not a statement of propositions that bind. ${ }^{304}$ Reading the regulatory language as a whole, that assessment is a commanding one. ${ }^{305}$ And it is reinforced by Justice Thomas's strong preference for definitive legislative acts:

It is perfectly understandable, of course, for an agency to issue vague regulations, because to do so maximizes agency power and allows the agency greater latitude to make law through adjudication rather than through the more cumbersome rule-

\footnotetext{
${ }^{301}$ Educational Activities. Many providers engage in educational activities including training programs for nurses, medical students, interns and residents, and various paramedical specialties. These programs contribute to the quality of patient care within an institution and are necessary to meet the community's needs for medical and paramedical personnel. It is recognized that the costs of such educational activities should be borne by the community. However, many communities have not assumed responsibility for financing these programs and it is necessary that support be provided by those purchasing health care. Until communities undertake to bear these costs, the [Medicare] program will participate appropriately in the support of these activities. Although the intent of the program is to share in the support of educational activities customarily or traditionally carried on by providers in conjunction with their operations, it is not intended that this program should participate in increased costs resulting from redistribution of costs from educational institutions or units to patient care institutions or units.
}

42 CFR § $413.85(c)$.

${ }^{302}$ Compare the different approach the majority took in Greenwicb Collieries, disussed at page 487.

${ }^{303}$ Discussed in text following p 519.

${ }^{304} 114 \mathrm{~S} \mathrm{Ct}$ at 2390.

${ }^{305}$ See note 301 ; the precise language in issue in the case is the last sentence of the quoted material. 
making process. Nonetheless, agency rules should be clear and definite so that affected parties will have adequate notice concerning the agency's understanding of the law. ${ }^{306}$

"The agency has to say it clearly" resonates strongly with "Congress must say what it means; I won't look outside the text."

Justice Thomas also asserted that during the first two decades of its administration the Secretary had in fact treated his regulation as merely precatory. Its application here only served to prevent Jefferson from changing its accounting practices to conform to practices that regularly (and properly) produced reimbursement for other teaching hospitals. Here, then, Justice Thomas focused upon the actual administration and understanding respecting the Secretary's rules over time-how they seem to have been understood in the community to which they applied, what would be the practical implications of one or the other reading. As he did in Jobn Hancock Mutual Life, he attaches importance here to the element of continuity in actual administration, as providing proper insight into possible meaning. That contextual element is more often missing from his address to statutory issues, and marks the most frequent divide between Justice Stevens and himself.

\section{Conclusion}

This somewhat discursive review of the Court's work during the Term suggests that a majority of Justices, not invariably but consistently, took an essentially static and oppositional view of the task of statutory interpretation. Justices Scalia, Kennedy, and Thomas most directly, and the Chief Justice and Justice O'Connor often, tended to treat statutes as the one-time pronouncements of an independent Congress - binding so far as they imposed a meaning, but not instructive, not illuminated either by their political history or by the course of their implementation, not an invitation to judicial partnership. They seem to imagine that legislature, agencies, and courts work in isolation, as if uninformed in their own judgments by the work the others are doing and their constant, overseeing, and responsive presence. This approach reverses understandings that long predate the New Deal, about the need to

\footnotetext{
${ }^{306}$ Citing the Davis and Pierce Administrative Law Treatise in a passage making a strong quasi-delegation argument for this proposition.
} 
accommodate the growth of statutes and administration as sources of law. It resegregates the worlds of statute and common law.

The Court was not constant in this; Hawaiian Airlines ${ }^{307}$ coexisted with Greenwich Collieries. ${ }^{308}$ Perhaps we have little to learn beyond the realist bromide that only results, not reasons, count. ${ }^{309}$ Or perhaps the inconstancy is a function of judicial personality. Professor Merrill has suggested that the appearance of change in the Court's reasoning may be the result of consistent attention to the matter by only two of the Justices, Justice Scalia and Justice Thomas, who by attaching importance to methodological issues other Justices find secondary make it appear their views are more widely insisted upon than in fact they are. ${ }^{310}$ Justice Blackmun, who wrote Hawaiian Airlines, was more likely than most to take integrative approaches; in a unanimous matter near the Term's end, when the most difficult controversies also remained to be resolved, the Justices may have had less time for careful scrutiny of reasoning to a result on which all had agreed. Or, possibly, we should be looking past the Justices to their law clerks; inconstancy in the intellectual premises of the Court's work may be evidence that its thirty-odd young and transient law clerks control [too] much of its workproduct. The lawyers too may bear some responsibility. Arguments do not come to the Justices perfectly shaped in each case; how particular cases are briefed and argued will influence the outcomes. Widely varying styles of advocacy (which would be encouraged by unpredictability in the intellectual premises on which the Justices appear to approach their work) both evidence and serve to enlarge the extent to which lawyering has lost a grounding in shared traditions of understanding and technique.

Yet any such "explanation" insufficiently credits, in my judgment, the seriousness with which the separatist position was, again and again, advanced. Often stated as a position about the function of Congress - what judicial approach is necessary to preserve Congress's assigned responsibilities under the constitutional separation

\footnotetext{
${ }^{307}$ Discussed in text following p 490.

${ }^{308}$ Discussed in text following $\mathrm{p} 486$.

${ }^{309}$ Compare Frank H. Easterbrook, Ways of Criticizing the Court, 95 Harv L Rev 802 (1982).

${ }^{310}$ Merrill, work cited in n 41, 72 Wash U L Q at 365. In my judgment, Justice Kennedy is also persistent in emphasizing the gulf between the worlds of statute and court-the wrongness of courts taking responsibility for what is Congress's to provide.
} 
of powers-it is equally (and inevitably) a position about the function of being a court. Five years ago, writing for himself, the Chief Justice, and Justice O'Connor, ${ }^{311}$ Justice Kennedy had justified his general reluctance to consult legislative history in terms of the constitutional separation of powers; the strength of his view is demonstrated by its consequence, that he then had to decide a constitutional issue adversely to the statute. ${ }^{312}$ To use legislative history to give a statute meaning beyond what its language could bear, he argued,

creates too great a risk that the Court is exercising its own "WILL instead of JUDGMENT," with the consequence of "substituti[ng] [its own] pleasure to that of the legislative body." The Federalist No. 78, p. 469 (C. Rossiter ed. 1961) (A. Hamilton). . . .

... Where it is clear that the unambiguous language of a statute embraces certain conduct, and it would not be patently absurd to apply the statute to such conduct, it does not foster a democratic exegesis for this Court to rummage through unauthoritative materials to consult the spirit of the legislation in order to discover an alternative interpretation of the statute with which the Court is more comfortable. ${ }^{313}$

In this Term's cases, similar reasoning has been used to reject meanings that statutory language could bear (and meanings that for a time may have prevailed) but that the majority found unpersuasive, ${ }^{314}$ and to reject judicial gap-filling in cases that were not directly provided for by a statute but that fall within stable expectations past precedents have promoted about its application. ${ }^{315}$ The

\footnotetext{
${ }^{311}$ Justice Scalia was not participating in the case; Justice Thomas had not yet joined the Court.

${ }^{312}$ Public Citizen v U.S. Department of Justice, 491 US 440 (1989). The avoidance of a constitutional question, particularly when one's judgment will be to find against constitutionality, has long been promoted by the Justices and influntial commentators, as a means of preventing unnecessary friction between the branches. See, e.g., Asbwander v TVA, 297 US 288, 341 (1936) (Brandeis concurring); Alexander M. Bickel, The Least Dangerous Branch (1962).

${ }^{313} 491$ US at $471-73$.

${ }^{314}$ For example, BFP, discussed at p 449; Shannon, discussed at p 471; Greenwich Collieries, discussed at $\mathrm{p}$ 486; Healtb Care and Retirement Corp., discussed at p 513; MCI Telecommunications Corp., discussed at p 493; City of Chicago, discussed at $\mathrm{p} 499$.

${ }^{315}$ E.g., Gotshall, discussed at p 429; Holder, discussed at p 464; Central Bank of Denver, discussed at $\mathrm{p} 509$. The concurrence in Rivers and Landgraf, discussed at p 457, is to similar effect.
} 
Court's responsibility for separation of powers, the argument appears to be, reaches beyond the legislative history dispute. It requires the Court to promote congressional accountability for political judgments-and that means requiring Congress to make those judgments-at whatever cost to supportive collaboration between Congress and the courts.

A similar but more limited argument has long been made in support of the proposition cast aside with surprising ease in Greenwich Collieries ${ }^{316}$ and, in effect, Central Bank of Denver, ${ }^{317}$ that protection of congressional function requires the courts not to revisit statutory constructions once established. In 1948, for example, Edward Levi argued in his Introduction to Legal Reasoning that for courts freely to "reinterpret legislation" ${ }^{18}$ would sap Congress's political responsibility.

If legislation which is disfavored can be interpreted away from time to time, then it is not to be expected, particularly if controversy is high, that the legislature will ever act. ${ }^{319}$

For Levi, however, this argument is addressed to second looks, not first ones. In the initial filling of the gap that legislation (like all use of language) inevitably leaves, Levi intends that the courts must be sympathetic to legislative purposes; "[l]egislatures and courts are cooperative lawmaking bodies." 320 That initial interpretation will set the course for the legislation; its legitimacy depends on the courts' sympathy for the democratic impulse underlying Congress's action. But

[i]f the court is to have freedom to reinterpret legislation, the result will be to relieve the legislature from pressure. The legislation needs judicial consistency. . . . [O]nce a decisive interpretation of legislative intent has been made, and in that sense a direction has been fixed within the gap of ambiguity, the court should take that direction as given. ${ }^{321}$

\footnotetext{
${ }^{316}$ Discussed in text following $\mathrm{p} 488$.

${ }^{317}$ Discussed in text following $\mathrm{p} 511$. In effect because, as the majority would not consider, the interpretation had become so well established in the lower courts, over such an extensive period.

${ }^{318}$ At 23 (emphasis added).

${ }^{319}$ Id.

${ }^{320} \mathrm{Id}$.

${ }^{321} \mathrm{Id}$.
} 
To put this another way, and generalize the argument somewhat, the "pressure" Levi is referring to appears to be pressure to move the law from some existing community understanding of it. Once it is established what legislatively created law "is" in community regard, Congress should be responsible for changing that, not the courts. But we can see, too, that this establishment can occur without the intervention of the Supreme Court-indeed, given the enormous level of judicial (and agency) business, and the very limited resources available to the Court, this is inevitable. ${ }^{322}$ Interpretations may have become thoroughly settled in the community, the "direction . . . fixed within the gap of ambiguity," long before the Court, with its one hundred or so yearly occasions for pronouncement, reaches a matter. Even if the Court is formally free to adopt a different interpretation, because it has never before considered the issue, the direction may be so clearly set that a contrary reading would be confrontational, and inconsistent with the primary legislative responsibility for change. Just as the accretion of lower court experience presages change in the common law, a gathering body of lower court or agency interpretation, under the gaze of a responsible legislature, fixes a context of community understanding from which the Court cannot depart without raising questions of democracy. ${ }^{323} \mathrm{It}$, too, may set a baseline of understanding that Congress has the responsibility to vary.

Preserving legislative responsibility also animates arguments about delegation, and thus about how ready courts should be to find that statutes present a "gap of ambiguity" they can fill. If, rather than voice policy directions, legislatures enact vacuous formulas that leave essential choices to others, shouldn't courts refuse that responsibility and find means to require the legislatures to act? Even conceding the argument, of course, requires some sensitivity to the question whether or in what respects a legislature has failed to decide in a particular instance-a question that cannot be answered by resort to artificial rules about the use of language without, again, placing the courts into possible conflict with the legislature. As Daniel Farber has persuasively remarked, this formal approach "contrasts with normal methods of communication,

\footnotetext{
322 Strauss, work cited at n 232.

${ }^{323}$ See Cammarano $v$ United States, 358 US 498, 508-11 (1959) (IRS interpretations of tax law issue in effect adopted through congressional oversight process).
} 
which assume a cooperative listener." ${ }^{324}$ If one can know the judgments that underlay a statute from its political history and other indicators, a decision based on formal failure to include a particular word in an operative list seems at best pedantic, at worst a symptom of struggle and uncooperativeness. ${ }^{325}$ The inquiry whether Congress has in fact decided a matter, that is, may itself be a political one, animated by an unwillingness to find a certain kind of result; and when it is, the problem is not that Congress has failed to fulfill its appropriate function.

Principles of interpretation have often been defended in terms of their instructive possibilities, but the appropriate premises and limitations of judicial instruction of Congress should be kept in view. The very idea of instructing or teaching Congress suggests a hierarchical view quite inappropriate to a government of co-equal branches. ${ }^{326}$ In a democratic society, moreover, one would anticipate premises generally supportive rather than destructive of the legislative enterprise. Levi's arguments do not suppose or seek to justify a general judicial attitude of unfriendliness toward the work of the legislature. His argument is one about the conditions most conducive to social peace, and is premised on the understanding that

[n]ot only do new situations arise, but in addition peoples' wants change. The categories used in the legal process must be left ambiguous in order to permit the infusion of new ideas. ... [T] he laws come to express the ideas of the community, and even when written in general terms, in statute or constitution, are molded to the specific case. ${ }^{327}$

The dialogue he seeks is one supposed to respect democratic values; it is not an argument for the superiority of the common law but supposes as a general endeavor judicial and legislative cooperation toward the community's preferences.

Levi, writing in 1948, assumes that the legislature speaks with a legitimately democratic voice, that its claim to having its judgments

\footnotetext{
${ }^{324}$ Daniel A. Farber, The Inevitability of Practical Reason: Statutes, Formalism and the Rule of Law, 45 Vand L Rev 533, 551 (1992).

${ }^{325}$ City of Cbicago, discussed at $\mathrm{p} 501$.

${ }^{326}$ See also T. Alexander Aleinikoff, Updating Statutory Interpretation, 87 Mich L Rev 20, 31-32 (1988); Farber, 45 Vand L Rev at 549 n 89 and 551 (cited in note 324).

${ }^{327}$ Levi at 4 .
} 
respected and implemented is that it utters the voice of the people in some broad sense. Both a large body of recent scholarly literature and enduring themes of contemporary politics raise difficult questions about the accuracy of that claim. ${ }^{328}$ Should the courts agree with this broadly held perception that Congress has been captured by "faction," would that warrant their refusal to cooperate? One steps here well past the Carolene Products propositions that support unusual judicial interventions into politics on the ground that they may serve to unblock the political process. ${ }^{329}$ While one sees how measures protective of speech or responsive to malapportionment may serve to reinvigorate political branches themselves blocked from self-reform, it is unclear how restrictive judicial attitudes toward legislation in general would tend to make Congress more representative. Indeed, the very fact of reasoning in this way would offend central values of the Constitution, which imagine the branches as coordinate; would appear like posing as Congress's teacher. To thus judge Congress's capacity for action is to raise a political question in the classic sense adumbrated by Baker $v$ Carr ${ }^{330}$ "expressing lack of the respect due coordinate branches of government." "331

Moreover, the argument presupposes that the courts would somehow remain outside politics in a government otherwise dominated by factional excess. Neither our history nor political theory warrant any such claim. ${ }^{332}$ It was Progressive legislation enacted by new majorities on behalf of the formerly oppressed that excited judicial resistance at the turn of the century-legislation easing the obstacles to recovery for injuries suffered in the workplace, or protecting workers from unsafe or unhealthy working conditions. More recently, the Supreme Court's narrow interpretations have

\footnotetext{
${ }^{328}$ For example, Daniel A. Farber and Philip P. Frickey, Law and Public Cboice (Chicago, 1991); Symposium: Regulating Regulation: The Political Economy of Administrative Procedures and Regulatory Instruments, 57 L \& Contemp Probs 1 (1994); Symposium: Positive Political Theory and Public Law, 80 Georgetown L J 457 and 1737 (1992); Symposium: The New Public Law, 89 Mich L Rev 707 (1991).

${ }^{329}$ United States $v$ Carolene Products Corp., 304 US 144, 152-53 n 4 (1938); see, e.g., John Hart Ely, Democracy and Distrust (1980).

$330369 \mathrm{US}$ at $186(1962)$.

${ }^{331}$ Id at 210.

${ }^{332}$ See Edward L. Rubin, Public Cboice in Practice and Theory, 81 Cal L Rev 1657 (1993); Daniel Shaviro, Beyond Public Cboice and Public Interest: A Study of the Legislative Process and Illustrated by Tax Legislation in the 1980s, $139 \mathrm{U}$ Pa L Rev 1, 65-68 (1990).
} 
been visited upon legislation that expanded civil rights, provided for consumer protection, and protected bankrupts' estates. While one certainly knows that Congress sometimes enacts special interest legislation, it is hard to see these particular measures as reflecting chiefly the interests of the politically powerful. That characterization is much more easily attached to the judicial results. ${ }^{333}$ In any competition for political legitimacy in putting into effect their political views, the judiciary has long understood, as the people have, that it comes last among the branches.

Taking seriously the separation of powers argument requires attention to an aspect that its proponents have not much discussed, but that seems implicit in some of the cases discussed in this essay: namely, what is entailed in being a "court." It is not only Congress that has a constitutional function; so does the federal judiciary. Separation of powers reasoning about Congress's role cannot properly be taken so far as to deny to the judiciary the quality and responsibility of courts. In particular, the argument here supposes the legitimacy of federal courts' common law function-that is, that it is sometimes appropriate for them to develop the law outside the realm of statutes, exercising authority of the character traditional to the English courts and to state judicial systems. That is what permits us to ask why they should do any less in the statutory context-indeed, whether they have a higher obligation to observe legislative signals as the source of policy, than their own prior reasoning.

A common law court cannot persuasively invoke, as a reason why courts should not fill out what Congress has not directly expressed, the proposition that lawmaking is only for Congress. ${ }^{334}$

${ }^{333}$ Aleinikoff, 87 Mich L Rev at 32, cited in note 29, considers whether formalist techniques are warranted to discipline otherwise over-adventurous "intentionalist" judges, rather than to instruct the legislature.

But if the instances of bad-faith judging are so great that the plain meaning theorists are comfortable in their calculation, one wonders why the legislature (which after all is the injured party) hasn't taken steps to reduce bad-faith judging by writing statutes more clearly. Furthermore, if we assume such a plethora of willful judges, why should we believe that they will not similarly misuse a plain meaning approach?

If one looks to recent cases in which Congress has corrected judicial "error," as in the civil rights area, those opinions have been predominantly formalist, not intentionalist, in character. See also William N. Eskridge, Jr., Reneging on History? Playing the Court/Congress/President Civil Rights Game, 79 Cal L Rev 613, 675-80 (1991).

${ }^{334}$ This formalist argument was among those earlier and persuasively addressed in William N. Eskridge, Jr., Dynamic Statutory Interpretation, 135 U Pa L Rev 1479, 1497 ff (1987), 
To the extent that argument depends on a wholly formal view of judicial function-the idea that judges find but do not make law-it is indistinguishable from, and no more credible than, the similar argument once made about the common law function. City of Cbicago $0^{335}$ and $B_{F P} P^{336}$ are good illustrations of the point. Outside the sphere of legislation, we readily see that judicial disclaimers of lawmaking are disingenuous or, at best, metaphors for the appropriateness of restraint in that function. ${ }^{337}$

It is important that the mechanism of legal reasoning should not be concealed by its pretense. The pretense is that the law is a system of known rules applied by a judge; the pretense has long been under attack. In an important sense legal rules are never clear, and if a rule had to be clear before it could be imposed, society would be impossible. The mechanism accepts the differences of view and ambiguities of words. It provides for the participation of the community in resolving the ambiguity by providing a forum for the discussion of policy in the gap of ambiguity. On serious controversial questions, it makes it possible to take the first step in the direction of what otherwise would be forbidden ends. The mechanism is indispensable to peace in a community. ${ }^{338}$

So long as this is what judges are doing-as in the common law context-then building upon the political judgments expressed in legislation would seem, ceteris paribus, to improve the chances that the judges' inevitable resolution of "policy in the gap of ambiguity" would conform to society's wishes and thus tend toward "peace in [the] community." Indeed, this proposition lies at the heart of the arguments of Pound and Stone with which, in a sense, this article began. ${ }^{339}$ When Pound wrote, the courts customarily elevated their common law functions over statutes, preferring the policies of the common law to the policies of statutes; the result of this self-evident struggle with state and federal legislatures was to submerge the views of the community in resolving "policy in the [inevitable] gap of

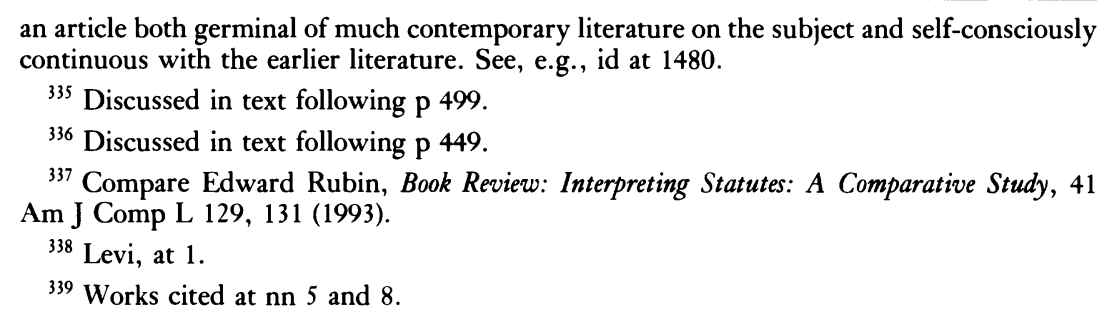


ambiguity," rather than to foster its expression. Judicial behavior was in this way destructive, not supportive, of social peace. It defeated rather than supported principles of accountability. ${ }^{340}$

If we were to conclude that the federal courts were not courts in this sense, then much of the preceding argument would be undercut. The Constitution, its foundational documents, and early federal judicial practice are all instinct with the understanding that the federal courts were to be courts as the English colonists and then the citizens of the states had experienced courts. ${ }^{341}$ In areas of undoubted federal jurisdiction, such as admiralty, they have always acted as courts in the full Anglo-American sense. To be sure, Erie R. Co. $v$ Tompkins $^{342}$ stands for the proposition that federal courts lack competence to generate common law independent of relevant state law in the diversity jurisdiction. ${ }^{343}$ But that is an artifact of diversity jurisdiction, which depends on the character of the parties and assumes state law will apply. Extending that conclusion to federal question jurisdiction would be a stunning revision of constitutional understandings; it would convert the federal courts into instruments genuinely foreign to American legal traditions. $^{344}$

Perhaps there are other ways of perceiving the occasional indica-

${ }^{340}$ To Robert Gross I owe the observation that the only actors accountable for interpretations driven by dictionaries may be their commercial publishers. The decisions legislatures actually make, as the public knows them, are not implemented. The decisions judges make are, at least ostensibly, not their own. See Muriel M. Spence, The Sleeping Giant: Textualism as Power Struggle, 67 So Cal L Rev 585 (1994).

${ }^{341}$ Compare the evocation of judicial function in David A. Strauss, Common Law Constitutional Interpretation (unpublished).

342304 US 64 (1938).

${ }^{343}$ In this respect, its overruling of Swift $v$ Tyson, 41 US 1 (1842), depends on a reading of Swift not obvious at the time it was decided, that it resolved an issue not within federal question jurisdiction. The Swift Court's broad insistence on the importance of uniform rules for the protection of commerce, 41 US at 18-19, might instead have been understood to invoke the federal jurisdiction over interstate commerce. One can imagine objections to invoking the Constitution in support of a necessarily federal rule; but the argument that federal courts have power to generate common law supportive of federal authority is indistinguishable in principle from the argument that they may generate principles of admiralty. Compare Thomas W. Merrill, The Common Law Powers of Federal Courts, 52 U Chi L Rev $1,30,64-65$ and $\mathrm{n} 279$ (1985).

344 Thomas Merrill develops such an argument at length in the work cited in the immediately preceding note; he seems to concede, however, the bearing of the framers' expectation that the federal judiciary would be "courts." Id at 65 n 279; his essay is strongly criticized in William N. Eskridge, Jr., Dynamic Statutory Interpretation, 135 U Pa L Rev 1479, 14981501 (1987). 
tions from some Justices that the Supreme Court is not a fully fledged common law court, even for federal question purposes. Might dependency on state court definitions of common law doctrine be justified on grounds of their relatively greater expertise, as they encounter such questions more often? Or as an unspoken balancing factor, given the enormity of the federal constitutional and statutory authority over the content of law for the states? Or as a reflection that the Court, with other arguably more important and in any event more distinctively federal tasks to accomplish, is simply not very adept at this function, and should not try to do it for itself? While a certain reality underlies these speculations, what also underlies them is, again, a rather aconstitutional vision of what it means to be a court in American legal culture. It may be so, in some sense, that constitutional cases are the most important element in the Court's docket, but it is nonetheless an ordinary court in our Constitution's contemplation-not a constitutional court or an administrative court, such as characterize some European systems. Indeed, we tend to think its legitimacy importantly derives from its conventional judicial function. We cannot, then, afford to let the character of its docket defeat its characteristics, without changing our Constitution. Moreover, even if the Supreme Court is in some factual sense relatively removed from ordinary judging, the lower federal courts are not. They have a steady diet of common law questions, both in the diversity jurisdiction and in the federal question jurisdiction. And the same positivistic view of the common law that underlies Erie-that it is simply the judge-made law of a particular political jurisdiction-makes it unthinkable that, as to federal questions, federal common law should be parasitic on state court choices. In making federal common law, where it is appropriate to do so, the federal courts can no more be limited by what California and North Carolina courts have chosen for their jurisdictions than are the courts of Minnesota.

Perhaps there is a sense in which this is all quite unconscious. One characteristic of formalism, often enough noted, is that it permits judges to claim - to themselves as well as to others-that they can always make decisions without drawing on their own ideas of good policy or social justice. It externalizes responsibility. Even to Justices who learned too well that formation of the common law does not work that way, common law rules can provide a similar refuge from responsibility, if they can be made to come from some- 
place else. One no longer entertains the possibility of a single source in the heavens; but the Erie idea that the state courts are the necessary source in matters of diversity jurisdiction (because the questions there are questions of state law) is easily and perhaps unconsciously transmogrified into a more general responsibility. The common law now comes from out there, if not up there. Its federal character in these cases, and the Court's consequent responsibility for the choices that shape it, is simply ignored. Here, as in dealing with legislation by dictionary, the Court will have escaped its own responsibility. ${ }^{345}$

From a certain perspective, the risk of judicial politics is present, whichever approach the Justices take. In whatever fashion the Justices may interpret a statute, Congress can change that interpretation only by the concurrence of two houses and (in the usual case) acquiescence by the then President. As Professors Eskridge and Ferejohn, among others, have shown us, that in effect means that the judiciary can effectively put into place any interpretation Congress will be unable to change-a considerable degree of freedom of maneuver. ${ }^{346}$ Even if we assume a cooperative process between courts and legislature, judicial "mistakes" will inevitably occur; but they will be mistakes made despite a posture of concern for congressional political judgment and attention to community expectations. That is the apparent story of the differences between the vetoed Civil Rights Act Amendments of 1990 and the enacted Civil Rights Act Amendments of 1991 that gave rise to the problem in Rivers and Landgraf. ${ }^{347}$ To assert that the Constitution requires that the Congress and the Court not be cooperators, however - that the courts are obliged to honor only those instructions that are unmistakable on the "objective" surface of the text-is to free the Court of any such posture, its tools limited to the manipulable world of the text. ${ }^{348}$ Thus one sees how the insistence on the static quality of legislation, which only Congress can correct, not only denies responsibilities for cooperation, but also plays into a rather cynically political game.

\footnotetext{
${ }^{345}$ See note 340 .

${ }^{346}$ William N. Eskridge, Jr., and John Ferejohn, The Article I, Section 7 Game, 80 Georgetown L J 523 (1992).

${ }^{347}$ Discussed in text following $\mathrm{p} 454$.

${ }^{348}$ Merrill, work cited in $\mathrm{n} 41$.
} 
Whatever its source, the emerging view of judging and judges' place in the political order is not only profoundly altered from that which has generally characterized our polity; it also portends rigidity and destabilization for law and its administration. The constant rising and resolution of issues through the judicial system has been a means by which law continually refits itself to social needs, reducing to that extent the need for constant legislating. Clearly enough judges sometimes err, and legislatures may then correct; or the judiciary fails to accommodate the law quickly enough to changing social circumstances and, again, legislation may do so. But the premise that legitimate change occurs only legislatively puts under constant threat all those understandings that inevitably arise-are acted upon and relied upon-in its wake. The Supreme Court hears the smallest proportion of the cases resolved by the federal system each year; its interventions are made necessarily episodic by that fact. If its task in dealing with statutes is to enforce original understandings as a majority of Justices come to see them, regardless what developments may have occurred in the interim, the prospect is more, not less, uncertainty; and this impact is heightened if the Court, in so acting, is also unwilling to educate itself about the political context within which Congress has acted-elevating, in that way, the chances of conflict over political judgments Congress has reached.

It is hard to believe that the result of this struggle will be improved performance by the legislature. First, legislation for other reasons is already assuming proportions too large for the more careful drafting the Court ostensibly invites; second, if history is any guide, the only outcome to be anticipated from the Court's formal and distant approach is a larger rather than a smaller volume of specification from the legislature. ${ }^{349}$ Finally, and perhaps most important, even if we can imagine Congress learning from its dialog with the Court, the lesson is in one large measure perverse: While the Court says that it is contributing to settled expectations, that can be so only for legislation written in response to its opinions about interpretation, after those opinions have been written. But earlier legislation was written in the context of other interpretive

\footnotetext{
${ }^{349}$ Lieber, work cited in n 33. A similar argument appears in modern dress in Edward P. Schwartz, Pablo T. Spiller, and Santiago Urbiztondo, A Positive Theory of Legislative Intent, 57 L \& Contemp Probs 51 (1994).
} 
expectations. By failing to honor the interpretive expectations that governed Congress's action when the earlier statutes were passed, the Court teaches that today's lessons have no necessary relevance to the style of interpretation the Court will use tomorrow.

The Justices are changing the premises of our system, and not for the better. Perhaps, they will say, it is to correct for an excessively powerful view the prior generation of Justices held; but the act of deconstruction is powerful and destructive-and its premises quite outside what had until now been the shared political premises of a common law system of judging. 